Andrews University

Digital Commons @ Andrews University

2005

\title{
A Pilot Grief Ministry Program To Equip Grief Ministry Facilitators in the Local Adventist Churches
}

Joyce Marie Hatchett

Andrews University

Follow this and additional works at: https://digitalcommons.andrews.edu/dmin

Part of the Practical Theology Commons

\section{Recommended Citation}

Hatchett, Joyce Marie, "A Pilot Grief Ministry Program To Equip Grief Ministry Facilitators in the Local Adventist Churches" (2005). Professional Dissertations DMin. 482.

https://dx.doi.org/10.32597/dmin/482

https://digitalcommons.andrews.edu/dmin/482

This Project Report is brought to you for free and open access by the Graduate Research at Digital Commons @ Andrews University. It has been accepted for inclusion in Professional Dissertations DMin by an authorized administrator of Digital Commons @ Andrews University. For more information, please contact repository@andrews.edu. 


\begin{abstract}
A PILOT GRIEF MINISTRY PROGRAM TO EQUIP GRIEF MINISTRY FACILITATORS IN THE

LOCAL ADVENTIST CHURCHES
\end{abstract}

\author{
by \\ Joyce Marie Hatchett
}

Adviser: James J. North, Jr. 


\title{
ABSTRACT OF GRADUATE STUDENT RESEARCH
}

\author{
Dissertation \\ Andrews University \\ Seventh-day Adventist Theological Seminary
}

Title: A PILOT GRIEF MINISTRY PROGRAM TO EQUIP GRIEF MINISTRY FACILITATORS IN THE LOCAL ADVENTIST CHURCH

Name of researcher: Joyce Marie Hatchett

Name and degree of faculty adviser: James J. North, Jr., D.Min.

Date completed: December 2005

Problem

There is a need for a visible and effective Seventh-day Adventist Grief Ministry Training Program that is theologically sound and culturally sensitive that will serve the bereavement needs of both the local Seventh-day Adventist congregation(s) and others in the community.

\section{Method}

For this study, I used formative evaluation, sometimes referred to as pilot testing. Formative Evaluation has two goals: (1) To gain understanding through observation and soliciting responses of participants concerning how the curriculum and instructional 
processes might be improved; and (2) to develop strategies for improving the curriculum and instructional process.

This pilot training program was held September 5-7, 2003, in the Seventh-day Adventist Theological Seminary, Room 150, at Andrews University, Berrien Springs, Michigan. Twelve Seventh-day Adventists participated in this pilot program. Six were from campus housing and six were from local communities.

\section{Results}

Grief Ministry is vital for the faith community and provides several options for consideration to the individual or family that find themselves in need of this service after the death of a loved one. These comments from the participants were affirming. "It addressed my personal needs." "It addressed relevant issues." "The handouts and assignments given were very helpful." "It promoted healing and I believe that it helped me to be in a better place."

The seminar was very encouraging as I witnessed the mental and emotional healing of the participants as they did their individual grief work. We all grew spiritually and experienced the physical strength that comes from intentionally allowing God to be a part of the grieving process.

\section{Conclusions}

Based on the presentations, observations, and discussions with participants, the seminar met its goal. It provided a model that can and will be improved upon. The conclusions and recommendations will be systematically implemented and evaluated in future training programs in an effort to refine the ministry. 


\title{
Andrews University
}

Seventh-day Adventist Theological Seminary

\section{A PILOT GRIEF MINISTRY PROGRAM TO EQUIP GRIEF MINISTRY FACILITATORS IN THE LOCAL ADVENTIST CHURCHES}

\author{
A Dissertation \\ Presented in Partial Fulfillment \\ of the Requirements for the Degree \\ Doctor of Ministry
}

by

Joyce Marie Hatchett

December 2005 



\title{
A PILOT GRIEF MINISTRY PROGRAM TO EQUIP GRIEF MINISTRY FACILITATORS IN THE LOCAL ADVENTIST CHURCHES
}

\author{
A dissertation \\ presented in partial fulfillment \\ of the requirements for the degree \\ Doctor of Ministry
}

by

Joyce Marie Hatchett

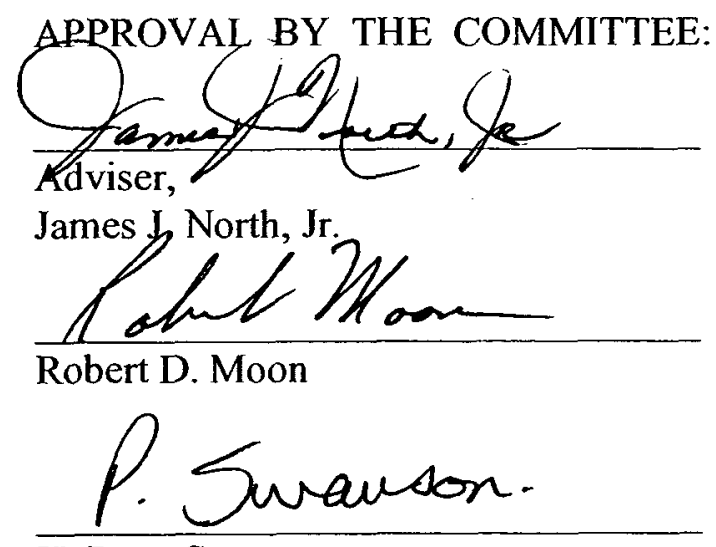

H. Peter Swanson

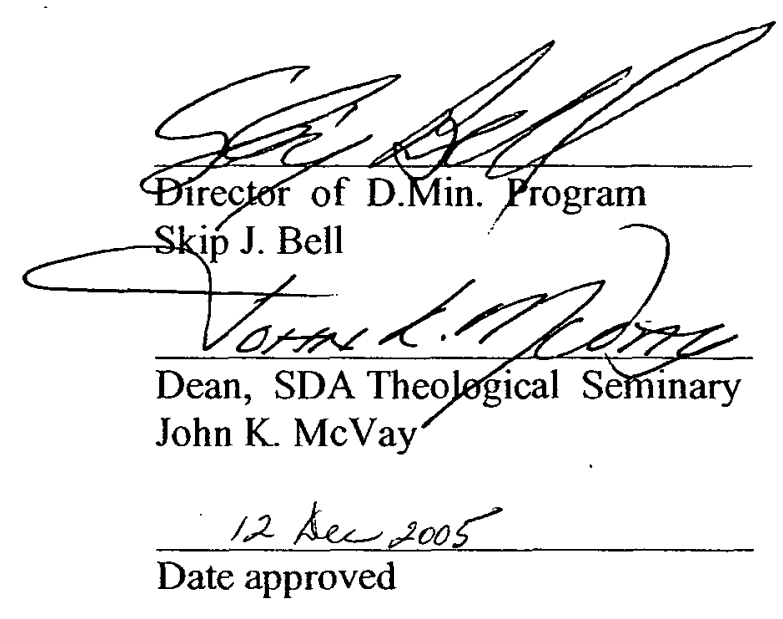




\section{TABLE OF CONTENTS}

LIST OF TABLES

Chapter

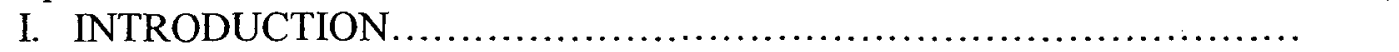

Statement of the Problem ....................................... 1

Statement of the Task .............................................

Justification for the Dissertation ................................ 1

Description of the Dissertation ................................... 3

Limitations of the Dissertation ................................... 5

Methodology ...................................................... 5

Definition of Grief Terms ..................................... 7

Definition of Biblical Terms Related to Grieving ................... 12

Additional Information Regarding Biblical Definitions .............. 14

Literature Review .......................................... 16

The Expectations from This Dissertation ........................ 25

II. A BIBILICAL APPROACH TO GRIEF MINISTRY .................... 27

An Old Testament Approach to Grief

Jacob's Grief for Joseph (Genesis) ........................ 28

A New Testament Approach to Grief: Death

And Resurrection of Lazanus ............................ 33

God's Eternal Approach to Grief Ministry ....................... 37

The First Gift-Reconciliation ......................... 37

The Second Gift-The Resurrection ....................... 38

The Third Gift-Eternal Life ............................. $\quad 39$

The Fourth Gift-Immortality ............................ 39

A Biblical Role Model-Abraham ............................ 42

From the Oaks of Moreh to the Hill Country ................ 43

Famine, Sojourn to Egypt, and Sarah in Pharaoh's Harem .................................. 44

Separation from Lot, War, and Rescue ................... $\quad 45$

Abraham Faces His Mortality and the

Covenant Relationship ........................... 46

Hagar's Marriage, Flight, and

the Birth of Ishmael ................................. 48

Abraham Bargains with God over Sodom ................. 48 
Abimelech's Court, the Birth of Issac,

Hagar and Ishmael Sent Away ....................... 50

Isaac on Mount Moriah, and Sarah's Death .................. 51

Isaac's Marriage, Abraham's Remarriage,

and Abraham's Death

III. PERSONAL AND COMMUNITY RITUALS

THAT FACILITATE GRIEF

Biblical Ritual That Facilitate Grief - Death of Jacob .............. 55

Spirit of Prophecy Rituals That Facilitate Grief - Death of

John Herbert, Henry Nichols, and James Springer White ...... 61

IV. PROPOSED GRIEF PROGRAM FOR GRIEF FACILITATORS............... 76

Purpose of the Program ............................................. 77

Description of the Program .................................. 78

The Format of the Program .................................... 79

The Participants of the Program ............................... 84

V. EVALUATION AND REFLECTIONS OF THE PROGRAM .................. 86

Program Presentation ......................................... 86

Pre-Program Questionnaire ................................... 87

Post-Program Evaluation by Participants ........................ 94

Reflections .................................................. 97

Friday-September 5, 2003, 7:00 - 9:00 p.m................. 97

Saturday-September 6, 2003, 3 p.m. - 6:00 p.m............. 100

Sunday Morning-September 7, 2005, 9:00 a.m. - 12:00 p.m.... 106

Evaluation by the Presenter ................................ 111

VI. SUMMARY, CONCLUSIONS, AND RECOMMENDATIONS......... 113

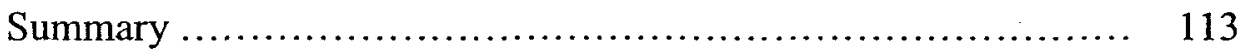

Conclusions and Recommendations ........................... 115

Appendix

A. DEATH OF A LOVED ONE ..................................... 123

B. DEFINITION OF BIBLICAL TERMS ......................... 125

C. A HEALTHY GRIEF PROCESS CHART …..................... 130

D. DR. J. H. KELLOGG'S ACCOUNT OF THE DEATH

OF JAMES S. WHITE ...................................... 132

E. REWARD AND PUNISHMENT AFTER DEATH ............... 135

F. FORGIVE AND FORGET NETWORK, INC ................... 140

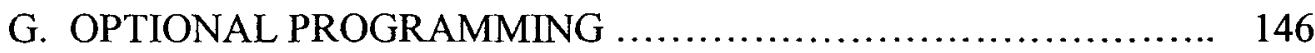


H. DOCTRINE OF LAST THINGS ................................... 151

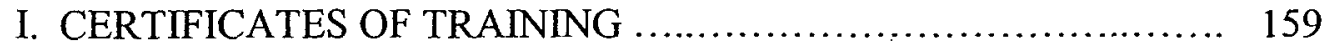

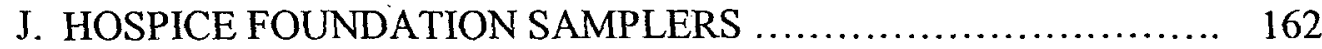

K. GRIEF MINISTRY FACILITATOR'S TRAINING MANUAL ..... 169

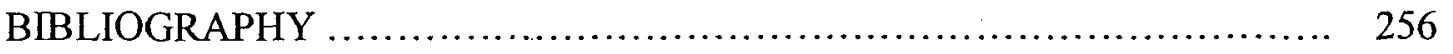




\section{LIST OF TABLES}

1. Demographics ................................................ 88

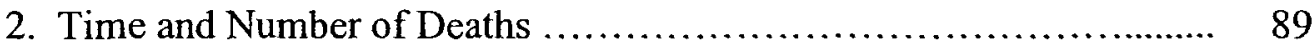

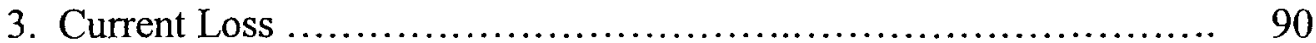

4. Emotional Assessment ...................................... 92

5. Physical Symptoms of My Grief ............................... 93

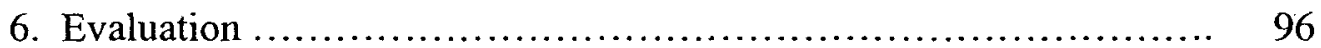


CHAPTER I

INTRODUCTION

\section{Statement of the Problem}

There is a need for a visible and effective Seventh-day Adventist Grief Ministry Training Program that is theologically sound and culturally sensitive that will serve the bereavement needs of both the local Seventh-day Adventist congregation(s) and others in the community.

\section{Statement of the Task}

The purpose of this study was to develop, implement, and evaluate a three-day pilot grief ministry training seminar that will equip participants to become facilitators who can conduct Grief Recovery Programs for the bereaved in local churches.

\section{Justification for the Dissertation}

1. Except for the Grief Recovery Program by Larry Yeagley that originated in the hospital system and is now available through Advent Source, there has not been any other marketed program within the Seventh-day Adventist Church. Additionally, there is no facilitator's training in this area. 
2. The Scripture encourages believers to "rejoice with those who rejoice, weep with those who weep" (Rom 12:15 NRSV); and "not to grieve as others do who have no hope and to encourage one another" (1 Thess 4:13-18 NRSV). In order to effectively do this, we need to have facilitators.

3. Current community grief programs and literature do not address the Seventhday Adventist biblical teaching regarding death. Often non-Adventist grief programs are in conflict with Adventist theology related to the state of the dead. The Seventh-day Adventist theology on the state of the dead can provide a very meaningful and healing dimension. Therefore a training of facilitators needs to include Adventist theology.

4. Bereaved members become confused and disappointed when the church is not able to minister to their needs and they are left to seek healing on their own. This pilot program will enable facilitators to provide comfort and healing (a) within the church community and (b) to the wider community.

5. The church is the only institution that deals with all age levels of humanity from birth to death - dedication/blessing, baptism, marriage, and funeral. As the spiritual community, it addresses and supports the needs of the body of believers. Grief Ministry needs to be included in the spiritual program. Grief affects people all along this spectrum, and facilitators need to be trained to touch people's lives along the birth-todeath spectrum.

6. There is evangelistic potential when non-Adventist family members are able to attend an Adventist Grief Ministry Training Program. Grief Ministry facilitators need to be aware of this as a follow-up potential. Facilitators need to be aware of participants leaning in this direction and point them to appropriate persons. 
7. A facilitator's manual is needed to instruct participants in how to establish grief ministry programs and to provide meaningful ways for believers to strengthen and encourage each other in these traumatic experiences.

\section{Description of the Dissertation}

1. This dissertation makes an assessment of contemporary authors' contributions to grief ministry and grief recovery programs and critiques current personal and community rituals in relation to rituals in the Seventh-day Adventist belief system and culture.

2. It gives an analysis of the biblical stories of Joseph and Lazarus in light of the second coming and future immortality.

3. It examines the events surrounding the death of Jacob (Israel) in the context of the biblical understanding of anticipatory grief, grief, and grief ministry.

4. It observes the life of Abraham as an example of Divinity in relationship to an individual, and community involvement relative to grief.

5. It provides a Grief Ministry Seminar for future grief recovery facilitators.

6. It evaluates and summarizes participants' responses to the seminar.

7. Finally it gives the presenter's opinion of the seminar, the summary and conclusions regarding this seminar and possible future seminars.

Chapter 1 provides an overview of the materials set forth in this dissertation.

Chapter 2 presents three biblical approaches to grief ministry that reflect the pain of grief and the joy of being reunited with loved ones.

1. From the Old Testament there is the story of Jacob and Joseph who were separated for thirty-seven years. Their grief experience of sadness and guilt was based on 
the belief and assumption that death had separated them forever. The life of Abraham is a role model because this is the first biblical knowledge and experience of God's involvement in community with His chosen people.

2. From the New Testament comes the story of the resurrection of Lazarus. Jesus raised Lazarus and reunited him with his family and friends. The grief of the Creator during this event had future applications of Jesus' personal grief experienced during the close of His earthly ministry.

3. God's eternal approach to grief ministry involves the restoration of the intimate relationship between God and humankind through the four gifts-reconciliation, resurrection, eternal life, and immortality - that $\mathrm{He}$ alone can give as an expression of His love at the Second Coming of Jesus Christ.

Chapter 3 provides a foundation for the personal and community rituals that facilitate grief ministry that are currently utilized in the United States. These rituals have been drawn from two sources: (a) The death of Jacob, the father and role model for the twelve tribes of Israel; and (b) Ellen G. White's personal losses shared in her writings.

Chapter 4 presents the pilot Grief Ministry Seminar to equip facilitators to conduct grief recovery programs for the bereaved in the local church and community. Chapter 5 provides the planning and implementation of the program. The results of the seminar are based on the pre- and post-seminar questionnaires. Chapter 6 includes a summary of the seminar, conclusions drawn from the research process, and recommendations for future seminars, program development, and the expansion of grief ministry. 


\section{Limitations of the Dissertation}

There are many life situations and events that can cause grief, such as divorce, marital separation, jail term, personal injury or illness, retirement, sex difficulties, business readjustment, changes in financial status or change in job, etc.; however, the death of a loved one ranks highest on the scale. This dissertation focuses on the death of a loved one.

The common theological teaching relative to the state of the dead is seen by Seventh-day Adventists and some notable theologians as being out of harmony with Scripture. In this dissertation the definition for death is an unconscious sleep.

Many of the personal and community rituals that facilitate grief, discussed in this dissertation, are not universal. They are practiced in Western culture, specifically in the United States with general limitation due to diversity.

This seminar was limited to twelve Seventh-day Adventist participants who responded to the invitation: Three retired lay persons, two social workers, and seven seminarians living in Berrien Springs, Michigan, and the surrounding area. Each of these participants had lost a loved one within the last five years. In one case, a griever in the group lost her mother and father exactly one year apart.

Since there were no non-Adventist participants, only in chapter 3 will there be a comparison of beliefs.

\section{Methodology}

There are two basic approaches to research projects which deal with curriculum and instruction, summative and formative evaluation. For this study, I used formative evaluation, sometimes referred to as pilot testing. Formative evaluation has two goals: 
(1) to gain understanding through observation and solicited responses of participants concerning how the curriculum and instructional processes might be improved; and (2) to develop strategies for improving the curriculum and instructional process as a result of information gained in the pilot testing.'

The overall objective is to develop a grief recovery program for the local SDA Church that would address the wholistic aspects of human behavior - mental, emotional, physical, and spiritual - as they relate to the loss of a loved one. It is my belief that most individuals have within themselves the tools to move toward health and healing; however, the death of the loved one has a tendency to cause them to have some difficulty in drawing on those coping skills because of the intensity of the loss. William Glasser, in his Reality Therapy, deals with the three R's (reality, responsibility, and right-andwrong), makes this observation that has its biblical counterpart, "To do Reality Therapy the therapist must not only be able to help the patient accept the real world, but he must then further help him fulfill his needs in the real world so that he will have no inclination in the future to deny its existence." In his letter to the Philippians, Paul admonishes the believers, "Beloved, I do not consider that I have made it my own; but this I do: forgetting what lies behind and straining forward to what lies ahead, I press on toward the goal for the prize of the heavenly call of God in Christ Jesus" (Phil 3:13, 14).

The targeted participants are divided into four categories: (1) Seventh-day Adventist congregations--primary population; (2) Other Christians-those in the local

\footnotetext{
${ }^{1}$ Benjamin S. Bloom, J. Thomas Hastings, and George F. Madaus, Handbook on Formative and Summative Evaluation of Student Learning (New York: McGraw-Hill, 1971), 117-138. 1965), 5-7.

${ }^{2}$ William Glasser, Reality Therapy: A New Approach to Psychiatry (New York: Harper \& Row,
} 
community; (3) Non-Christians from other Religions-who are seeking grief support; and (4) Those of no religious persuasion-individuals relying on emotional support (Atheist and Agnostics). Recognizing the diversity of these groups the curriculum is set up in such a way that the first three parts of the manual addresses the basic concerns of all those who need grief support. Based on the religious persuasions of participants at a given seminar, adjustments may be made while, at the same time letting them know that the group is Christian oriented.

Appendix $\mathrm{K}$ contains the seminar manual consisting of the literature, illustrations, and exercises used in the Grief Ministry Seminar. The overall plan is to assist individuals in their understanding that when a person enters the grieving process, the grief work must be done by them (the griever or bereaved). The facilitator can only walk along side of the griever as a support or guide. The keys are verbally sharing and utilizing the exercises presented at each session. This allows the griever to face and express their pain relative to the loss of their loved one.

There are six sessions for the training of a facilitator that are covered in six-to eight-hours group sessions (see chapter 4); however the materials and exercises of these sessions can be expanded to meet the needs for a continuous grief recovery program. These sessions do not have to be in a classroom setting. Most of the learning is caught rather than taught.

\section{Definition of Grief Terms}

Some words and phrases in this dissertation will carry the meanings specified below, except where the context clearly modifies the sense of the term. Comments like the one made by Catherine M. Sanders have created some confusion relative to the 
validity of grief terminology: "It should be noted that because of the pain, grief is obscured to the extent that there are few words in our vocabulary to describe it. Four of the most commonly used terms- - bereavement, grief, loss, and mourning —are often used interchangeably; however, because of the broad usage today, the differentiation between them is less important than it used to be." In this paper this differentiation is important and should be noted in the definitions to follow. Consequently it is best to clarify key words and phrases (see Appendix A). For the purpose of this dissertation all the terms are defined as follows.

Acute Grief is the intense pain and confusion that occurs immediately after the death of a loved one. There is somatic distress, preoccupation with the image of the deceased, guilt, hostile reactions, and loss of patterns of conduct. Thomas Attig expresses it this way, "We struggle to find means of overcoming, gaining control of, or constructively expressing and directing our emotions. We work our way through crises in self-identity and disruptions in our usual behavior patterns and develop alternatives. We address and seek to overcome strains in relationships and to build new ones. And we seek ways to make sense of our new reality and to find meanings in life without the deceased."

Anticipatory Grief is "an experience of grief that occurs prior to the death of a loved one and emanates from the expectation of emotional pain and the life changes the

\footnotetext{
${ }^{1}$ Catherine M. Sanders, Grief: The Mourning After; Dealing with Adult Bereavement, 2nd ed. (New York: John Wiley \& Sons, 1999), 4. 1996), 47.

${ }^{2}$ Thomas Attig, How We Grieve: Relearning the World (New York: Oxford University Press,
} 
loss will bring."1 It is generally related to long-term fatal illness when family members know that their loved one is going to die.

Bereavement is the sorrow one experiences when a loved one dies. Bryce $M$. Herkert defines it as "the period of time following a death that an individual grieves or suffers the emotional loss of another person."2 Alicia Skinner Cook and Daniel S. Dworkin characterized it as the general state of being that results from having experienced a significant loss. ${ }^{3}$

Chronic Grief occurs after the death of a loved one and carries the same symptoms as acute grief but over a much longer period of time. "Grief becomes excessive in duration and never comes to a satisfactory conclusion."

Cumulative Grief is when a person experiences several losses so close together that there is no time to recover from one loss before the next one occurs. This can result in unresolved grief. "When one unresolved loss is added to another, recovery from the subsequent death will be extremely torturous, and normally cannot take place until the first loss is healed."5

Death is similar to the state of unconscious sleep but also includes the cessation of life. "Death is not complete annihilation; it is only a state of temporary unconsciousness

\footnotetext{
${ }^{1}$ Alicia Skinner Cook and Daniel S. Dworkin, Helping the Bereaved: Therapeutic Interventions for Children, Adolescents, and Adults (New York: Basic Books, 1992), 21. (2000): 93 .

${ }^{2}$ Bryce M. Herkert, "Communicating Grief," OMEGA: The Journal of Death and Dying 41

${ }^{3}$ Cook and Dworkin, 18.

4 Ibid., 89.

${ }^{5}$ James J. North, Jr., Grief and Loss, http://project-care.org/grief-loss.hmt (July 7, 2004).
} 
while the person awaits the resurrection. The Bible repeatedly calls this intermediate state a sleep."1

Good Grief is kind of an oxymoron that presents the concept that grief is painful but if confronted and dealt with constructively it has good results. It actually can become good grief. Granger E. Westberg states that "good grief is grounded in the basic philosophy that by establishing a relationship with God grievers can face any earthly loss with the knowledge that they still have not lost everything. They still have God on whom to rely. It makes an amazing difference in the quality of the grief experience."2

Grief is the emotional expression of deep sadness, as that caused by bereavement - sorrow. John W. James and Frank Cherry say "grief is the normal and natural reaction to loss of any kind." Doug Manning speaks of grief as "the way we work through loss. It is nature's way of healing a broken heart.".4

To grieve means to feel or respond to grief, to cry out. "Anyone who has personally experienced grief or who has encountered a grieving person will be familiar with the outpouring of feelings that is an essential element of most grief. To grieve well is to value what you have lost. When you value even the feeling of loss, you value life itself, and you begin to live again." ${ }^{5}$

\footnotetext{
${ }^{1}$ General Conference Ministerial Association, Seventh-day Adventists Believe: A Biblical Exposition of 27 Fundamental Doctrines (Hagerstown, MD: Review and Herald, 1988), 352.

${ }^{2}$ Granger E. Westberg, Good Grief (Philadelphia, PA: Fortress Press, 1971), 49-51.

${ }^{3}$.John W. James and Frank Cherry, The Grief Recovery Handbook: A Step-by-Step Program for Moving Beyond Loss, $1^{\text {st }}$ ed. (New York: Harper \& Row, 1988), 3.

${ }^{4}$ Doug Manning, Don't Take My Grief Away: What to Do When You Lose a Loved One (San Francisco: Harper \& Row, 1984), 60.

${ }^{5}$ Charles A. Corr, Clyde M. Nabe, and Donna M. Corr, Death and Dying, Life and Living, $3^{\text {rd }}$ ed. (Belmont, CA: Wadsworth/Thomson Learning, 2000), 213-217.
} 
The Grieving Process consists of the responses of the mind, body, and spirit to the loss of a loved one, voluntarily or involuntarily. "The experience of Grieving itself may be rich in choice. At the most basic level we have a choice of whether to attend to the distress occasioned by our loss, to feel and explore the grief of our loved one's absence, or to disattend to or suppress our private pain and focus instead on adaptation to a changed external reality."1

Mourning is the time when people voluntarily come together on a small scale, publicly, privately or personally, as a way of seeking closure of a relationship with the deceased and/or to support the family. It represents "the culturally defined acts that are usually performed after a death. For most individuals in our [American] culture, mourning is on a small scale, private, and personal. ... There is a visitation period before the funeral and a short graveside service before the burial. The funeral itself is usually stylized and brief. On the other hand, prominent figures require more outward signs of mourning, such as large military displays or, at least, flags flown at half-mast."

Resolution of Grief is accepting the reality of the loss both cognitively and emotionally by intentionally reorganizing the many facets of one's life to accommodate the absence of the deceased. This is not a return to 'one's old self,' because the death of a loved one changes us and our world profoundly and permanently. Resolution is referred to as a 'process' because the efforts to adjust never really end and require continuing energy, albeit to varying degrees. ${ }^{3}$

\footnotetext{
'Kenneth J. Doka and Joyce Davidson, Living with Grief When Illness Is Prolonged (Bristol, PA Taylor \& Francis), 169.

${ }^{2}$ Sanders, 5 .

${ }^{3}$ J. William Worden, Grief Counseling and Grief Therapy: A Handbook for the Mental Health Practitioner, $3^{\text {rd }}$ ed. (Hove, East Sussex: Brunner-Routledge, 2003), 45-47.
} 
Unresolved Grief is grief that has not been dealt with. It can manifest itself after a single death or as a result of multiple deaths that are not dealt with. In the latter case it is referred to as having a cumulative effect.

$A$ believer is a person who has accepted Jesus Christ as their personal Savior and is a Christian.

A non-believer is a person who has not accepted Jesus Christ as their personal Savior and is not a Christian.

\section{Definition of Biblical Terms Related to Grieving}

Below is a brief discussion of specific terminology that will come up in the course of a Grief Ministry Seminar that warrants attention (see Appendix B).

Purgatory is when a loved one dies. The soul is not really dead but alive in purgatory to undergo purification, so as to receive the holiness necessary to enter the joy of heaven. After purification the righteous soul goes straight to heaven. Those who die in mortal sin immediately after death descend into hell to suffer the punishment of hell, eternal fire. ${ }^{1}$

Reincarnation is when beliefs come in many forms. For the Western and more sophisticated Eastern believers, human beings always inhabit human bodies however, it has also been a widely held belief that the body into which a person migrates can be that of an animal, a plant, or even an inanimate object. ${ }^{2}$

\footnotetext{
${ }^{1}$ Joseph Cardinal Ratzinger, Catechism of the Catholic Church, $2^{\text {nd }}$ ed. (Washington, DC: United States Catholic Conference, 1994), 266-276.

${ }^{2}$ Paul Edwards, Reincarnation: A Critical Examination (Amherst, NY: Prometheus Books, 1996), 12.
} 
Transmigration is a broader term, "usually indicating a passage across the boundaries of all forms of existence (plant, animal, human, demonic, and divine), the passage of one's soul, or vital essence, into the bodies of newly-humans or other life forms."

The Bible teaches that when a person dies, the spirit (breath) returns to God who gave it at creation (Gen 2:7) and the body returns to the earth as it was (Gen 2:6; Eccl 12:7) whether they were righteous or wicked.

The Spirit is the breath of life that Jesus breathed into the nostrils of man and woman and they became living souls (Gen 2:7; Job 27:3).

Mortal means subject to death. Humankind is mortal and will die (2 Cor 4:11; Job 4:17). All souls are subject to death (Rom 5:12). Therefore the concept that humankind is undying or immortal goes against the biblical teachings.

Immortal means not subject to death. Only God is immortal (1 Tim 1:17;6:15, 16).

The soul is a living being, a combination of body (dust) plus breath (spirit) (Gen 2:7). When a person dies he or she is no longer a soul. After death the person returns to the dust (Ps 104:29); knows nothing (Eccl 9:5); possesses no mental power (Ps 146:4);

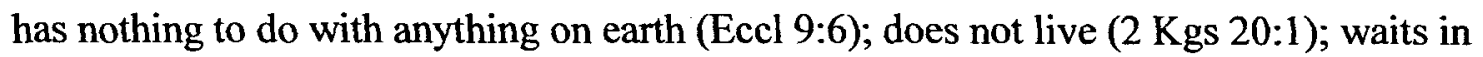
the grave (Job 17:13).

Heaven is where the trinity resides, "Our Father in heaven, hallowed be your name" (Matt 6:9). Jesus proclaimed to Nicodemus that heaven is above "no one has

\footnotetext{
'Farnaz Ma'Sumian, Life After Death: A Study of the Afterlife in World Religions (Rockport, MA: Oneworld Publication, 1995), 112.
} 
ascended into heaven except the one who descended from heaven, the Son of Man" (John

3:13). When Jesus left this earth He ascended into heaven (Acts 1:9-11).

Millennium is a thousand-year period of time between the Second Coming of

Jesus Christ and the destruction of this world by fire (Rev 20:6). This is the belief of the Seventh-day Adventists.

Hell is the fire with which God consumes the wicked after the millennium. They are raised at the end of the thousand years; this is the second resurrection. Then the books will be opened and they are judged (Rev 20:11-13). Death and Hades, and anyone not found written in the Book of Life, will be cast into the lake of fire (Rev 20:10, 14, 15). This is the second death. They shall be as stubble that burn up (Isa 47:14) and become ashes under the sole of the righteous feet (Mal 4:1-3). Sin and sinner will be forever destroyed, annihilated.

New Heaven and New Earth - God will create a new heavens and a new earth immediately after the Millennium (Isa 65:17, Rev 21:5). The new earth will be the eternal home of the righteous (2 Pet 3:13). The tabernacle of God is then with men. It is after the thousand years that all things will be made new and the kingdom of our God and our Lord Jesus Christ will be set up on planet Earth and together we shall live forever and ever $(\operatorname{Rev} 21: 1-22: 5)$.

\section{Additional Information Regarding Biblical Definitions}

Because of death's illusiveness, people turn to religious leaders for wisdom, knowledge, and understanding. Most world religions teach one of three schools of thought - purgatory, reincarnation, or transmigration. Many people find it difficult to 
accept many of their teachings because they create more questions about the love and justice of God.

The distorted concept of death was instituted by Satan in the Garden of Eden when he said, "You shall not surely die" (Gen 3:4; Rev 12:9). This lie became one of the cornerstones of the devil's kingdom. This great deception has brought into the world spiritualism, a belief that supernatural agents receive power and wisdom from the spirits of the dead. ${ }^{1}$ Those who believe that the dead are alive become easy targets for the devil's deceptions. Paranormal manifestations are Satan and his angels impersonating loved ones and others who are now dead (2 Cor 11:13).

The Bible is the only resource that keeps the believer from being deceived by these incredible miracles (Matt 24:24; Rev 16:14). Spirits of the dead do not exist. Therefore, God's people, the elect, will reject all miracle workers and teachers who claim to receive special "light" or work miracles by contacting the spirits of the dead (Acts 17:11; Isa 8:30). God's people will also reject all teachings that claim the dead are alive in any form, anywhere (Lev 20:27).

The faithful died without having received the promise and are waiting in their graves for the second coming of Jesus Christ from heaven (Heb 12:1, 2). This waiting is confirmed by Paul as he gives us the assurance and reassurance of the power of the first resurrection: the dead in Christ will rise first, then we who are alive and remain shall be caught up together to meet the Lord in the air. And thus we shall always be with the Lord (1 Thess 4:13-18).

\footnotetext{
'Seventh-day Adventist Encyclopedia, 1996 ed., s. v. "spiritualism."
} 
The Apostle John in the book of Revelation makes this profound proclamation, "Blessed and holy is he who has part in the first resurrection. Over such the second death has no power, but they shall be priests of God and of Christ, and shall reign with Him a thousand years" in heaven (Rev 20:6).

\section{Literature Review}

Within the last fifty years Elisabeth Kubler-Ross has dominated in the research of death and dying with her five emotional stages of dying - denial, anger, bargaining, depression, and acceptance. Her work was primarily with terminally ill patients. Her objective was, "Simply an account of a new and challenging opportunity to refocus on the patient as a human being, to include him in dialogues, to learn from him the strengths and weakness of our hospital management of the patient."1 Many authors and professionals have taken these stages and translated them into stages that are experienced by the bereaved after the death of a loved one. In their book, The Grief Recovery Handbook, John James and Russell Freedman make this bold statement, "While Dr. Kubler-Ross' contributions brought heightened awareness about the process of dying, her work had been accompanied by some unfortunate collateral damage. Many people, professionals and the general public alike, have attempted to apply her stages to the emotions that arise after a loss." ${ }^{2}$ Although it may be true that these emotions can be a part of the grieving process, they are not absolute or sequential and should not be treated

\footnotetext{
${ }^{1}$ Elisabeth Kubler-Ross, On Death and Dying (New York: Macmillan, 1966), 11.

${ }^{2}$ John W. James and Russell Friedman, The Grief Recovery Handbook (New York: HarperCollins, 1998), 11, 12.
} 
as such. A whole range of emotions manifest themselves after the death of a loved one that will be experienced, expressed, or suppressed in many ways.

It must be acknowledged that some grief specialists disagree with the validity of the differentiation between grief terminologies and claim that certain terms are used interchangeably. Catherine Sanders is a contemporary author who has stated that bereavement, grief, and mourning are used interchangeably. ${ }^{1}$ However, later on in her book she makes a distinction among the terms when she defines mourning when addressing the cultural diversity of the death of a loved one. ${ }^{2}$ Although there may be a thin line in the minds of some, the differentiation allows for a more diverse manner of addressing a death and respecting the sensitivity to the different cultures that express their pain in different ways. Diversity in America cannot be hidden and therefore it must be acknowledged, understood, and respected by everyone when it comes to the death of a loved one. Through the eyes of the contemporary authors Alicia Skinner Cook and Daniel S. Dworkin, bereavement is defined from a more therapeutic perspective because it is a general state of being resulting from having experienced a significant loss; ${ }^{3}$ and, Bryce M. Herkert emphasizes the communicative aspects of bereavement - it takes time to work through the emotional loss. ${ }^{4}$ Grief as defined by Doug Manning is more of an

\footnotetext{
'Sanders, 4.

${ }^{2}$ Ibid., 5.

${ }^{3}$ Cook and Dworkin, 18.

${ }^{4}$ Herkert, 93.
} 
on-going process; ${ }^{1}$ and, John W. James and Frank Cherry clearly state that grief is a natural reaction to loss. ${ }^{2}$

Many grief specialists have identified several levels of the grief experience and their impact on the individual and the world around them - Acute Grief, Anticipatory Grief, Chronic Grief, Cumulative Grief, and Good Grief. The following authors have provided a clear picture of the signs to look for in a griever in each of these areas.

Thomas Attig defines the instant pain of loss as Acute Grief. ${ }^{3}$ Anticipatory Grief and Chronic Grief can be considered as a two-sided coin as expressed by Cook and Dworkin. ${ }^{4}$ Expecting someone to die can lead to obsession after the death.

Our grief relative to the death of a loved one is the price we pay for love. Many times we do not take the time to process these losses as they occur and they accumulate. Cumulative Grief, sometimes referred to as Unresolved Grief, according to James North can become torturous. ${ }^{5}$

Charles Corr, Clyde Nabe, and Donna Corr have published three volumes on death and dying with each edition providing a new and refreshing perspective on this vital topic. In their third edition, grieving is not something to be afraid of but valued as a part of a loss. ${ }^{6}$ This is why Doka and Davidson encourage individuals to intentionally enter the Grieving Process that involves embracing the emotional pain of the loss and

\footnotetext{
${ }^{1}$ Manning, 60.

${ }^{2}$ James and Cherry, 3 .

${ }^{3}$ Attig, 47 .

${ }^{4}$ Cook and Dworkin, 18.

${ }^{5}$ North, Grief and Loss.

${ }^{6}$ Corr, Nabe, and Corr, 213-217.
} 
accepting the realities surrounding the new life without the loved one. 'When we enter into the grieving process we are then able to move to resolution. This requires continuous energy, albeit to varying degrees. The goal is to view grief from Granger E. Westberg's perspective, 'good grief.' "Grief grounded in the basic philosophy that by establishing a relationship with God grievers can face any earthly loss with the knowledge that they still have not lost everything. They still have God on whom to rely. It makes an amazing difference in the quality of the grief experience."2

In addressing the biblical approach to grief ministry in chapter 2 the grief of Jacob is shared by several authors who wrote from their perspectives and understanding on the various Scriptures. Elisabeth Kubler-Ross makes a contribution regarding the importance of communication that pulls Jacob's guilt into perspective, "The dying person can be of great help to his relatives in helping them meet his death. . . Guilt is perhaps the most painful companion of death."3

Ellen G. White in Patriarchs and Prophets clarifies many of Joseph's concerns about the eleven sons of Jacob in their visits to Egypt to purchase food during the famine. Her insightfulness provides a clear perspective of the emotional trauma suffered by this biblical family that helps build the foundation for understanding family grief and forgiveness. ${ }^{4}$

White provides astute insights on Jesus' grief in the Desire of Ages relative to the sorrow of the friends of Lazarus, "He was moved by human sorrow. . . . The weight of

\footnotetext{
${ }^{1}$ Doka and Davidson, 168.

${ }^{2}$ Westberg, 49-51.

${ }^{3}$ Kubler-Ross, 142.

${ }^{4}$ Ellen G. White, Patriarchs and Prophets (Mountain View, CA: Pacific Press, 1958), 230.
} 
the grief of ages was upon Him."1 Delbert Burkett states that "the miracle confirms before witnesses that the Father sent Jesus. ${ }^{2}$ It is Sandra Schneider who compares death in the Old and New Testaments by referring to it as resting in Sheol awaiting the general resurrection and affirms that death is temporary and will be overcome. ${ }^{3}$ Frederick Streets's contribution is that the hope in Jesus persists after the death of those whom we love and care about. This is refreshing and positive from a Christian perspective. ${ }^{4}$

As a biblical role model of grief, Abraham spent one hundred years in the Promised Land. His sojourn will provide for us wisdom and understanding relative to God's involvement in this chosen community. Paul Bork escorts the reader into this new relationship created by God with a man who becomes obedient to Him with all his pain and sorrow. ${ }^{5}$ Almost immediately Abram is thrown into trials and tribulations that challenge their tribal existence in this foreign land. Because of a severe famine the clan is forced to go down into Egypt. The SDA Bible Commentary informs us of Pharaoh's fancy for fairer complexion foreign women for the royal harem. We are reminded that Abram perpetuated a lying scheme which, had not God intervened, would have caused Sarai and Pharaoh to engage in adultery. ${ }^{6}$

\footnotetext{
'Ellen G. White, The Desire of Ages (Mountain View, CA: Pacific Press, 1940), 308-309.

${ }^{2}$ Delbert Burkett, “Two Accounts of Lazarus' Resurrection in John 11," Novum Testamentum 36 (July 1994): 217.

${ }^{3}$ Sandra M. Schneider, "Death in the Community of Eternal Life History, Theology, and Spirituality in John 11," Interpretation 41, no: 1 (Fall 1987): 49.

${ }^{4}$ Frederick J. Streets, "Grief and Glory," Christian Century, March 1993, 263.

${ }^{5}$ Paul F. Bork, Out of the City, Across the Sands (Washington, DC: Review and Herald, 1982), 81-82; Ziv Adar, The Book of Genesis: An Introduction to the Biblical World (Jerusalem: Magnes Press, 1990), 50.

6 "Genesis to Deuteronomy," SDA Bible Commentary, ed. F. D. Nichols (Washington, DC: Review and Herald Pub. Assn., 1978) 1:298.
} 
After leaving Egypt his nephew, Lot, separated from him because of the contention between their herdsmen. Henry Wansbrough speaks about Abram's extraordinary generosity to Lot although he is the head of the clan. ${ }^{\prime}$ As painful as this separation may have been, it was compounded when Lot and his fellow countrymen were taken captive and Abraham had to rescue them. William Deane addresses Abram's emotional trauma and military prowess with these words, "With large booty and the rescued Abram returned in peace to the Valley of the Jordan."

Abram suffered the personal grief relative to childlessness during these early years in Canaan. In his suggestion of a human solution for God, authors Keith Essex and W. J. Dumbrell reveal a shift in their communication to a covenant relationship that is sealed by sacrifices and a promise of a son from his own bowels. ${ }^{3}$

Shortly after establishing this covenant with God, Abram succumbs to a marriage to Hagar, Sarai's Egyptian slave, who bears his son, Ishmael. Angel Gonzalez sees this as a solution of Sarai's denial of the normal purpose of her existence. ${ }^{4}$

Regarding Gen 18 and 19, Patrick Reardon focuses in on the prophetic dialogue between God, Abraham and Sarah about their future parenthood that caused laughter, denial, and a firm confirmation promise from God before His departure. ${ }^{5}$ T. Desmond Alexander suggests that Abraham prolonged his discussion with God because of his

\footnotetext{
${ }^{1}$ Henry Wansbrough, Genesis, Doubleday Bible Commentary (New York: Doubleday, 1998), 27.

${ }^{2}$ William J. Dean, Men of the Bible: Abraham, His Life and Times (Chicago: Fleming H. Revell, 1942), 1:68, 69 .

${ }^{3}$ W. J. Dumbrell, "The Covenant with Abraham," The Reformed Theological Review 41 (MayAugust 1982): 42 .

${ }^{4}$ Angel Gonzalez, Abraham: Father of Believers (New York, NY: Herder and Herder, 1967), 66.

${ }^{5}$ Patrick T. Reardon, “Sarah Laughed," U. S. Catholic 65, no. 1 (January 2000): 43-45.
} 
concern for Lot's deliverance on the grounds of righteousness. ${ }^{\prime}$ From an end-time perspective Edward William Fudge reminds us that the concept of the fiery lake of burning sulfur is the last description in the Bible of final punishment. ${ }^{2}$

It is after this that Sarah conceives and bears Isaac according to God's promise. Norman Cohen give their perspective on the dual heirship of Ishmael and Isaac by offering suggestions as to why Sarah requests that Hagar and Ishmael be cast out. We also note Abraham's prayer that evoked God's approval and Abraham's obedience. ${ }^{3}$

Duane Garrett felt that nothing could be more incongruous than God asking Abraham to sacrifice his 'promised' son. ${ }^{4}$ It took them three days to reach Mount Moriah and Abraham suffered alone the whole time. Jacques Doukhan makes this statement, "Justified or not, suffering is always suffering, and explaining it at a human level does not solve anything."5

Carol Ochs sees Isaac's chronic grief of three years as a wake-up call. Abraham sends Eleazer back to his homeland, Ur of the Chaldees, on a mission to get Isaac a wife from among his kinsmen. Rebekah agrees to relocate to Canaan along with two handmaidens to become Isaac's wife and she was able to comfort him. ${ }^{6}$

' T. Desmond Alexander, "Lot's Hospitality: A Clue to His Righteousness," Journal of Biblical Literature 104, no. 2 (1985): 290.

${ }^{2}$ Edward William Fudge, The Fire That Consumes: The Biblical Case of Conditional Immortality (Carlisle, UK: Paternoster Press, 1994), 191.

${ }^{3}$ Norman J. Cohen, Self, Struggle \& Change: Family Conflict Stories in Genesis and Their Healing Insights for Our lives (Woodstock, VT: Jewish Lights Publishing, 1995), 71-73.

${ }^{4}$ Duane Garrett, Rethinking Genesis: The Source and Authorship of the First Book of the Pentateuch (Grand Rapids, MI: Baker Book House, 1991), 167.

5 Jacques Doukhan, "The Problem of Suffering." Shabbat Shalom, December 1994, 13.

${ }^{6}$ Carol Ochs, Song of the Self: Biblical Spirituality and Human Holiness (Pittsburgh, PA: Trinity Press International, 1994), 66. 
Thirty-seven years after Sarah's death, Abraham dies. With regard to Abraham, Henry Gaubert makes this statement, "Abraham's earthly life was over. The history of the Chosen People now began."

Two sources enlighten us about the legacy of Jacob's final hours of dying and his death. The journey from Egypt to Canaan for burial was made possible by the process of mummification as presented by Bob Brier and Hoyt Hobbs. ${ }^{2}$ The Seventh-day Adventist Bible Commentary contributed a lot to the background relative to the relationship Jacob had with his twelve sons, his anticipatory death, the dying process, and the fulfillment of his last will and testament. ${ }^{3}$

In the context of the Seventh-day Adventist culture and grief, Ellen G. White talks openly about her pain, suffering, and grief over the death of her sons and husband (this will be discussed in chapter 3$){ }^{4}$ Her grandson, Author L. White, adds material relative to the White family's losses to broaden the understanding of the grief and pain experienced during the dying and death of their loved ones. ${ }^{5}$

The book Seventh-day Adventists Believe: A Biblical Exposition of 27

Fundamental Doctrines of the Seventh-day Adventists contains a thorough knowledge of

\footnotetext{
${ }^{1}$ Henri Gaubert, Abraham, Loved by God (New York: KS Giniger Company; 1968), 184.

${ }^{2}$ Bob Brier and Hoyt Hobbs, Daily Life of the Ancient Egyptians (Westport, CT: Greenwood Press, 1999), 47-53.

3 "Genesis to Deuteronomy," SDA Bible Commentary, 1:474-486.

${ }^{4}$ Ellen G. White, Selected Messages, Book 2 (Washington, DC: Review and Herald , 1958), 258.

${ }^{5}$ Arthur L. White, Ellen G. White: Progressive Years 1863-1875 (Hagerstown, MD: Review and Herald, 1986), 70-72.
} 
the Doctrine of Last Things. This book provides the pre-requisite for the training of facilitators. ${ }^{1}$

For an understanding of the role the human mind plays in the great controversy between Satan and Christ, Frank Phillips talks about the need to understand how the human mind works in his book, His Robe or Mine? It is his insight that lays the groundwork for the six intensive two-hour sessions.

The human mind has been compared to a computer in which the memory bank is being programmed every waking moment by one of two sources: Christ or Satan. Like the computer, the mind's function depends upon the information it receives. Having analyzed the information, the mind then determines its decision and subsequent course of action. $^{2}$

Learning how to manage stress is a top priority in society today. In order to assess the stress level of the participants, T. H. Holmes and R. H. Rahe have developed a social requirement rating scale known as the Self-Assessment on Life Events Scale. This allows each individual to know instantly where their stress level is relative to their life events. $^{3}$ This self-assessment is followed by J. Jeffrey Means's reminder of the times in which we live and how this affects our behavior and the understanding of our environment. $^{4}$

\footnotetext{
'Ministerial Association, 311-383.

${ }^{2}$ Frank B. Phillips, His Robe or Mine? (Berrien Springs, MI: Lithotech, 2003), 12.

${ }^{3}$ T. H. Holmes and R. H. Rahe, "The Social Requirement Rating Scale," Journal of Psychological Research 2 (1967): 213.

4 J. Jeffrey Means, "Mighty Prophet, Wounded Healer," The Journal of Pastoral Care \& Counseling, 56, no. 1 (2002): 46.
} 
As we move into the area of grief, Granger Westberg in contrast with Elisabeth Kubler-Ross's Five Stages of Death introduces Ten Emotional Stages of Grief (shock, emotion, depressed and very lonely, physical symptoms of distress, panicky, sense of guilt about the loss, anger and resentment, resist returning, hope and affirm reality) as the experience of survivors of the deceased. ${ }^{1}$ Larry Yeagley presents several simple exercises on how to be good to yourself that an individual may add to their lives that will help them move toward health and healing in a timely manner. ${ }^{2}$ One of the most practical exercises that is known to enhance the spiritual aspect of life, Breath Prayer, is presented by Ron Del Bene, Mary Montgomery, and Herb Montgomery. ${ }^{3}$ Loneliness is considered as one of the most destructive circumstances that death leaves behind and there seems to be no way to escape this condition. However, Mark Finley provides simple ways for the griever to handle loneliness. ${ }^{4}$

\section{The Expectations from This Dissertation}

My expectations from this dissertation are as follows:

To transpose this three-day Grief Ministry Seminar format into other convenient formats to be held throughout the North American Division and the denomination To make appropriate cultural modifications in this seminar that can be used worldwide

\footnotetext{
${ }^{1}$ Westberg, 21-63.

${ }^{2}$ Larry Yeagley, Grief Recovery (Charlotte, MI: The author, 1998), 61-63.

${ }^{3}$ Ron DelBene, Mary Montgomery, and Herb Montgomery, When I'm Alone: Thoughts and Prayer That Comfort (Nashville, TN: The Upper Room, 1988), 7-9.

${ }^{4}$ Mark A. Finley, Lonely No Longer (Fallbrook, CA: Hart Research Center, 1993), 80.
} 
To incorporate cultural and doctrinal issues of non-Seventh-day Adventist Christians in an effort to heighten sensitivity

To expand local grief recovery programs to include specialized programs for youth, teenagers, and the elderly

To increase denominational support for grief ministry beginning at the local congregation and to expand it to the local conferences, North American Division, and General Conference

To increase General Conference support for grief ministry to become an international ministry for the world church

To become a consultant ministry for Adventist independent ministries, such as ADRA, Global Missions, ASI, Frontier Missions, etc.

To enhance my spiritual growth and development in the hope and assurance in the power of the resurrection by our Lord and Savior Jesus Christ at His second coming for all believers. 


\section{CHAPTER II}

\section{A BIBLICAL APPROACH TO GRIEF MINISTRY}

The Bible is full of historical grief narratives with sequences of events relative to how biblical characters reacted and responded to the death of loved ones. Even the crises in their families, communities, and the nations around them are exposed to us. These stories are written for our benefit. The objective is for us to relate to these stories to gain an understanding of the relationship between God and humankind. In this chapter we will observe Grief Ministry through the lenses of both the Old and New Testaments.

The Old Testament gives more stories on grief and death whereas the New Testament gives more doctrine. In the Old Testament we will look at the father and son relationship of Jacob and Joseph, who grieved twenty-two years (Gen 37:2;41:46; 45:6) ${ }^{1}$ for each other; and we will analyze portions of Abraham's life that will serve as a biblical role model for grief. In the New Testament we will observe the friendship between Jesus and the family in Bethany-Lazarus, Mary, and Martha.

For the earnest seeker, each of these models may become a source of understanding as we carefully watch these characters weave in and out of different stages of grief and then move to grief resolutions through the power of God. We will also get a glimpse of God's eternal ministry to the bereaved through His promises of a future when there will be no more grief. All of this should lead us to a better understanding of how to

\footnotetext{
${ }^{1}$ The New Revised Standard Version (NRSV) is quoted in all biblical references except where otherwise noted.
} 
handle our grief today and encourage us to search the Scriptures for a deeper insight into grief ministry.

\section{An Old Testament Approach to Grief Jacob's Grief for Joseph (Genesis)}

Joseph was the firstborn son of Jacob and Rachel (30: 22-24). Rachel, the younger daughter of Laban and sister to Leah (29:16), was Jacob's first love (29:18). He worked fourteen years for her (29:20-30). ${ }^{1}$

Jacob loved Joseph more than any of his older children because he was the son of Jacob's old age. He demonstrated this affection by making Joseph a special robe. ${ }^{2}$ When his brothers saw it, they hated Joseph and could not speak peaceably to him. As a young shepherd helping his brothers, Joseph brought a bad report of them to Jacob (37:1-4).

Joseph was also a dreamer, which caused him to experience his brothers' hatred even more when he shared his dreams of supremacy over them and extended it to the entire family. ${ }^{3}$ They said, "Are you indeed to reign over us? Are you indeed to have dominion over us?" (37:8). Even Jacob rebuked him: "What kind of dream is this that

\footnotetext{
1 "Many as were the days that must pass before Rachel should become his bride; they were rendered happy by his love for her. ... Jacob found it necessary to remind him [Laban] of the expiration of the seven years. A great marriage feast was prepared, according to the usual custom. Laban's deception of Jacob was possible because of the custom of veiling the bride and bringing her to the bridegroom 'in the evening.' Although girls usually had little choice in the selection of their husbands, Leah's consent was necessary to the success of this base proposal. She must herself have loved Jacob, to approve and cooperate in the plan to wrong both her sister and her future husband by marrying one who neither sought nor loved her. Laban's duplicity resulted in a lifelong rivalry between the sisters." "Genesis to Deuteronomy," SDA Bible Commentary, 1:386-387.

2Jacob's preferential treatment of Joseph reached a climax in the special coat, or tunic, he made for him. The meaning of the word passim, "of many colors," is uncertain. The Scripture makes reference to this coat as a "Long Coat with sleeves" (NRSV), "Tunic of Many Colors" (NKJV), and "Coat of Many Colors" (KJV), which implies Jacob's intention of making Rachel's oldest son his heir. Ibid., 428-429.

${ }^{3}$ They hated him not only because of the dream, but also for his boldness in telling them about it (vs. 8). Though it is not stated that Joseph's dreams were of God (20:3-7; 28:12-15), the subsequent history of his life makes it virtually certain that this was so, and that they were not the reflection of any personal ambition on his part. Ibid., 429.
} 
you have had? Shall we indeed come, I and your mother and your brothers, and bow to the ground before you?" $(37: 10)$. His brothers were jealous of him, but his father kept the matter in his mind $(37: 8,11)$. This jealousy manifested itself when his brothers sold him to itinerant travelers on their way to Egypt.

Jacob's grief began for Joseph when his ten sons came to him with Joseph's robe stained with blood. "This we have found: see now whether it is your son's robe or not."' Recognizing the robe, Jacob said, "It is my son's robe! A wild animal had devoured him; Joseph is without doubt torn to pieces" (37:31-33).

Jacob's initial reaction may have been partially based on a feeling of guilt. ${ }^{2} \mathrm{~A}$ few days earlier, Jacob had sent Joseph from Hebron to see if it was well with his brothers and the flock and to bring word back (37:12-14).

Jacob's physical response to the apparent shocking news was to tear his garments, put sackcloth on his loins, and mourn for his son many days. ${ }^{3}$ He rejected the grief ministry of his daughters who sought to comfort him. He refused to be comforted and said, "No, I shall go down to Sheol to my son, mourning. 4 Thus (Jacob) his father

\footnotetext{
I "Jacob cried out for his son with deep intensity. With traditional signs of mourning, Jacob laments for many days; his children (daughters, i.e., Dinah and his daughters-in-law) are unable to comfort him. He will lament until the days of his death. ... Perhaps Jacob thought his mourning would continue even beyond death. The brothers sought to displace Joseph in their father's affections, but, ironically Joseph will retain a preeminent place in his father's love even in death." "General and Old Testament Articles Genesis, Exodus, Leviticus." The New Interpreter's Bible: A Commentary in Twelve Volumes, ed. Nolan B. Harmon (Nashville, TN: Abingdon Press, 1996), 1:600.

2 "Guilt is perhaps the most painful companion of death." Kubler-Ross, 142.

3 "Sackcloth is a coarse, black cloth made from goat's hair that was worn together with burnt ashes for personal and national disaster, as a sign of repentance and at times of prayer for deliverance ... a sign of mourning for the dead by Jacob for Joseph (Gen 37:34)," Zondervan Dictionary of Bible Themes (1999), s.v. "Sackcloth."

4 "Sheol is the most common word used in the Hebrew Bible to refer to the abode of the dead. It is the place where all the dead, both righteous and wicked, eventually reside. It is typically depicted as a place to which one 'goes down.' The lowest part of the under world." Anchor Bible Dictionary (1992), s.v. "Sheol."
} 
bewailed him" (37:35). What ordinarily should have been acute grief immediately became chronic grief because of his prophetic statement about himself.

Meanwhile in Egypt Joseph is also dealing with his acute grief. After thirteen years of being a slave and a prisoner, God provides grief ministry for Joseph. When he rises to power and becomes the second in command of Egypt, Pharaoh gives him a wife, Asenath, who bears him two sons. Joseph called the name of the firstborn Menasseh meaning, "For God has made me forget all my hardship and all my father's house." The second son he named Ephraim, "For God has made me fruitful in the land of my misfortunes" (Gen 41:37-57). At this time we could consider this as Good Grief.

Two years into the prophetic seven-year famine, the ten brothers traveled to Egypt to buy food. They are confronted by the Governor of Egypt who questions them about their father, Jacob; and their younger brother, Benjamin (42:6-25). They did not recognize him as Joseph through several trips to Egypt. After the governor of Egypt had imprisoned Simeon and they returned home without him, Jacob's reaction indicated chronic grief. His grief was intensified by the testing the Governor did with his sons. He still grieved the loss of Joseph and now anticipated the loss of his son Simeon. "I am the one you have bereaved of children: Joseph is no more, and Simeon is no more, and now you want to take Benjamin. All this has happened to me!" (42:36). Reuben, although this is a misconception of grief ministry, in an attempt to console his father says, "You may kill my two sons if I do not bring him [Benjamin] back to you. Put him in my hands and I will bring him back to you" (42:37). But Jacob said, "My son shall not go down with you, for his brother is dead, and he alone is left. If harm should come to him on the 
journey that you are to make, you would bring down my gray hairs with sorrow to Sheol" (Gen 42:38).

When they had eaten up the grain from Egypt and Jacob asked them to go again, they reminded him of the Governor's request, "You shall not see my face, unless your brother [Benjamin] is with you" (43:3). After much discussion of his very limited choices, Jacob surrendered with this statement:

If it must be so, then do this: take some of the choicest fruits of the land . . a little balm, a little honey, gum, raisin, pistachio nuts, and almond . . take your brother also, and be on your way again to the man; may God Almighty grant you mercy before the man, so that he may send back your brother [Simeon] and Benjamin. As for me, if I am bereaved of my children, I am bereaved. (43:11-14)

Upon their arrival in Egypt the brothers' grief was relieved when Simeon was returned to them. The governor imposed several tests on them to see if they had had a change of heart.' It could be said that Judah's plea for Benjamin's release gave Joseph permission to express his grief and enter into the grieving process ${ }^{2}$ (44:18-34). After this series of events Joseph revealed himself to his brothers by weeping upon them, embracing them and expressing his affection (45:1-15).

The brothers returned to Jacob in the Land of Canaan with Simeon, Benjamin, and wagons with provisions for the family to journey to Goshen. Jacob, at first, was not

\footnotetext{
'At the feast, "When all were seated the brothers were surprised to see that they were arranged in exact order, according to their ages. Joseph set messes unto them from before him; but Benjamin's was five times as much as any of theirs. Before their departure he ordered that his own cup of silver should be concealed in the sack of the youngest. . . . Overtaken by the governor's steward ... searched . . . returned to the city ... Joseph was satisfied. He had seen in his brothers the fruit of true repentance." E. G. White, Patriarchs and Prophets, 228-230.

2 "In his deep distress Judah now drew near to the ruler and exclaimed, 'O my lord, let the servant, I pray thee, speak a word in my lord's ear, and let not thine anger burn against thy servant: for thou art even as Pharaoh.' In words of touching eloquence he described his father's grief at the loss of Joseph and his reluctance to let Benjamin come with them to Egypt, as he was the only son left of his mother, Rachel, whom Jacob dearly loved. Seeing that his life is bound up in the lad's life; it shall come to pass, when he seeth that the lad is not with us, that he will die: and thy servants shall bring down the gray hairs of thy servant our father with sorrow to the grave." Ibid., 230.
} 
impressed. But the good news-“Joseph is still alive! He is even ruler over the land of Egypt-stunned Jacob so much that he could not believe it" (45:26). His excitement came as the brothers recited the words of Joseph and when Jacob saw the wagons that Joseph had sent to carry him back, the spirit of their father revived. In search for grief resolution Israel said, "Enough! My son Joseph is still alive. I must go and see him before I die" (45:28).

The Bible speaks about the joy and anticipation Jacob felt as they neared Egypt; and of Joseph's preparation as he waited patiently for the arrival of his family. The Bible says, "So Joseph made ready his chariot and went up to Goshen to meet his father Israel; and he presented himself to him, and fell on his neck and wept on his neck a good while. And Israel said to Joseph, 'Now let me die, since I have seen your face, because you are still alive"" $(46: 29,30)$. This was not only a family reunion; we can also consider this as an Old Testament example of grief ministry.

Grief ministry in the Old Testament seems to have been very intense within Jacob's family. There were times when family members tried to comfort the griever only to be rejected and denied the opportunity to serve. Many times acute grief would become chronic grief and it appeared that there was also a misconception of the grieving process. However, God provided grief resolution that brought about reunion in this family and allowed them to move toward healing. We will visit this patriarch again in chapter 3 where there is a model in dying and death that we must examine because of its effect on our lives today and our future.

Turning to the New Testament as the doctrinal source on grief ministry we find an abundance of wisdom from Matthew to Revelation; however it is important for us to 
carefully examine how Jesus related to grief and the messages He shared and demonstrated before us.

\section{A New Testament Approach to Grief Death and Resurrection of Lazarus}

Lazarus is referred to as a disciple of Jesus who lived in Bethany with his sisters Mary and Martha. ${ }^{1}$ Ellen G. White penned this statement to provide a clear picture of the kind of home environment Jesus enjoyed at Bethany:

Christ had no home of his own. He was dependent on the hospitality of his friends and disciples. The home of the family at Bethany was one of the Savior's homes. Here he could find rest and repose. Often when weary, thirsty for human fellowship, he had been glad to escape to this quiet home, away from the suspicion and jealousy of the angry Pharisees. Here he found a sincere welcome and pure, holy friendship. Here he could speak with simplicity and perfect freedom, knowing that his words would be understood and treasured. He was able here to accomplish the work for which he came to earth. ${ }^{2}$

Lazarus became severely ill and the sisters, in anticipation of his death and their grief, turned to Jesus. This was a desperate cry for help. They sent this urgent message to Jesus, "Lord, he whom you love is ill" (John 11:3). Their expectations were met with a delay. He responded verbally to his disciples, "This illness does not lead to death; rather it is for God's glory, so that the Son of God may be glorified through it" (11:4). He stayed two days longer. ${ }^{3}$ Then He said to His disciples, "Let us go to Judea again. . . .Our friend Lazarus has fallen asleep, but I am going there to awaken him. . . . Lazarus is dead.

1 "Jesus had often found the rest that his weary human nature required at the house of Lazarus, in Bethany. His first visit there was when he and his disciples were weary from a toilsome journey. . . They tarried as guests at the quiet home of Lazarus, and were ministered unto by his sisters, Martha and Mary." Ellen G. White, The Spirit of Prophecy (Battle Creek, MI: Steam Press, 1877), 358.

${ }^{2}$ Ellen G. White, "The Resurrection of Lazarus," Youth Instructor, March 30, 1899, 2.

3 "Here the motivation for Jesus' delay is expressed without interruption: Jesus delays two days until Lazarus dies in order that God and His Son might receive glory through raising him." Burkett, 217. 
For your sake I am glad I was not there, so that you may believe. But let us go to him"l $(11: 4-15)$

When Jesus arrived Lazarus had already been in the tomb four days, and many of the Jews had come to Martha and Mary to console them. When the sisters heard that Jesus was coming, they separately went out to meet him. Martha was told first and so she went to meet him. Martha's dialogue with Jesus revealed her acute grief and the pain she was enduring relative to the loss of her brother. It even provides insight into her theological understanding of the future - the resurrection (11:21-27).

Martha: "Lord, if you had been here, my brother would not have died. But even now I know that God will give you whatever you ask of him."

Jesus: "Your brother will rise again." (As strange as it may seem, Jesus allowed his friend to die to give us tangible evidence of the resurrection.)

Martha: "I know that he will rise again in the resurrection on the last day."

Jesus: "I am the resurrection and the life. Those who believe in me even though they die, will live, and everyone who lives and believes in me will never die. Do you believe this?"

Martha: "Yes, Lord, I believe that you are the Messiah, the Son of God, the one coming into the world."

Then Martha went and told Mary privately, "The Teacher is here and is calling for you,"

Mary got up quickly and went to Him" (11:28-44).

1 "In the conversation with the disciples in verses 5-16 the question which has been answered negatively . . . is raised positively. In the early church death was often referred to as 'falling asleep.' 'There is a fundamental difference between the Old Testament and the New Testament use of the term. In the former the dead was understood to be resting in Sheol awaiting the general resurrection. In the New Testament, the metaphor of sleep is not an attempt to describe the state of the deceased in the afterlife but to affirm that death is temporary because, finally, it will be overcome by the resurrection of Jesus." Schneider, 49.

2 "Martha exhibits weak faith. When Jesus stated that her brother will rise, she hesitated to think of an immediate resurrection, agreeing only that he will rise on the last day (vv23-24). The hesitation ill fits with her confident assertion just two verses earlier. . . Only after Jesus assures her that his presence means resurrection now is she led to a confession of what she believes about Jesus-still, however, expressing no explicit hope for her brother." Burkett, 219. 
Mary: (Expressed the same sentiments as her sister earlier with tears and deep sorrow.) "Lord, if you had been here, my brother would not have died."

Jesus: $\quad$ (When Jesus saw her weeping, and the Jews who came with her also weeping, he was greatly disturbed in spirit and deeply moved.) "Where have you laid him?"

Mary/Martha: "Lord, come and see."

Jesus: $\quad$ Jesus began to weep.' (Jesus began to weep not out of grief for Lazarus but in empathy with the other grievers because he was going to resurrect Lazarus. This shows us Jesus' endorsement of public weeping. Paul says, "Rejoice with those who rejoice, weep with those who weep" [Rom 12:15]. Further, Jesus considered death as a sleep from which he would call Lazarus from, not as an unopenable prison.)

The Jews: "See how he loved him!" (People thought he was grieving over Lazarus, but obviously they misunderstood.)

Some Jews: "Could not he who opened the eyes of the blind man have kept this man from dying?"2

Jesus: $\quad$ (Greatly disturbed.) "Take away the stone."

Martha: "Lord, already there is a stench because he has been dead four days."

Jesus: "Did I not tell you that if you believe, you would see the glory of God?" (So they took away the stone. And Jesus looked upward and said ...) 'Father, I thank you for having heard me. I knew that you always hear me, but I have said this for the sake of the crowd standing here, so that they may believe that you sent me."' (When he had said this, he cried with a loud voice ....) "Lazarus, come out!"

Lazarus: (The dead man came out, his hands and feet bound with strips of cloth, and his face wrapped in a cloth.)

1 "It was not only for the scene before Him that Christ wept. The weight of the grief of ages was upon Him ... Looking down the years to come, He saw the suffering and sorrow, tears and death that were to be the lot of men. His heart was pierced with the pain of the human family of all ages and in all lands. The woes of the sinful race were heavy upon His soul, and the fountain of His tears was broken up as He longed to relieve all their distress." E. G. White, Desire of Ages, 535.

2 "The fact is that many Jews have come to comfort the sisters. ... The miracle confirms before witnesses that the Father sent Jesus." Burkett, 255.

3 "Jesus embodies hope in the presence of death, and a hope that persists after the death of those who we love and care about. .. . The ultimate gift of our vulnerability is believing in the power of a God over death." Streets, 263. 
Jesus: "Unbind him, and let him go."

The following statements typify the human reactions to the miracle performed by Jesus and the response that follows when the reality of the event settles upon the human mind.

The beholders are at first speechless with amazement. Then there follows an inexpressible scene of rejoicing and thanksgiving. The sisters receive their brother back to life as the gift of God, and with joyful tears they brokenly express their thanks to the Saviour. But while brother, sisters, and friends are rejoicing in this reunion, Jesus withdraws from the scene. When they look for the Life-giver, He is not to be found. ${ }^{1}$

Many people are surprised when they read this portion of the story because they wait in anticipation for a report from Lazarus about what happened while he was dead. The truth of the matter is that there is nothing to tell; Lazarus was asleep for four days. Solomon reminds us that the dead know nothing (Eccl 9:5).

This resurrection and Jesus' own resurrection are only a preview of what God has planned for His children. The plan of salvation is fulfilled and Jesus is just waiting for the command to return to Earth to receive us unto Himself and to present us in heaven to the Father (John 14:1-4). The only difference between His earthly grief ministry and His heavenly grief ministry is the Second Coming when He will come in all His glory and the glory of the Father. Resurrection morning will be the beginning of an eternity when there will be no more dying, death, grief, or pain because God will put an end to suffering. He will wipe away all tears from our eyes. This hope is a part of the plan of salvation laid before the foundation of the earth.

\footnotetext{
' E. G. White, Desire of Ages, 536.
} 


\section{God's Eternal Approach to Grief Ministry}

God's plan of salvation was a part of the creation of humankind. This plan consists of four gifts - reconciliation, resurrection, eternal life, and immortality - that only God could give as an expression of His love for His disobedient children.

\section{The First Gift-Reconciliation}

Reconciliation indicates that we were once enemies of God because we are sinners. Many times we blame Adam and Eve for this curse. It is true that by Adam's sin death came upon the entire human race; but God, by Jesus' righteousness, has made eternal life available to all who will accept it.

For if while we were enemies, we were reconciled to God through the death of his Son, much more surely, having been reconciled, will we be saved by his life. But more than that, we even boast in God through our Lord Jesus Christ through whom we have now received reconciliation. (Rom 5:10-21)

"Without the shedding of blood there was no forgiveness for our sin.

Consequently when Christ came to the world, he said, 'Sacrifices and offerings you have not desired, but a body you have prepared for me. . . See, God, I have come to do your will, O God"" (Heb 9:22-10:5, 7). It is with these words and His actions that we have been sanctified through the offering of the body of Jesus Christ once for all. And it is from this vantage point that we have been called to the Ministry of Reconciliation.

All of this is from God, who reconciled us to Himself through Christ, and has given us the ministry of reconciliation; that is in Christ. God was reconciling the world to Himself, not counting their trespasses against them and entrusting the message of reconciliation to us. So we are ambassadors for Christ, since God is making His appeal through us; we entreat you on behalf of Christ, be reconciled to God. For our sake He made Him sin, so that in Him we might become the righteousness of God. (2 Cor 5:18-21) 


\section{The Second Gift-the Resurrection}

Under a code of silence as Peter, James, and John descended the Mount of Transfiguration with Jesus, he said, "Tell no one about what they [you] have seen, until after the Son of Man has risen from the dead. So they kept the matter to themselves, questioning what this rising from the dead could mean" (Mark 9:6-8).

After the resurrection and ascension Peter standing with the eleven apostles addressed the crowd in Jerusalem with these words:

Fellow Israelites, I may say to you confidently of our ancestor David that he both died and was buried, and his tomb is with us to this day.... Foreseeing this, David spoke of the resurrection of the Messiah, saying, "He was not abandoned in Hades, nor did his flesh experience corruption." This Jesus God raised up, and of that all of us are witnesses. (Acts $2: 32 ; 3: 15$ )

Peter goes on to say to everyone who has accepted the called to holy living:

You know you were ransomed from the futile ways inherited from your ancestors, not with perishable things like sliver or gold, but with the precious blood of Christ, like that of a lamb without defects or blemish. He was destined before the foundation of the world, but was revealed at the end of the ages for your sake. Through him you have come to trust in God, who raised him from the dead and gave him glory, so that your faith and hope are set on God. (1 Pet 1:18-21)

The resurrection of Jesus brought hope to humankind that death is not the end of the story. Death is only a state of temporary lifeless unconsciousness while the person awaits the resurrection. The power of the resurrection was clearly demonstrated by Jesus in the resurrection of Lazarus during His sojourn on earth (John 11) and His own resurrection (Mark 16). In His prayer He remembered those of us who would have to walk by faith and believe the words of those who bore witness of His presence two thousand years ago (John 17:20-23). 


\section{The Third Gift-Eternal Life}

The Apostle John speaks boldly about this gift and testifies that this gift is available to the believer right now.

And this is the testimony: that God has given us eternal life, and this life is in His Son. He who has the Son has life; he who does not have the Son of God does not have life. These things I have written to you who believe in the name of the Son of God, that you may know that you have eternal life, and that you may continue to believe in the name of the Son of God. (1 John 5:11-13)

In the original language the tense in each instance of the verb "to have" is present tense, which means eternal life is a present reality. Eternal life is given as an earnest or a pledge or a promise for the fourth gift which is given at the first resurrection. ${ }^{1}$

The straightforwardness of this reality is a call for a personal relationship with Jesus. When Jesus was speaking with Nicodemus about the new birth and His mission, He acknowledged that He (the Son of Man) had come down from heaven and whoever believes in Him should not perish but have eternal life. Jesus shared that the Father loved the world so much that He sent Him into the world to save the world and not condemn those who believe in His name (John 3:1-21).

\section{The Fourth Gift-Immortality}

Only God has immortality, "It is he alone who has immortality and dwells in unapproachable light, whom no one has ever seen or can see; to him be honor and eternal dominion" (1 Tim 6:16; John 6:46). Immortality is not being subject to death.

At the Second Coming of Jesus, when those who have fallen asleep in Him are awakened, there will be a reunion with those to whom we said "goodbye" at their death.

\footnotetext{
${ }^{1}$ Randolph O. Yeager, The Renaissance New Testament (Gretna, LA: Pelican Publishing, 1985), 17: 412-413.
} 
Now they exult, "Where, $\mathrm{O}$ death, is your victory? Where, $\mathrm{O}$ death, is your sting? The sting ... Thanks be to God, for He has given us the victory through our Lord Jesus Christ" (1 Cor 15:55). It is then that the mystery of the resurrection is revealed just as Paul presented:

Listen, I will tell you a mystery! We will not all die, but we will all be changed, in a moment, in the twinkling of an eye, at the last trumpet. For the trumpet will sound and the dead will be raised imperishable, and we will be changed. For this perishable body must put on imperishability, and this mortal body must put on immortality. When this perishable body puts on imperishability, and this mortal body puts on immortality, then the saying that is written will be fulfilled: "Death has been swallowed up in victory." (1 Cor 15:51-54)

Thus, Paul assures us of the gift of immortality. In his message to the

Thessalonians he spoke about the coming of the Lord and has given us further encouragement to continue the good fight of faith:

We do not want you to be uninformed, brothers and sisters, about those who have died, so that you many not grieve as others do who have no hope. For since we believe that Jesus died and rose again, even so, through Jesus, God will bring with him those who have died. For this we declare to you by the word of the Lord, that we who are alive, who are left until the coming of the Lord, will by no means precede those who have died. For the Lord himself, with a cry of command, with the archangel's call and with the sound of God's trumpet, will descend from heaven, and the dead in Christ will rise first. Then we who are alive, who are left, will be caught up in the clouds together with them to meet the Lord in the air; and so we will be with the Lord forever. Therefore encourage one another with these words. (1 Thess 4:13-18)

John also gives us this assurance which he associates with the tree of life.

Then the angel showed me the river of the water of life, bright as crystal, flowing from the throne of God and of the Lamb through the middle of the street of the city. On either side of the river is the tree of life with its twelve kinds of fruit, producing its fruit each month; and the leaves of the tree are for the healing of the nations. (Rev 22:1, 2) 
When we get into paradise the Tree of Life will sustain immortality, even as it was intended to do in the Garden of Eden (Gen 3:22-24). ${ }^{1}$

As we minister to the needs of those around us whose loved ones are resting in the grave, we are compelled to meet their need by sharing with them our hope in the four gifts of God-reconciliation, resurrection, eternal life and immortality.

It is because of their personal faith in Jesus' death and resurrection that God will resurrect those who died in Him. For this reason, we can declare to others that, "by the word of the Lord, that we who are alive, who are left until the coming of the Lord, will by no means precede those who have died... Then we who are alive, who are left, will be caught up in the clouds together with them to meet the Lord in the air; and so we will be with the Lord forever. Therefore encourage one another with these words" (1 Thess $4: 15-18)$.

For many people there is a need to see or experience the everyday interaction between humanity and divinity in the journey of life with all of its peaks and valleys. For one person the loss of a loved one is just one of the many losses that one encounters in this life. For others it may be an overwhelming event. Therefore a biblical example is needed to reveal the relationship and how it really works to have faith in God and allow Him to work out one's salvation. Abraham's life is a model for us to consider when we speak about the faithful. There are specific aspects of his life as a biblical role model

\footnotetext{
lu The fruit of the tree of life in the Garden of Eden possessed supernatural virtue. To eat of it was to live forever. Its fruit was the antidote of death. Its leaves were for the sustaining of life and immortality." E. G. White, My Life Today (Washington, DC: Review and Herald, 1952), 355.
} 
when it comes to death, separations, losses, and grief that will draw attention to how God is involved and present in community.

\section{A Biblical Role Model - Abraham}

In Gen 12-25 we enter into the experience of Abraham and understand how he dealt with his sufferings. Abraham's life begins for us at the age of seventy-five when he receives a call from God to leave his father's house and go to a place that he would be shown. This is an interesting, yet challenging request. We envision him leaving his homeland, Ur of the Chaldees, but he is not alone in his departure; his father Terah; wife Sarai; and nephew Lot are a part of the caravan as they journey to the land of Canaan in search of the "promised land." He leaves behind the grave of his brother Haran (Lot's father) who died suddenly; and his brother Nahor who chooses to remain in Ur. At the border of Canaan (in Haran) Terah dies (11:31-32). In spite of these two deaths the family entered Canaan.

As we explore Abraham's one hundred years in Canaan and his relationship with God, we will walk with him through the shadows of his sufferings. As an alien in a foreign land we will see him interacting and interrelating with family members, slaves and countrymen. Let us consider this question in the back of our minds as we begin our journey through Gen 12:1 - 25:11. "How does Abraham's suffering serve as a model for us today in dealing with deaths, separations, losses, and griefs?"

Let us investigate this faith, for God never changes. With the help of contemporary authors we will observe the faith landmarks provided for us in the life and journey of Abraham. This will enable us to take hold of the spiritual lessons and apply them to our lives today in order to understand how faith produces obedience in 
relationships with God. Therefore, Abraham's sufferings will serve as a biblical model for us in the twenty-first century as we deal with our struggles with deaths, separations, losses and griefs.

The first twenty-five years (Gen 12:4; 21:5) in Canaan were Abraham's most eventful years. We will immediately observe him as he seeks to know God, gain an understanding of the nations around him, and deal with his personal challenges in the areas of spiritual growth and development.

\section{From the Oaks of Moreh to the Hill Country}

As the caravan begins to set up camp among the Oaks of Moreh, the first rest stop in Canaan, Abram silently waits for a sign from God. ${ }^{1}$ Gazing upon the two mountains at a distance, Mount Ebal and Mount Gerizim, whose majestic peaks point to the heavens and testify of God's creative power, Abram wonders about the awesomeness of this God whom he has chosen to obey. The journey was long and tiring; he might well find himself reflecting upon the call God made to him and its promises (12:1). Abram's question may have been, "Lord, is this the place?"

As the sun sets in the west and darkness envelops the caravan, something wonderful happens: for the first time the Lord appears to Abram and says, "To your offspring I will give this land" (12:7). These words brought joy to the heart of Abram and called for a celebration of praise and thanksgiving; they had reached the land that God had promised to show him (12:1). So Abram built an altar to the Lord, who had appeared to him, and they worshiped Him.

\footnotetext{
${ }^{1}$ Bork, 81-82.
} 
For Abram this meant three things: (1) letting go of the past; (2) embracing the present; and (3) planning for the future.

By faith Abraham obeyed when he was called to go out to the place which he would afterward receive as an inheritance. And he went out, not knowing where he was going. By faith he sojourned in the land of promise as in a foreign country, dwelling in tents with Isaac and Jacob, the heirs with him of the same promise; for he waited for the city which has foundations, whose builder and maker is God. (Heb 11:8-10)

His relationship with God had changed. God was no longer just a voice; he had made visual contact and he could believe in Him and trust His word.

This three-fold sequence similar to Glasser's (see page 6) is echoed in Paul's letter to the brothers and sisters in Philippi relative to breaking with the past.

Not that I have already obtained this or have already reached the goal; but I press on to make it my own, because Christ Jesus has made me his own. Beloved, I do not consider that I have made it my own; but this one thing I do: forgetting what lies behind and straining forward to what lies ahead, I press to the goal for the prize of the heavenly call of God in Christ Jesus. (Phil 3:12-14)

\section{Famine, Sojourn to Egypt, and Sarah in Pharaoh's Harem}

Disaster struck in the land of Canaan; there was a famine in the land. This changed their goal to the survival of the family. Abram went down to Egypt with Sarai and Lot to reside there until the famine subsided.

Before entering Egypt, Abram became aware of the customs, attitudes, and behavior of the idolatrous Egyptians relative to fair and beautiful women for Pharaoh's harem. ${ }^{1}$

I "The Pharaohs are known to have fancied the fairer complexion of foreign women, and to have secured Libyan, Hittite, Mesopotamian, and Palestinian girls for the royal harem." "Genesis to Deuteronomy," SDA Bible Commentary, 1:298. 
Out of fear for his life, Abram and Sarai agreed to use the "sister" aspect of their relationship in an effort to spare his life if they were confronted with this situation. Soon after reaching Egypt it became a reality. Sarai was taken into Pharaoh's house (12:1015). Then Pharaoh lavished Abram with sheep, oxen, male/female donkeys, camels, and male/female slaves (12:16), in exchange for his sister (wife).

What was to follow was unexpected for Abram and Pharaoh: the Egyptians' act of taking possession of another man's wife became a curse. For the Lord afflicted Pharaoh and his house with great plagues because of Sarai (12:3), resulting in Pharaoh's personal dialogue with Abram, returning Sarai to him, and ordering his men to escort them and their possessions to the border. $(12: 17-20)$

\section{Separation from Lot, War, and Rescue}

This trip back to Canaan became full of antipathy because of the wealth Abram and Lot had obtained in Egypt. Their flocks and herds so numerous, there was strife over pasture among their herders. Abram was faced with the inevitable decision, the need for separation between him and his nephew (13:8-13). Abram, Sarai and Lot entered Canaan together as a family unit and now prosperity had driven a wedge between them. ${ }^{1}$ God's command here seems to offer comfort to Abram:

Raise your eyes now and look... [As Abram, in obedience, looks up and around him, in compassion and love the Lord pulls back the veil of time and reveals the future to Abram as if it had taken place in the moment.] For all the land that you see I will give to you and your offspring forever. I will make your offspring like the dust of the earth.... Rise up, walk through the length and the breadth of the land, for I will give it to you. (13:14-17)

\footnotetext{
1 "Abram had given Lot the choice, with extraordinary generosity, all the more generous in a patriarchal situation where Abram was very definitely the head of the Clan. It is anyway a sad decision for Abram: He still has no heir and now loses a possible substitute and family help ... also the most fertile land." Wansbrough, 27.
} 
When Abram returned from his walk with God, he was refreshed and commanded the tribe to break camp. Abram moved his tent and settled again by the Oaks of Mamre and there he built an altar to the Lord (13:18). Once again there was peace, tranquility, and harmony in the camp.

One day Abram had a surprise visit. Mamre, the Amorite and his brothers, Eshcol and Aner (they were allies of Abram), came to the camp with very bad news. Mamre had escaped a raid by King Chedorlaomer. In Mamre's concluding statement he revealed that Lot had been taken captive. Obviously Abram still had a strong love for Lot and his family. Abram gathered his 318 trained servants together with his allies and pursued King Chedorlaomer and his army. When Abram's contingent arrived at Dan they assessed the situation and waited until night to attack. ${ }^{1}$ It appears that this successful mission fulfilled the will of God.

\section{Abraham Faces His Mortality and the Covenant Relationship}

It is evident from the conversation in Chap. 15 that Abram is troubled by his childlessness. Abram is able to speak freely about his fear of dying without an heir. Notice his response in vs. 2, "O Lord God, what will you give me, for I continue childless and the heir of my house is Eliezer of Damascus." God firmly responds to Abram's plea with "no" and proceeds to enlarge on his original call, "to make you (Abram) a great nation" (12:2). This is the first time the Lord specified clearly, "no child but your very own issue shall be your heir" (15:4). To solidify this profound statement, Abram is

\footnotetext{
1 "So in the darkness and the confusion caused by his (Abram's) sudden attack from different quarters, Abram routed the Elamites, recovered the spoil and his captive nephew. With large booty and the rescued Abram returned in peace to the Valley of the Jordan." Dean, 68-69.
} 
escorted outside and told to "look toward the heavens and count the stars. If you are able to count them, so shall your descendants be. Abram believed God and it was reckoned to him as righteousness" $(15: 5,6)$.

God recapitulated the beginnings of their relationship and Abram responded, "O Lord God, how am I to know that I shall possess it (this land)?" $(15: 7,8)$. God seals a covenant with a sacrifice and a vision. The Lord moves within the vision in a way that Abram is rendered powerless and helpless $(15: 12,17){ }^{1} \quad$ This vision is vivid and very pronounced. $^{2}$

There are five prophetic events that will take place relative to this covenant (Gen 15:15-21): (1) Abram will live to a good old age and die; (2) His offspring will be aliens and oppressed slaves for four hundred years; (3) God will bring judgment on that oppressing nation; (4) His offspring shall come back to the land in the fourth generation and possess it from the river of Egypt to the river Euphrates; and (5) The iniquity of the Amorites will be complete.

It is good for us to come to grips with the reality that God knows each of His children very well and makes Himself known to them in different ways, depending on the maturity of the relationship with Him. As we grow in grace He allows us to see different aspects of His character. He may not speak or come to us in tangible ways but we have the assurance of God's presence. Abram at times strayed from God's plan. Even in our weakness God accomplishes His purpose.

1 "This particular 'covenant' is not a mutually binding obligation. A deep sleep (cf. 2:21) falls upon Abraham and only the Lord, represented by a smoking oven and a flaming torch, passes between the animals." Keith H. Essex, "The Abrahamic Covenant." The Master's Seminary Journal, vol 10. no. 2, 201.

2 "Yahweh 'cuts' a covenant with Abraham. The use of this Hebrew word karat ("cut") points us to the inauguration of a new phase of covenant relationships, [it] serves as a guarantee of such confirmation. ... It gives solidity to it and quazi-legal backing for it." Dumbrell, 42. 


\section{Hagar's Marriage, Flight, and the Birth of Ishmael}

In Gen 16 Sarai brings her personal woe to Abraham. Surrogate parenthood was her suggested solution to her grief in her barren condition, so she offers her Egyptian slave, Hagar, as a wife to Abram (vss. 3, 4). ${ }^{1} \quad$ Hagar conceives and looks with contempt on her mistress. Sarai returns to Abram, blaming him and complaining about Hagar, "May the wrong done to me be on you." His response, "Your slave is in your power, do to her as you please," empowers her to reprimand Hagar (vss. 5, 6). Hagar runs away.

This was distressing news for Abram because Hagar could only go to the desert with his child. The drama was short lived when Hagar returned to camp saying she met God. He named her child Ishmael, and revealed his personality and character traits. Hagar submitted to Sarai and bore a son (vss. 7-15). Abram now had an heir and their grief was temporarily resolved.

\section{Abraham Bargains with God over Sodom}

In Gen 18, Abraham had three visitors. Abraham hosted them graciously and one of them revealed himself to be God, promising them the birth of a son. Sarah laughs at the idea, but God said, "Is anything too wonderful for the Lord?" (vs. 14). ${ }^{2}$ Two of the guests proceed on their way but God draws Abraham aside to reveal His purpose for Sodom. The Lord says,

I "Her barren condition was a heavy burden for her, and although being of Abraham's household, she was unable to cooperate in building of that household. Her opprobrium was bitter, like death and nothingness. It was not only a privation of the joy of possession, but a denial of the normal purpose of her existence." Gonzalez, 66.

2 "Sarah [she] laughs at the sheer impossibility of the thing. . . . She is ecstatic at even the thought that, after all these years, she and her husband will experience those transcendent pleasures again." Reardon, 43-45. 
Shall I hide from Abraham what I am about to do, seeing that Abraham shall become a great and mighty nation, and all the nations of the earth shall be blessed? No, for I have chosen him that he may charge his children and his household after him to keep the way of the Lord by doing righteousness and justice; so that the Lord may bring about for Abraham what he has promised.

Then the Lord says to Abraham,

How great is the outcry against Sodom and Gomorrah and how very grave their sin! I must go down and see whether they have done altogether according to the outcry that has come to me; and if not, I will know. (18:17-21)

Abraham appealed to the Lord for mercy, obviously full of concern for Lot and

his family.

Will you indeed sweep away the righteous with the wicked? Suppose there are fifty righteous within the city will you sweep away the place and not forgive it for the fifty righteous who are in it? Far be it from you to do such a thing, to slay the righteous with the wicked. Far be it from you! Shall not the Judge of all the earth do what is just? (18:23-25)

The Lord in His compassion responds, "If I find fifty righteous in the city, I will forgive the whole place for their sake" (18:26). Abraham bargains from fifty, to forty-five, to forty, to thirty, to twenty, and finally to ten. God's response, "For the sake of ten I will not destroy it" (18:28-33). The thought of eradication of Lot's family along with the Sodomites is a source of great concern for Abraham and believing in God's justice he allows God to go on His way.

"Abraham went early in the morning to the place where he had stood before the Lord; and he looked down toward Sodom and Gomorrah and toward all the Land of the Plain and saw the smoke of the land going up like the smoke of a furnace" $(19: 28,29)$. Abraham must have believed that God spared Lot and his family as he looked at the catastrophe. So it was that, when God destroyed the cities of the Plain, God remembered Abraham, and set Lot out of the midst of the overthrow" (19:29). 
Much later when Jesus sojourned on Earth, in His Luke 17 conversation relative to the coming of His Kingdom, He refers to this time and says, "Likewise as it was also in the days of Lot ... on the day when Lot went out of Sodom it rained fire and brimstone from heaven and destroyed them all." The Apostle John in the Book of Revelations picks up the prophecy (Rev 19:20;20:10,15;21:8) as the finale of the great controversy. All who are not written in the Book of Life will have their part in this lake of fire and brimstone, which is the second death. ${ }^{1}$

\section{Abimelech's Court, the Birth of Isaac, Hagar and Ishmael Sent Away}

From there Abraham settled between Kadesh and Shur (Gen 20 and 21).

Abraham has a second faith failure over Sarah's safety but God intervenes with the heathen king, Abimelech. God gives King Abimelech a dream that announced Abraham as a "prophet" with the power to pray for him, "Now then, return the man's wife; for he is a prophet, and he will pray for you and you shall live" (20:7). When Abimelech tells Abraham the dream, Abraham confesses his sin. Sarah is returned to Abraham with gifts. Abraham prays for healing of Abimelech's household. In response God opened the wombs of the women in Abimelech's household and they bear children.

Some time after this Sarah conceived and bears Isaac. Sarah acknowledged God's blessing with the words, "God has brought laughter for me; everyone who hears will laugh with me. Who would have said to Abraham that Sarah would nurse children? Yet I have borne him a son in his old age" $(21: 6,7)$.

1 "The Lake of fire is the last description of the Bible of final punishment. The fiery lake of burning sulphur does not appear anywhere else in the Bible. Even so, conditionalists and traditionalists agree that it stands for the same ultimate destiny which in the Gospels (but nowhere else in Scripture) is pictured under the name of 'Gehenna."' Fudge, 191. 
Now there were two heirs, Ishmael and Isaac. This created a problem for Sarah. So upon seeing Ishmael scoffing at Isaac she immediately goes to Abraham and says, "Cast out this slave woman with her son; for the son of this slave woman shall not inherit along with my son Isaac" (21:10). ${ }^{1}$

The Bible says, "The matter was very distressing to Abraham on account of his son [Ishmael]" (21:11). God's grief ministry was, "Do not be distressed because of the boy and because of your slave woman; whatever Sarah says to you, do as she tells you, for it is through Isaac that offspring shall be named for you. As for the slave woman, I will make a nation of him also, because he is your offspring" $(21: 12,13)$. The obedience of Abraham is the key to his relationship with God. Abraham provided bread and a skin of water, and then sent them off (21:14).

\section{Isaac on Mount Moriah and Sarah's Death}

It would seem that small trials and tribulations in life are preparation for the big challenge. God tested Abraham by commanding him to offer his son Isaac as a sacrifice on a mount in the Land of Moriah in Chap. 22. Abraham did not hesitate; he rose early that morning, collected the sacrificial accessories, saddled his donkey, took Isaac and two young lads, and journeyed for three days in search of "the place."

There appears to be silence between father and son as Abraham anticipates the crisis. When Abraham sees his destination in the distance, he says to his servants, "Stay

\footnotetext{
${ }^{1}$ Sarah seeing the two brothers together realized . . . if they were too alike then Ishmael would pose a threat to Isaac's inheritance. She knew Abraham's positive feeling toward his firstborn son. Isaac's clear identity was at stake, and in Sarah's eyes Isaac could not grow up to be himself if Ishmael, his other side, was constantly present. Cohen, 71-73.
} 
here with the donkey; the boy and I will go over there; we will worship, and then we will come back to you"1 (22:5). Apparently Abraham is taking a leap of faith.

As they walk along together, Isaac senses in his father the intense pain. In his innocence he inquires, "'Father!' The fire and the wood are here, but where is the lamb for the burnt offering?" (22:7). Abraham once again responds in faith, "God Himself will provide the lamb for a burnt offering" (22:8). At the chosen site Abraham builds the altar, places the wood on top and Isaac on top of the wood. He raises the knife, "but the angel of the Lord called to him from heaven, and says, 'Do not lay your hand on the boy or do anything to him, for now I know that you fear God, since you have not withheld your son, your only son from me"" (22:12). ${ }^{2}$ At this point the prophecy of Gen $22: 8$ is fulfilled immediately, for Abraham sees a ram in the thicket caught by his horns. This ram became the substitute sacrifice. God delivered him from his emotional anguish.

By myself I have sworn, says the Lord: Because you have done this ... I will indeed bless you, and I will make your offspring as numerous as the stars of heaven and as the sand that is on the seashore. And your offspring shall possess the gate of their enemies, and by your offspring shall all the nations of the earth gain blessing for themselves, because you have obeyed my voice. (22:15-18)

The next big event in the life of Abraham is the death of Sarah. He mourns and weeps for her. He purchased the burial cave from his Hittite neighbors. The sympathetic Hittites complied with his wishes.

\footnotetext{
1 "Nothing could seem more incongruous than that God would ask Abraham to sacrifice his son. Apart from the revulsion at such an idea and the natural affection of Abraham for the son whose coming was so long awaited, the son is the very heart of the covenant promise. If he dies, the covenant is empty and the promises meaningless. The highest paradox is that God himself demands the sacrifice." Garrett, 167.

2"Justified or not, suffering is always suffering, and explaining it at a human level does not solve anything. ... God's answer to suffering is His own suffering . . . and deliverances from it." Doukhan, 13.
} 


\section{Isaac's Marriage, Abraham's Remarriage, and Abraham's Death}

In Gen 24, Abraham is well up in years and is concerned that his son does not acquire a heathen wife. So he entreats his trusted servant Eliezer to swear that if he dies he will not get a wife for Isaac from the daughters of the Canaanites. So Eliezer goes to Ur of the Chaldees where the family originated, stops by the city well and prays a prayer that is immediately answered. Rebekah, who is of the linage of Abraham's brother Nahor, is the one who, in answer to his prayer, provides water $(24: 15-21)$. After he showers her with gifts and requests lodging, she gets her brother Laban who invites Eliezer home. Eliezer relates his mission to get a wife for Isaac. Laban and Bethuel (Rebecca's father) answered, "The thing comes from the Lord; we cannot speak to you anything bad or good. Look, Rebekah is before you, take her and go, and let her be the wife of your master's son, as the Lord has spoken" (24:50).

Rebekah, with the family's blessing, and her nurse went with Abraham's servant and his men. Isaac immediately receives her, marries her, and is comforted of his grief for his mother $(24: 62-67){ }^{1}$

Abraham remarries, has six sons and grandchildren but he gives them all gifts and sends them all away. This was Abraham's gift to Isaac; there was no one to share his inheritance (25:1-6).

Abraham died at a good old age of 175 . Henry Gaubert gives us this epilogue:

Abraham's religious life, which governs the future spiritual evolution of the Chosen People, was marked by three events of great significance: Firstly, the choosing of Abraham by the Lord. Next, the Covenant made between God and Abraham (and his descendants). Lastly, Abraham's faithfulness. His was integral, unshakable faith, a whole-hearted acceptance of the mission entrusted to him by

\footnotetext{
${ }^{1}$ Ochs, 66.
} 
God. Abraham's earthly life was over. The history of the Chosen People now began. ${ }^{1}$

One legacy that Abraham left behind is this three-step model: Letting go of the past, embracing the present, and planning for the future. (See Glasser's paradigm on page 6.) He demonstrated this model the day he entered Canaan until his death (Gen 12:1-4; 25:5, 6). From this model one might mistakenly conclude that the process is completed in a few days. But in fact, it can take a number of months or longer and vary from person to person.

Let us turn to chapter 3 to look at personal and community rituals that facilitate grief. For our examples we will observe the death of Jacob from the Old Testament; and, Ellen G. White's grief relative to the death of her sons and her husband.

\footnotetext{
' Gaubert, 184.
} 


\section{CHAPTER III}

\section{PERSONAL AND COMMUNITY RITUALS THAT \\ FACILITATE GRIEF}

Suffering is one of the most painful challenges we face as human beings. The purpose of this chapter is to provide a foundation of personal and community rituals that facilitate grief and allow us to build a viable structure for a Grief Ministry Program in the local Seventh-day Adventist church and its community. We begin by observing this process in one of its earliest examples in the biblical community and compare this with the personal and community rituals of today. For a biblical model of grief we will use the death of Jacob; and, from the Spirit of Prophecy, we will use the deaths in Ellen G. White's immediate family. Solomon reminds us, "The living know that they will die ..." (Eccl 9:5). Direct quotations will be used where essential; otherwise events will be summarized because of their length.

\section{Biblical Rituals That Facilitate Grief - Death of Jacob}

Jacob and his family moved down to Egypt with the blessing and promises of God, "Jacob, Jacob, I am God, the God of your father; do not be afraid to go down to Egypt, for I will make of you a great nation there. I myself will go down with you to Egypt, and I will also bring you up again; and Joseph's own hand shall close your eyes" (Gen 46:1-4). 
They settled in the land of Rameses, the region of Goshen, according to the instructions of Pharaoh. After their arrival, Joseph took his father to meet Pharaoh. It is interesting to note that as they met, Pharaoh looked upon Jacob with wondering eyes and asked, "How many are the years of your life?" (47:8). In Jacob's response we get a glimpse of the longevity of those who lived during those days. "The years of my earthly sojourn are one hundred thirty; few and hard have been the years of my life. They do not compare with the years of the life of my ancestors during their long sojourn" (47:9). At death Isaac was 180 years old (35:28); Abraham was 175 years old (25:7); Terah was 205 years old (11:32); and Nahor was 219 years old (11:24). Then Jacob blessed Pharaoh and went out from his presence (47:10).

The last days of Jacob came when he was 147 years old, 17 years after arriving in Egypt. We now give consideration to the process that took place during the last days of Jacob's life, which can serve as a model of grief rituals that facilitate grief for us.

Jacob's Last Request and Instructions would be what we would call a Verbal Will given to Joseph personally shortly before his actual death. He gave him instructions about the disposition of his body.

1. Verbal Will and Testament. He called his son, Joseph, and said to him, "If I have found favor with you, put your hand under my thigh and promise to deal loyally and truly with me. ${ }^{1}$ Do not bury me in Egypt. When I lie down with my ancestors, carry me out of Egypt and bury me in their burial place." And he (Joseph) said, "I will do as you

\footnotetext{
${ }^{1}$ The hand under the thigh is an ancient custom, chapter 24:1-3, "Abraham ... said to the chief servant in his household, the one in charge of all that he had. 'Put your hand under my thigh. I want you to swear by the Lord, the God of heaven and the God of earth, that you will not get a wife for my son from the daughters of the Canaanites, among whom I am living, but will go to my country and my own relatives and get a wife for my son Isaac." "Genesis to Deuteronomy," SDA Bible Commentary, 1: 474.
} 
have said." And he (Jacob) said, "swear to me"; and he (Joseph) swore to him. Then Israel bowed himself on the head of his bed ${ }^{1}$ (47:29-31).

\section{Personal Notification. Personal notification was made when they sent for}

Joseph and he came immediately. ${ }^{2}$ In most cases when the immediate family senses that death is imminent, they begin to notify other family members to come without delay to see their loved one while he or she is still alive.

3. Family Gather Around Bedside. Joseph was told, "Your Father is ill" (48:1). So he took with him his two sons, Manasseh and Ephraim. When Jacob was told, "Your son Joseph has come to you," he summoned his strength and sat up in the bed. $\mathrm{He}$ shared with him God's vision to him with its promises (48:3-5); claimed his two sons as his with inheritance equal to that of Reuben and Simeon; and, spoke of his love for Rachel whom he buried on the way to Ephrath. When Israel saw Joseph's sons, he asked Joseph to bring them to him, he kissed them, embraced them, and blessed them. ${ }^{3}$ These are his last words to Joseph, "I am about to die, but God will be with you and will bring you a gain to the land of your ancestors. I now give to you one portion more than to your

\footnotetext{
1 "This is an accurate translation of the Hebrew text as vocalized by the Jewish scholars, the Masonretes, in the $7^{\text {th }}$ century.... Accordingly, they translated the passage, 'Israel bowed himself on the top of his staff.' Since the action of leaning on his staff while doing obeisance to God would be quite suitable to Jacob's age and infirmity as turning over and bowing on the head of his bed. ... Whatever the exact position of the patriarch, it was a posture of devotion in which he poured out his soul in grateful adoration to God." lbid., 475.

2 “'Thy Father is sick.' Not long after the visit of Joseph, at which Jacob made arrangements for his burial, Joseph was informed of his father's final illness. He immediately went to him with his two sons, Manasseh and Ephraim, who were between 19 and 25 years old (see v. 5; chs. 47:28; 41:50; 45:6)." Ibid., 476.

3'،'His right hand.' This is the first Scriptural record of the imposition of hands being a symbol of blessing. Though not essential to the transmission of blessing, the act is not without appropriate fitness as being a symbol of the invisible fact. Accordingly, it became the recognized mode of conveying spiritual powers, or gifts." lbid., 476.
} 
brothers, the portion that I took from the hand of the Amorites with my sword and with my bow" (48:21-22).

4. Family Charge and Blessing. Family charge and blessing are done at the bedside when all of the family members are gathered around. Many times the dying person speaks in a prophetic voice to the living. Then Jacob called his sons, and said: "Gather around, that I may tell you what will happen to you in days to come"" (49:1-28). Then he charged them, saying, "I am about to be gathered to my people. Bury me with my ancestors - in the cave in the field of Ephron the Hittite, in the cave in the field at Machpelah, near Mamre, in the land of Canaan, in the field that Abraham bought from Ephron the Hittite as a burial site" (49:29-33). When he had ended his charge to his sons, he drew up his feet into the bed, breathed his last, and was gathered to his people.

\section{Personal Mourning Is the Outward Expression of the Grief Felt Inside. Then}

Joseph threw himself on him (Jacob) and kissed him. ${ }^{2}$

\section{Embalming Was Not the Practice of the Israelites. ${ }^{3}$ Joseph commanded the} physicians in his service to embalm his father. So the physicians embalmed Israel; they

\footnotetext{
l's'Jacob called unto his sons.' Jacob now revealed to his 12 sons his spiritual bequest. Solemnly he exhorted them to listen to the things he was about to say. As Isaac, by virtue of divine foresight, had in his blessing (ch. 27) pointed out prophetically to Jacob and Esau the future history of their families, so in broad outline the future of the entire nation, as represented by the 12 sons, was pictured by Jacob. To each he assigned its position and importance in the nation, with unerring prophetic insight." Ibid., 479.

${ }^{2}$ '“' Joseph fell upon his father's face.' Joseph had no doubt closed the eyes of his beloved father, as God had promised (ch.46:4). That only Joseph's grief is described in this passage does not imply that the other sons did not sorrow for their father... . The grief of Joseph is representative of the grief of all, and we may assume that their sorrow was just as real." Ibid., 485.

3 "In the matter of death and burial, as in other matters, the eastern rabbis looked for guidance to the first great record of rabbinic teachings, the Mishnah. So they knew that, according to the Judaism they deemed right, the dead had to be buried immediately, not only in contact with but actually in the ground. After approximately a year, the bones of the deceased should be gathered and reburied, again under the surface of the earth. Unburial was a sin and more: if the protection of the grave did not eliminate the pains of death, how much worse would the pains of unburial have been!" David Kraemer, The Meaning of Death in Rabbinic Judaism (New York: Routledge, 2000), 95.
} 
spent forty days in doing this, for that is the time required for embalming. The Egyptians wept for him seventy days.'

\section{Fulfillment of Last Will and Testament of Jacob Included the Interment. ${ }^{2}$ When}

the seventy days of weeping for him were past, Joseph addressed the household of

Pharaoh and told them his father's request. Pharaoh answered, "Go up, and bury your father, as he made you swear to do" (50:6). So Joseph went up to bury his father . . with a very great company. When they came to the threshing floor of Atad, which is beyond the Jordan they held there a very great and sorrowful lamentation; and he observed a time of mourning for his father seven days.

8. Community Mourning. Community mourning is not unusual. When someone dies the community feels the pain of the loss although they are not directly associated with the family. No man is an island, no man stands alone. A funeral train is acknowledged and respected as the procession moves through a community en route to the cemetery or burial spot. It was not unusual for other communities to become involved with the grief of a nation. When the Canaanites, inhabitants of the land, saw the mourning on the threshing floor of Atad, they said, "This is a grievous mourning on the part of the Egyptians." They were impressed by this unusual event and entered into the

\footnotetext{
1"Mummification is the preservation of a body, either animal or human. The ancient Egyptian mummification process took 70 days. . . . After death; the pharaohs of Egypt were mummified and buried in elaborate tombs. Members of the nobility and officials also often received the same treatment, and occasionally, common people." Brier and Hobbs, 47-53.

2"My father made me swear an oath; he said, "I am about to die. In the tomb that I hewed out for myself in the land of Canaan, there you shall bury me.' Now therefore let me go up, so that I may bury my father; then I will return' (50:5). Jacob's claim has been criticized as a contradiction of facts presented in ch. 23." "Genesis to Deuteronomy," SDA Commentary, 1:484-486.
} 
mourning of this dignitary. ${ }^{1}$ Because of the intensity of the grieving, the place was named Abel-mizriam: it is beyond the Jordan. ${ }^{2}$

9. Burial/Interment. Burial or Interment is the process of placing the body in a grave or tomb. This could be considered the finale of the deceased's life on earth. Thus Jacob's sons did for him as he had instructed them. They carried his body to the land of Canaan and buried him in the cave of the field at Machpelah, the field near Mamre, which Abraham bought as a burial side from Ephron the Hittite.

10. Return to Everyday Life Is the Expectation for Those Who Are Bereaved. Life goes on. _After he had buried his father, Joseph returned to Egypt with his brothers and all who had gone up with him to bury his father.

We have witnessed in these few verses (Gen 49:29-50:14) the personal and community rituals that facilitate grief handed down to the twelve tribes of Israel by Jacob their father. This included Verbal Will/Testament; Personal Notification; Family Gathering Around Bedside; Family Charge and Blessing; Personal Mourning; Embalming; Fulfillment of Last Will and Testament; Community Mourning; Burial/Internment; and, the Return to Everyday Life.

\footnotetext{
l's"The threshing floor of Atad.' The threshing floor was a large open area for the trampling out of grain by oxen, and was most convenient for the accommodation of a large body of people such as accompanied Joseph. Atad was either the name of the owner or, since 'atad' is the Hebrew name for buckthorn, it may have indicated that buckthorn grew abundantly. There they mourned for seven ... for a special mourning the inhabitants of the surrounding countryside where much impressed by the way the Egyptians mourned the father of one of their dignitaries. The unusual event was the reason the Canaanites of that region call the place Abel-mizraim, the 'meadow of Egypt.' This name represents a play on the words, 'mourning,' 'ebel' and 'meadow,' 'abel,' both having the same consonants." Ibid., 486.

2's'Beyond Jordan.' The funeral procession did not take the shortest route, by Gaza, through the country of the Philistines, nor through Beersheba, but around the Dead Sea. The reasons for this long detour are unknown, but many have been political. Very little is known of the genral relations between Egypt and Palestine during the period of the Hyksos, and a state of insecurity in southern Palestine may have been responsible for the extraordinary route Joseph took to reach Hebron." Ibid., 486.
} 
These personal and community rituals that facilitate grief have become a part of the Grief Ministry outlined in the Bible narrative of Jacob's final days. They serve as a basic model utilized by most Christians with some creativity.

\section{Spirit of Prophecy Rituals That Facilitate Grief - Death of John Herbert, Henry Nichols, and James Springer White}

The best way to understand the personal and community rituals that facilitate grief in the Spirit of Prophecy is to observe Ellen G. White. The Seventh-day Adventist Church acknowledges her spiritual giftedness in meeting all the tests of a true prophet as set forth in Holy Scripture.

Ellen G. White was a wife and mother. As we peruse her writings we will observe how she understood and utilized the grieving process to recover, minister, and model behavior and attitude during her loss of loved ones closest to her. We will also draw from the previous grieving models, Abraham and Jacob, to provide a frame from which to work through the White family process. Clarence C. Crisler made this observation relative to her life:

Whatever the cross she was called to bear, whether the said misfortunes of early childhood, the bitter privations incident to pioneer life, the scathing ridicule and the scornings of a gainsaying public, the loss of her cherished babe and her firstborn, the unexpected and sudden death of her husband in 1881 , or the long and painful sicknesses that came to her in strange lands and under most trying circumstances, these all caused her to reach a little higher and to lay hold a little more firmly on the help of heaven promised every trustful soul. ${ }^{1}$

What we are seeking to do here is to pull together the physical, mental, emotional, spiritual attitudes and behaviors surrounding the events and circumstances of her grief.

\footnotetext{
'Clarence C. Crisler, "The Death of Sister White," Pacific Union Record, July 22, 1915.
} 
From this vantage point we can receive guidance that will provide personal and community rituals which will move the bereaved toward health and healing.

For our consideration, it is paramount to recognize the ages of her loved ones who preceded her in death, and their relationship to her. This will provide a model of the grieving process relative to dying and death at every stage of growth and development infancy, youth and adult (spousal). We would be amiss if a disclaimer was not stated at this point. Taking into account Ellen G. White's spiritual attainments, her response to grief was not untypical but may not always represent what others have experienced. Be assured that she was in touch with her grief and pain. She dealt with it and has left some personal and community rituals that facilitate grieving.

In the book, Pastoral Ministries, we find the following comment regarding counseling those in grief, which came at a very tender moment in her life, "Grief can make the strong despondent. After we returned from the funeral, my home seemed lonely. I felt reconciled to the will of God, yet despondency and gloom settled upon me." This statement refers to Ellen White's experience in speaking of the death of her fourth child, three-month-old John Herbert White who was born on September 20, 1860, and died December 14, $1860 .^{2}$

John Herbert's death followed the premonition received by his father, James White, while praying for the family at home. This was prior to John's ensuing illness that resulted in his suffering and death. In a letter Ellen White received from James written

\footnotetext{
${ }^{1}$ Ellen G. White, Pastoral Ministries (Silver Spring, MD: Ministerial Association of the General Conference of SDA, 1995), 217.

${ }^{2}$ Ellen G. White, Testimonies for the Church, 9 vols. (Mountain View, CA: Pacific Press Pub. Assn., 1855-1868), 1:244-245.
} 
while in Mackford, Wisconsin, it said, "I fear that all is not well at home. I have some impressions as to the babe." When she received the letter, the child was well as usual; but the next morning he was taken very sick. It was an extreme case of erysipelas in the face and head. ${ }^{2}$ In her telegram to him when he reached Brother Wick's, near Round Grove, Illinois, he told those present that he was not surprised at the news, for the Lord had prepared his mind for it, and that they would hear that the child's head and face was greatly affected.

As Ellen White expounded on this sudden crisis, she said, "My dear babe was a great sufferer." ${ }^{3}$ However, his twenty-four days and nights of suffering were not without its emotional drain on Ellen. She says, "I could not control my feelings as I witnessed his sufferings. Much of my time was spent in tears and humble supplication to God. But our heavenly Father saw fit to remove the loved one."4

Personal Notification/Moment of Death:

December 14 he was taken worse, and I was called up. As I listened to his labored breathing and felt his pulseless wrist, I knew he must die. The icy hand of death was already upon him. That was an hour of anguish for me. We watched

1 "In mid-November, Ellen had taken the children by train to the country and stayed with the Glover family.... It must have been in connection with this trip that the virulent germs of erysipelas, to which infants are very susceptible, were picked up. It must have been during this three-week period that the child was given a name--John Herbert White." Arthur L. White, Ellen G. White: The Early Years 18271862 (Hagerstown, MD: Review and Herald, 1986), 430.

2 "Erysipelas: Contagious inflection of the skin and underlying tissue, caused by grop A Bhemolytic streptococcus bacteria. Erysipelas causes affected areas of skin to turn bright red and become slightly swollen. The swollen blotches have a distinct border and slowly expand into the surrounding skin. The lesions are most commonly seen in the face, scalp, hands and legs. They feel hot to the touch and the patient is feverish. Centuries ago erysipelas epidemics caused severe and often fatal infections. Today erysipelas is a rather mild and relatively rare infection that clears up rapidly when penicillin or other antibiotics are taken." The Catholic Community Forum, http://www.catholicforum.com/saints/pst00262.htm, (May 2005).

${ }^{3}$ E. G. White, "Beware of the Spare Bed," Review and Herald, January 2, 1872, 1.

${ }^{4}$ E. G. White, Testimonies for the Church, Vol. 1 (Mountain View, CA: Pacific Press Pub. Assn., 1948), 1:245. 
his feeble, gasping breath until it ceased, and could not but feel thankful that his sufferings were ended.'

Individual Mourning:

"When my child was dying, I could not weep. My heart ached as though it would break, but I could not shed a tear."2

Community Mourning:

Funeral - James White delivered the eulogy. Ellen fainted. ${ }^{3}$

Burial:

Interment - Oak Hill Cemetery. ${ }^{4}$

Return to Everyday Life:

After we returned from the funeral, my home seemed lonely. I felt reconciled to the will of God, yet despondency and gloom settled upon me. We could not rise above the discouragements of the past summer. . . While my child lived; I thought I understood my duty. I pressed my dear babe to my heart and rejoiced that at least for one winter I should be released from any great responsibility, for it could not be my duty to travel in winter with an infant. But when he was taken from me, I was again thrown into great perplexity. ${ }^{5}$

It seems that James and Ellen had their ministerial work cut out for them. Satan had gained control of the minds of some who were closely connected with them in the work. The condition of God's cause and people nearly crushed them. The work revived through the fervent prayers of the brethren. Ellen had a vision of the work and a message

\footnotetext{
${ }^{1}$ Ibid., 1:246.

${ }^{2}$ Ibid.

${ }^{3}$ Ibid.

${ }^{4}$ Ibid.

${ }^{5}$ Ibid.
} 
that God's servants must bear a pointed testimony, which will cut the natural heart and develop character.

For three years James and Ellen labored diligently and the work of the Lord advanced but not without taking its toll on the Whites. In December 1863 tragedy struck again. Sixteen-year-old Henry Nichols, their oldest son, was taken sick with lung fever and rapidly failed. Within a week he was dead and buried. It is from this seven-day crisis that we get an overview of the mental, emotional, physical and spiritual trauma the White family endured as they experienced and witnessed the dying and death of Henry. When we speak about having a family session where the dying person has an opportunity to recapitulate their life, this is a "life review" brought to us by a teenager.

In the 1888 book, Life Sketches of James White and Ellen G. White, Sister Adelia P. Patten, who had been a faithful and devoted member of the family for about two years, wrote a brief sketch of the life, experience, and last sickness of their son, Henry Nichols. ${ }^{2}$ She referred to him as the much-loved and much-lamented son. Background:

December 1, (1863) - He [Henry] was taken sick with lung fever, and rapidly failed. From his room in the chamber he was carried into one of the lower rooms

${ }^{1}$ Ibid., 1:246-249.

${ }^{2}$ Henry was born in Gorham, Maine, August 26, 1847. In December he was taken sick with inflammation of the lungs, and all who saw him thought his recovery doubtful. One evening he appeared to be fast failing, and it seemed that he must die. It was then; when all earthly means failed, that his parents presented his case before the great physician, trusting in his power and willingness to save their beloved child. They spent much of the night in prayer, and while pleading with God to spare his life, he fell into a sweet sleep, and from that hour began to recover. Ellen G. White, Life Sketches, Ancestry, Early Life, Christian Experience, and Extensive Labor of James White and Ellen G. White (Battle Creek, MI: Steam Press of SDA Publishing Assn., 1888), 342-350. 
- the very one, where sixteen years before, when but an infant, he was apparently brought to the point of death. ${ }^{1}$

Spiritual Preparation:

December 2 - His mother said to him that life was uncertain and that persons violently attacked as he had been were frequently deprived of their reason, and if he had any thing to say, he had better improve the present opportunity. He said that he felt unprepared to die, and requested his parents to pray for him. After they had prayed for him he called his brothers to him, embraced them, and told them he had not always treated them as a brother should have done, and wept as he asked their forgiveness. In the evening the family had a season of prayer in his room pointing to the sinner's friend and advocate with the Father; and, was so encouraged to rely wholly upon the merits of Christ. Then Henry, with deep feeling repeated these lines several times, "Here, Lord, I give myself away, 'tis all that I can do."

Last Will and Testament:

December 3 - His friends were alarmed by the discharge of blood from his nose and mouth. From this time forward he expressed but little desire to get well. $\mathrm{He}$ said to his mother, "Promise me, mother, that if I die, I may be taken to Battle Creek, and laid by the side of my little brother, John Herbert, that we may come up together in the morning of the resurrection."

Life Review:

December 4-He carefully reviewed the events of his life, mourning over his imperfections, still pleading with God for pardon and acceptance. From this time he seemed to enjoy peace of mind and the blessing of God. He often requested his parents to pray for him, not that he might get well, but that he might feel his acceptance with God every moment. He grew weaker, and could not speak above a whisper. ${ }^{4}$

1 "During the absence of their parents, Henry and Edson, under the supervision of Brother Howland, were busily engaged in mounting the charts on cloth, ready for sale. They worked in a rented store building and a block from the Howland home. At length they had a respite for a few days while they were waiting for charts to be sent from Boston.... Returning from a long tramp by the river, he [Henry] thoughtlessly lay down and slept on a few damp cloths used in backing the paper charts. A chilly wind was blowing in from an open window. This indiscretion resulted in a severe cold. Authur L. White,

Progressive Years 1863-1875, 70-72.

${ }^{2}$ E. G. White, Life Sketches, 344.

${ }^{3}$ Ibid., 346.

${ }^{4}$ Ibid. 
A Parent's Prayer and Surrender/Letting Go:

December 5-Burdened with grief, his father [James] retired to a place of prayer and afterwards returned to the sick-room feeling the assurance that God would do all things, well, and thus expressed himself to his suffering son. At this his countenance seemed to light up with a heavenly smile, and he nodded his assent and whispered, "Yes, He will."

Charge and Testimony:

December 6-He said that he had enjoyed more of the blessing of God during the past two days than ever before in all his life. He felt that he could not live long, and wished to leave a few sentiments for the young, which dictated as follows.... "I would appeal to all my young friends, not to let the pleasures or accomplishments of this world eclipse the loveliness of the saviour. Don't take my life for an example; give up the world and be Christians."

In the evening he inquired of his brothers, and as they came to his side he said, "Don't mourn after I am dead." Henry felt anxious lest some one might be away weeping, and inquired for his mother, saying, "O my dear mother, may God comfort her." He called his father and said, "Father, you are losing your son." Since music had been his greatest earthly pleasure, he asked Edson to play 'Mount Vernon' for him, "Music in heaven will be sweeter than that."2

Submission to the Will of God:

December 7 - He expressed a wish to die, fearing that if he lived he would not be able to escape the many dangers to which the young are exposed. His father told him he must be submissive to the will of God; that it would be blessed to live to do good in his service, and blessed to die in the Lord. ${ }^{3}$

Moment of Death/Gathering Around the Bedside:

December 8 - A short time before his death, he said to his mother, "Mother, I shall meet you in heaven in the morning of the resurrection, for I know you will be there." He then beckoned for his brothers, parents, and friends and gave them all a parting kiss, after which he pointed upward and whispered, Heaven is Sweet. These were his last words. His breath grew shorter, and, without a struggle, he sank in death at half-past one o'clock, p.m. His sufferings were over. ${ }^{4}$

\footnotetext{
${ }^{1}$ Ibid.

${ }^{2}$ Ibid., 347.

${ }^{3}$ Ibid., 348.

${ }^{4}$ Ibid., 349.
} 


\section{Fulfillment of Request/Funeral/Community Mourning:}

In compliance with his request, Henry was brought to Battle Creek in a metallic burial casket, and, agreeably to the wishes of many friends, appropriate funeral services were held, and a large congregation was addressed by Elder U. Smith. One interesting feature of the occasion was the order in which the students of the public school, accompanied by the teachers, came to pay their last token of regard for one of their number whom they loved. As the speaker proceeded with his remarks, many in the congregation were moved to tears. One in the bright morning of youth, whose course of life had won their highest regard, had closed his eyes in death, cheered by those sacred hopes and promises whose attractive light ever takes from the joys of earth their delusive brightness. The exercises were closed with singing, by the school, --

'One sweet flower has drooped and faded, One sweet youthful voice had fled, One fair brow the grave has shaded, One dear schoolmate now is dead.'

Burial/Interment:

After the last look had been taken, a large procession of sympathizing friends followed the remains to Oak Hill Cemetery, where the lifeless form of noble Henry was laid by the side of his little brother, there to rest till the lifegiver returns to bring them from the land of the enemy. ${ }^{2}$

Return to Everyday Life:

This is one of the few statements that Ellen G. White expressed regarding Henry's

death, the family's ability to cope with this great loss, and their hope.

But oh, when our noble Henry died at the age of sixteen,--when our sweet singer was borne to the grave, and we no more heard his early song,--ours was a lonely home. Both parents and the two remaining sons felt the blow most keenly. But God comforted us in our bereavements, and with faith and courage we pressed forward in the work He had given us, in bright hope of meeting our children who had been torn from us by death, in that world where sickness and death will never come. $^{3}$

\footnotetext{
${ }^{1}$ Ibid.

${ }^{2}$ Ibid., 350.

${ }^{3}$ Ellen G. White, Life Sketches (Mountain View, CA: Pacific Press, 1915), 165-166.
} 
I was personally touched by Henry's spiritual strength and preparedness for death. It seemed as though it was his ability to articulate his hope that helped pull the family through this tough time. The human heart can only deal with so much pain and suffering. This is one of the concerns that many people face today, especially when a teenager dies. With the two brothers left behind, there may have been a concern about their continued existence. Nevertheless the family was able to pull themselves up and continued the good fight of faith, trusting that God would continue to lead, guide, and direct in their lives.

For eighteen years it seemed that the family was able to deal with their previous family losses and live a somewhat normal life. Willie and Edson got married; and, James and Ellen poured their hearts and souls into their ministry by traveling all over North America.

In 1880 James White resigned from every office except his connection with the publishing work. He moved more into a pastoral role and frequently spoke in the Tabernacle SDA Church in Battle Creek, Michigan. Occasionally he baptized new converts and performed marriages. Little did he know that he was entering the last year of his life.

Life Review, Confession and Forgiveness:

Two weeks before his death James S. White began articulating his thoughts to his wife, Ellen G. White, during their early morning walks through the grove near their home to engage in prayer- these where their "precious seasons.""

1 "My husband [James S. White] often asked me [Ellen G. White] to accompany him to the grove, near our house, to engage with him in prayer. These were precious seasons. Ellen G. White, In Memoriam: A Sketch of the Last Sickness and Death of Elder James White (Battle Creek, MI: Review \& Herald Press, 1881), 46. 
I feel my heart unusually drawn out in earnest longing for more of the Spirit of God. . . But the nearer we come to God, the more we feel our own weakness, and our need of help from above. In God is my strength; in him I shall triumph. ${ }^{1}$

At another time, "A deep solemnity is upon my spirit... I I confess my errors, and ask your forgiveness for any word or act that has caused your sorrow. Everything must be right between us, and between ourselves and God."

Upon another occasion while praying in the grove. ... I desire faithfully to employ my power to promote peace, happiness, and progress in the cause of God. I must cultivate sympathy and patience. With me, to be still requires more grace than to be active in the battle. "Peace, be still!" This is the lesson I must learn. ${ }^{3}$

Traveling with her by private conveyance to Charlotte, Michigan, for an appointment to attend a tent-meeting (Sabbath and Sunday, July 23-24, 1881), he repeatedly praised the Lord for mercies and blessings received; and, freely expressed his own feelings concerning the past and future: ${ }^{4}$

Our labors, burdens, and sacrifices will never be fully appreciated by all. I see that I have lost my peace of mind and the blessing of God by permitting myself to be troubled by these things. It has seemed hard to me that my motives should be misjudged, and that my best efforts to help, encourage, and strengthen my brethren should again and again be turned against me. Had I ever left all my perplexities with the Lord, thinking less of what others said and did against me, I should have had more peace and joy. I love God and his work, and I love my brethren also. ${ }^{5}$

The Last Week of James S. White's Life is recorded here to share with the reader the events as they relate to the grief models we have discussed previously in the chapter.

${ }^{1}$ Ibid., 47.

${ }^{2}$ Ibid.

${ }^{3}$ Ibid., 48.

4 " This was the last journey we would ever make together. My husband [James S. White] took cold, but thought his health so good that he would receive no permanent injury.... Wednesday we returned home. On the way he complained of a headache, his lungs were congested, and he coughed some. We thought the attack only a common cold which would readily yield to treatment. He went about his work as usual, but was troubled with pain in his limbs." Ibid., 51-52.

${ }^{5}$ Ibid., 50-51. 
Sabbath, July 30 (1881):

The Usual Morning Walk in the Grove.

Sabbath morning, as usual, we walked to the grove together, and my husband prayed most fervently three times. He seemed reluctant to cease pleading with God for special guidance and blessing. His prayer was heard, and peace and light came to our hearts. My husband praised the Lord, and said, "Now I give it all up to Jesus. I feel a sweet, heavenly peace, an assurance that the Lord will show us our duty; for we desire to do His will."'

Sunday, (July 31,1881 ), he attended the Eastern camp meetings, and said the Lord could give him strength, if it was his duty to go.

Monday he had a severe chill. ${ }^{3}$

Tuesday he did not rally as expected, but we thought the disease an attack of fever and ague (malaria), and supposed that it would soon yield to treatment. ${ }^{4}$

Wednesday moved to the Sanitarium for treatment under the care of Dr. Kellogg. ${ }^{5}$

Personal Notification - Family and Brethren Gathering at the Bedside:

"Friday the doctors informed me [Ellen G. White who was also in the hospital and her symptoms became more favorable] that my husband [James S. White] was inclined to sleep, and that danger was apprehended [synonym: foreseen]. I was immediately taken to his room, and as soon as I looked upon his countenance I knew that he was dying. I tried to arouse him. He understood all that was said to him, and responded to all questions that could be answered by yes or no, but seemed unable to say more. When I told him I thought he was dying, he manifested no surprise. I asked if Jesus was precious to him. He said, "Yes, oh yes." "Have you no desire to live?" I inquired. He answered, "No."6

\footnotetext{
${ }^{1}$ Arthur L. White, Ellen G. White the Lonely Years 1876-1891 (Hagerstown, MD: Review and
} Herald, 1986), 169.

${ }^{2}$ Ibid.

${ }^{3}$ Ibid.

4 "Tuesday night I [Ellen G. White] was attacked with chills, and was very sick, being unable to sit up on the following day. Dr. Kellogg then proposed that we both be removed to the Sanitarium, where we could enjoy better facilities for treatment. A mattress was placed in the hack, my husband and myself were laid side by side, for the last time, and thus taken to the Sanitarium." Ibid.

\footnotetext{
${ }^{5}$ Ibid.

${ }^{6}$ Ibid.
} 
We then knelt by his bedside, and I prayed for my husband in that solemn hour. A peaceful expression rested on his countenance. I said to him, "Jesus loves you. The everlasting arms are beneath you." He responded, "Yes, yes." I wished to be certain that he recognized us, and I asked him to tell who we were. He said, "You are Ellen. You - looking at our elder son - are Edson. I know you all." Brother Smith and other Brethren then prayed around his bedside and returned to spend much of the night in prayer. ${ }^{1}$

My husband said he felt no pain; but he was evidently failing fast. Dr. Kellogg and his helpers did all that was in their power to hold him back from death [see Appendix D for Dr. Kellogg's report)]. Slowly revived, but continued very weak. I remained with him through the night. ${ }^{2}$

The next morning [Sabbath] he took some nourishment, and seemed slightly to revive. About noon he had a chill, which left him unconscious, and he quietly breathed his life away, without a struggle or groan. I was mercifully spared the anguish of seeing my husband in agony battling with death. The scene was as pleasant as it was possible for a deathbed to be. ${ }^{3}$

Prayer Vigil by Faith Community:

On the balmy afternoon of the Sabbath, August 6, quite a large number of solemnfaced Adventists residing in Battle Creek drifted to the grounds of the Sanitarium and milled around the lobby of the main building. They had come to keep vigil for James White. These were his friends, those with whom he had worked, and members of the church he had pastored. They had come knowing that James White, critically ill at the Sanitarium, had just taken a serious turn for the worse. In the early afternoon the report was whispered that he was unconscious and very near death's door. Not a few were seen to furtively wipe away tears. It was all so sudden, so tragic. ${ }^{4}$

They felt the end must be near. At five-fifteen, the dreaded word came: James

White was dead. The people were stunned. Some called to mind that just a few days before they had read his editorial in the Review carrying the title, "Words of Comfort," dealing with the Christian hope. In this he asked the question, "Is there hope beyond the
' Ibid., 170.
${ }^{2}$ Ibid.
${ }^{3}$ Ibid.
${ }^{4}$ Ibid., 168. 
grave?" Then he cited compelling Scripture evidence that clearly showed that the hope of the gospel dispels the gloom that enshrouds the grave. ${ }^{1}$ Individual Mourning:

Ellen G. White gives this account of her reaction to the reality that her husband was dead:

The shock of my husband's death - so sudden, so unexpected - fell upon me with crushing weight. In my feeble condition I had summoned strength to remain at his bedside to the last; but when I saw his eyes closed in death, exhausted nature gave way, and I was completely prostrated. For some time I seemed balancing between life and death. The vital flame burned so slow that a breath might extinguish it. At night my pulse would grow feeble, and my breathing fainter and fainter till it seemed about to cease. Only by the blessing of God and the unremitting care and watchfulness of physician and attendants was my life preserved. $^{2}$

Community Mourning:

Plans for the funeral called for some delay, for W. C. White and his wife, Mary, were across the continent, almost a week's travel time away. James's brother John, for many years a presiding elder of the Methodist Conference in Ohio, was closer, but might need a little time to arrange to come. Another brother, Samuel, a Baptist minister in Massachusetts, was summoned, but was too feeble to come. A sister, Mary Chase, lived with the Whites in Battle Creek. The funeral was set for Sabbath afternoon (August 13, 1881), just a week after his death. ${ }^{3}$

Funeral:

On Sabbath afternoon, August 13, some 2,500 Seventh-day Adventists and Battle Creek townspeople assembled in the Tabernacle for the funeral of James White.

\footnotetext{
'Ibid.

${ }^{2}$ Ellen G. White, Life Sketches (1888), 252.

${ }^{3}$ Arthur White, The Lonely Years, 173.
} 
The Eulogy was given by Elder Smith. He spoke of James White's activities in connection with the origin and rise of the Seventh-day Adventist Church. As Elder Smith concluded his remarks, Ellen White, quite unexpectedly, arose from her couch to speak to the large audience.'

Interment:

Ninety-five carriages joined in the funeral procession to Oak Hill Cemetery; in addition, nearly a hundred people went by foot. James White was laid to rest in the family plot, where his two sons and his father and mother, John and Elizabeth White, were buried. ${ }^{2}$

Return to Everyday Life:

After the funeral Ellen White was taken back to the Sanitarium for the night. On Sunday she was taken on a bed out to their home, where she was joined by the members of the family who attended the funeral. ${ }^{3}$

In the White family's grief they observed some of the same rituals as the sons of Jacob.

1. The Death of John Herbert (three months old) - Personal Notification/Moment of Death; Family/Community Mourning; Burial; and Return to Everyday Life.

2. The Death of Henry Nichols (sixteen years old) - Background; Spiritual Preparation; Last Will and Testament; Life Review; Charge and Testimony; Submission to the Will of God; Moment of Death/Gathering Around the Bedside; Family/Community Mourning; Funeral; Fulfillment of Request; Burial/Internment; and Return to Everyday Life.

\footnotetext{
${ }^{1}$ Ibid., 174-176.

${ }^{2}$ Ibid., 176-177.

${ }^{3}$ Ibid., 177.
} 
3. The Death of James Springer (husband of 36 years) - Life Review, Confession, and Forgiveness; Personal Notification; Prayer Vigil by Faith Community; Family/Community Mourning; Funeral; Burial/Internment; and Return to Everyday Life.

What has been revealed from the White family history is that the personal and community rituals correspond to the biblical foundation in the Old Testament relative to the death and burial of Jacob.

From our study of Ellen G. White it is important to be proactive when it comes to preparing for death and to articulating our wishes. Today, family members should not have to second-guess whether or not organ donation is appropriate; it should be clearly known by the family what the deceased would have wanted. With the help of modern technology, we now have available to us many of the documents and procedures that can make life easier and less complicated for the bereaved - estate planning, the living willing, health care power of attorney, planning one's own funeral, and pre-burial arrangements (cremation or burial). All of these are love gifts that can provide assistance to the bereaved. They inform the bereaved of the person's wishes and requests and allow them to enter the grieving process with the assurance that they have honored the deceased. This can promote good grief.

This historic background lays the foundation for the development of a training program for Grief Ministry. Bereaved persons do not have to grieve alone. With the guidance of trained grief ministers many will reach out and embrace the hope - helping others and ourselves prepare for an eternity - that is so desperately needed in this day and age. "Blessed are those who mourn, for they shall be comforted" (Matt 5:4). We are to comfort one another. 


\section{CHAPTER IV}

\section{PROPOSED GRIEF PROGRAM FOR GRIEF FACILITATORS}

When a loved one dies, there is a need to grieve the loss of that person. This need may be immediate or delayed. It all depends on the relationship that existed before the death occurred and how the person died. The pain of death originates in the subconscious mind and will eventually surface to the conscious mind. It is at the conscious level that an individual realizes that they cannot deal with their grief alone.

A strength of Grief Ministry is the ability to heighten the bereaved person's awareness of the deceptions that can be employed in their struggle between denial and reality. There are some who tell us that we become immortal at death. Solomon made this comment relative to the dead, "The living know that they will die, but the dead know not anything; they have no more reward, and even the memory of them is lost. Their love and their hate and their envy have already perished; never again will they have any share in all that happens under the sun" (Eccl 9:5, 6).

From a spiritual perspective, Frank Phillips in his book, His Robe or Mine, gives an analogy that helps us understand the part the mind plays in the great controversy between Satan and Christ:

The human mind is the battleground for the most deadly conflict ever fought on this planet. Christ seeks to control our minds so that we might reach the highest fulfillment of the capabilities that He, Himself, built into that marvelous organ. Satan, on the other hand, seeks to retain control of that mind which is "enmity against God" (Romans 8:7). The human mind has been compared to a computer 
in which the memory bank is being programmed every waking moment by one of two sources: Christ or Satan. Like the computer, the mind's function depends upon the information it receives. Having analyzed the information, the mind then determines its decisions and subsequent course of action. ${ }^{\prime}$

Human beings know that all living things will die but have difficulty accepting it.

Therefore the mind needs to be re-programmed when a loved one dies because there is an emotional desire to resist change or to deny the reality of the event. The first verse in the Serenity Prayer can become a vital part of this adjustment. "God grant me the serenity to accept the things I cannot change, courage to change the things I can; and wisdom to know the difference."

\section{Purpose of the Program}

The program is basically designed to meet the wholistic aspects of an individual mind, body, spirit - in a timely manner. The purpose of the program is to provide tools that can be utilized to promote health and healing in those who are grieving. Over the past fifteen years many programs have been promoted as grief recovery programs that are most likely promoted and provided in the hospital environment. ${ }^{3}$ The challenge is to make use of the benefits of these programs outside of the hospital and in the Seventh-day Adventist Church. Recognizing the individuality of grief, it has become increasingly necessary to develop a program that is designed to minister to people in such a way that they can manage their own grief. The secret is to intentionally enter the grieving process and manage the pain constructively. By giving oneself permission to grieve, three

\footnotetext{
'Phillips, 12.

${ }^{2}$ Reinhold Niebuhr, 1934, http://open-mind.org/Serenity.htm, February 17, 2004.

${ }^{3}$ Grief Recovery: The Action Program for Moving Beyond Grief www.grief.net; AARP: www.aarp.org/families/grief-loss/a2004-11-15-remember.html; Funeral Planning: Everything You Need to Know About Funerals, Funeral Homes and Grief Support www.funeralplan.com, July 27, 2005.
} 
aspects of human experience are nurtured immediately - mental, emotional, and physical. The spiritual, which is the fourth aspect, needs to intentionally reach out to God. That power outside of self will be the sustaining power during these hours of bereavement.

The pilot program was held September 5-7, 2003, in the Theological Seminary at Andrews University, Berrien Springs, Michigan. The program consisted of eight hours of seminar activities and eight to twelve hours of reflection.

\section{Description of the Program}

The Grief Ministry Program for Facilitators consists of six seminar sessions (see Appendix K). These sessions are held for three days, preferably over a weekend - Friday evening, Saturday afternoon, and Sunday morning.

The pre-requisite for this program is to read chapters 23 through 27, regarding the Doctrine of Last Things (see Appendix H), in the book Seventh-day Adventists Believe: A Biblical Exposition of 27 Fundamental Doctrines. ${ }^{1}$ It is suggested that each participant sign a statement saying that they have read these chapters.

Due to the intensity of the program, each participant is encouraged to take the program seriously and recognize their need for commitment, attendance, and participation in all six sessions. Grief work is a process, and each seminar is a building block with a focus. Therefore a written agreement to attend all sessions would be appropriate at the beginning of the seminar.

This is a Christian-based program and each session begins with prayer, a song, and a review of the exercises from the previous session. Sharing of one's mental, physical, emotional, and spiritual reactions or responses to the take-home exercises,

\footnotetext{
${ }^{1}$ Seventh-day Adventist Ministerial. Association, 311-383.
} 
regardless of how small or insignificant they may seem to a participant, is helpful to all and beneficial for future programming.

The conclusion of the program is a Service of Remembrance with a Rose Bud Ceremony, which is a prelude to letting go of the physical relationship with the deceased.

\section{The Format of the Program}

SESSION ONE: LET'S GET ACQUAINTED (see Appendix K, Grief Ministry Training Manual). The objective is to allow the presenter and the participants to mingle and get acquainted with each other; to dispel the fear of entering the grieving process, offer a sense of confidence and support of those attending, and develop a safe and trusting environment. These factors will bring the group together by giving participants time to tell their grief story without probing or pressure. At the end of the session each person should be aware of his or her personal work involved in the grieving process and take responsibility for his or her own grief work.

Instructions are given relative to confidentiality, registration, and general housekeeping, rules and regulations. A song is used to bring participants into a center place. The session begins with prayer. At this time the presenter is introduced and the communication is kept in generalities about grief and the grieving process. Each participant is expected to complete a Self-Assessment on Life Events Scale ${ }^{1}$ and tally it during the session - preferably as a part of their registration.

It is important that the facilitators come face-to-face with the losses they have had in their own lives. The expectation is that they will discover that they are able to deal

\footnotetext{
${ }^{1}$ Holmes and Rahe, 213.
} 
with their own mortality. It is generally understood that it is helpful in ministering to others effectively if one first deals with one's own pain.

To accomplish this, each facilitator needs to enter the grieving process as a participant or as a sharer in the grief of fellow perspective facilitators. Experience becomes the best teacher. J. Jeffrey Means reminds us of the culture and time in which we live and how it affects our behavior and understanding of our environment.

We work within a culture that is preoccupied and driven by technology, speed, and objective, measurable, and knowledge-distance therapeutic objectives. Most people are still willing to be patiently waiting seven or eight months for the tulip bulbs planted in the fall to bloom in the spring, and would think it ridiculous if someone suggested the process could be speeded up by digging down into the ground and yanking the flower into the sunlight! At the same time, most of these same people, as well as their friends and employers, become impatient when complex and life long dynamic patterns within a human mind are not resolved in a month or two. Personal transformation takes time, nurture, hard work, and patience. ${ }^{1}$

The session ends with a take-home exercise that must be completed before the next session. This includes a Brain Freeze (a picture of a brain with lines and curves to aid participants in recording their losses) and Journal Writing (a sheet of paper or notebook with lines that will allow the writer to keep a straight line).

\section{SESSION TWO: EXPERIENCING GRIEF (see Appendix K, Grief Ministry}

Training Manual). Session Two begins with a welcome, a song, and a prayer. We want to acknowledge the presence of God in each meeting.

The objective of this session is for all participants to give themselves permission to grieve and seek the positive results of self-awareness relative to their "new normal" (a new life without their loved one). Time given for the participants to share their reaction and response to the completion of the exercises from Session One is paramount.

\footnotetext{
${ }^{1}$ Means, 46.
} 
Everyone must be given a chance to respond to the question, "What was it like for you to complete this exercise?"

Because of the emotional atmosphere that can be generated, the primary focus of this session is emotions-feeling words. There are several areas that we deal with and process: (1) External and internal feelings--Experiencing, (2) Adapting to loss-Grief Time Schedule, (3) Some problems in grief-A Look at Problems in Grief, and (4) Daily self-healing - Letting Go; Things to Do. This session concludes with an exercise that must be completed before the next session - Itsy Bitsy Criticism Committee (IBCC). Call this mental committee together for five minutes and then dismiss it until the next day at the same time; this will allow you to spend twenty-three hours and fifty-five minutes doing whatever makes you happy and conclude with the Serenity Prayer (if the committee tries to convene, remind yourself of the time for the meeting tomorrow and banish the thought).

\section{SESSION THREE: STAGES OF DEATH, STAGES OF GRIEF AND STRESS} MANAGEMENT (see Appendix K, Grief Ministry Training Manual). Session Three begins with a welcome, a song, and prayer. The objective is to bring about a level of comfort while not allowing the mind to play games or tricks. In this session we deal with the stages of grief and share practical ways to relieve stress and tension. The sharing of the completion of the exercises from Session Two is paramount. Their responses should be centered on the question, "In completing the IBCC, which aspect of your being was touched by this exercise - mind, body or spirit; and did you make another appointment with the committee?" 
There are Five Stages of Death (Grief) that were introduced by Elizabeth Kubler Ross in her book, On Death and Dying': Denial, Anger, Bargaining, Depression, and Acceptance.

There is also a book entitled Good Grief, written by Granger E. Westberg, that gives Ten Stages of Grief - Shock, Emotion, Depressed and Very Lonely, Physical Symptoms of Distress, Panicky, Sense of Guilt About the Loss, Anger and Resentment, Resist Returning, Hope, and Affirm Realty. ${ }^{2}$ Participants are guided in comparing their experience to these stages.

Stress management and relaxation are discussed and demonstrated in the program in an attempt to help participants understand the physical reactions to grief such as the tightness of the muscle and tension. We talk about the general factors that aid relaxation and relaxation routines.

This session concludes with two exercises: "Be Good to Yourself"' as suggested by Larry Yeagley in his book entitled Grief Recovery, and Practice Breath Prayer ${ }^{4}$ as a nightcap for a peaceful sleep. Prayer is the breath of life that counts.

SESSION FOUR: PEACE OF MIND, Part I: LONELINESS (see Appendix K, Grief Ministry Training Manual). Session Four begins with a welcome, a song, and prayer. The objective of this session is to begin getting in touch with oneself, accepting one's limitations, and drawing on one's strengths. It is necessary to deal with loneliness, and prepare for the holidays and other special times that were significant before the loved

\footnotetext{
${ }^{1}$ Kubler-Ross, 51-146.

${ }^{2}$ Westberg, 21-63.

${ }^{3}$ Yeagley, 61-63.

${ }^{4}$ DelBene, Montgomery, and Montgomery, 7-9.
} 
one died. The sharing of the completion of the exercises from Session Three is paramount. The questions are, "What did you do that was good for you last evening?" "Did you discover your Breath Prayer?"

Loneliness is not always the state of being alone; many people are in a crowd and they are still lonely. We look at six areas of loneliness: Nobody Cares, Chronic Loneliness, the State of Loneliness, Types of Loneliness, Snowflake, and You Are His/You Are Valuable.

We spend a lot of time dealing with loneliness. The source of this presentation comes from the book, Lonely No Longer, by Mark A. Finley. He says, "You will find that even loneliness can be enriching if it chases you to God, clears your heart, and lets your very best part shine through."1 This session concludes with an exercise, "God's Personalized Plan and Certainty of Christian Living."

SESSION FIVE: PEACE OF MIND, Part II: FIVE TOPICS FOR THE GRIEVER (Appendix K, Grief Ministry Training Manual). This session begins with a welcome, a song, and prayer. This is the most spiritual session. We focus on the presence of God.

The sharing of the completion of the exercises from the end of Session Four is paramount: God's Personalized Plan and Certainties of Christianity.

We spend time reassuring the participants of God's love and presence in their lives. We discuss five topics that make a tremendous difference in the lives of those who are grieving: You Are in Good Hands, Without Doubt, Forgiveness, Incredible Trade, and Breaking the Cycle of Loneliness.

\footnotetext{
${ }^{1}$ Finley, 80.
} 
This session concludes with a homework assignment, the biblical reading of Gen 11:27 - 25:11, the life of Abraham.

SESSION SIX: ABRAHAM A BIBLICAL ROLE MODEL (see Appendix K, Grief Ministry Training Manual). Session Six begins with a welcome, a song, and prayer. Hebrews 11:1-22 is used as an introduction to this session as a responsive reading. The sharing of the completion of the exercises from Session Five is paramount. We discuss the life of Abraham as he journeyed in the Promised Land and compare his life with our lives today.

This session concludes the seminar portion of the program and participants are asked to talk about the effect that this seminar has had on their lives and how they plan to utilize the information and experience they have had. Then we sing our theme song and repeat the Mizpah. The participants complete and turn in the evaluation of the program and say goodbye in words, embraces, etc.

There is also the option of conducting a Service of Remembrance that includes a Rose Bud Ceremony (See Appendix G). The purpose is to put finality on the whole event.

\section{The Participants of the Program}

It is suggested that the participants in this program be responsible adults who are seriously searching for a ministry to nurture members within the Seventh-day Adventist Church and have a burden to minister to those in the local community who have lost a loved one.

Once the training program is completed, the complete package has sufficient materials and exercises to develop and hold Grief Recovery Programs in several formats 
for a seven-week, one hour-per week or a weekend intensive. This program has evangelistic potential for people of all ages. 


\section{CHAPTER V}

\section{EVALUTION AND REFLECTIONS OF THE PROGRAM}

The implementation of the pilot program is to determine its viability and usefulness within the community of believers that will touch the heart of members who are searching for their call to ministry. Grief Ministry requires the leadership of an adult who has caught the vision of the need to minister to those who have lost a loved one and is familiar with the pain of grief. In order to minister to the needs of others a person must deal with their mortality and losses and have the gift of compassion.

There are many who are stuck in the grieving process and are seeking help in understanding how God fits into helping them resolve the pain. Many are yearning for counsel on how to be free from their pain and suffering. They turn to the church to provide words of comfort and support during this sensitive time when all hope is gone and they feel powerless, lonely, helpless, and have a strong desire to see their loved one again. In the time of grief their hope needs to be revived and strengthened. God has bestowed upon specific individuals a giftedness to build up their brothers and sisters in the faith that they may encourage one another.

\section{Program Presentation}

There were twelve in attendance: Six were from campus housing and six were from local communities. 


\section{Pre-Program Questionnaire}

The Grief Questionnaire (see Appendix B) was distributed to those in attendance during registration. For confidentiality the respondents were kept anonymous. Each questionnaire was given a number to facilitate statistics. By completing this Grief Questionnaire respondents were giving me permission to use the data as a part of my dissertation project.

There were nine areas on the questionnaire: (01) Marital Status, (02) Education, (03) Occupation, (04) Age, (05) Time Source of Loss (e.s.), (06) Number of Losses, (07) Categories of Losses, (08) Emotional Assessment, and (09) Physical Symptoms. See table 1.

As shown in table 1, there is a broad range in the marital status of the participants; the educational profiles are high; the occupations were based on the location of the seminar; and the age range covered the whole spectrum of adulthood.

Two items on the questionnaire were relative to time (see tables 2 and 3). This time involves the most recent death(s) and the number of death(s) during a given time frame.

Table 2 reveals that many of the participants may be dealing with some unresolved/accumulative grief issues because of multiple deaths in the same time period and in more than one time period. It is ideal that many of these losses would be processed. However, the confidentiality of the questionnaire requires that the expressed need be verbalized by the participants when they feel comfortable. There is always the possibility they may not address their needs during a Grief Ministry Seminar. 
Table 1. Demographics

\begin{tabular}{|c|c|}
\hline Demographic & Number \\
\hline \multicolumn{2}{|l|}{ Marital Status: } \\
\hline Married & 3 \\
\hline Single & 6 \\
\hline Divorced & 1 \\
\hline Widow & 1 \\
\hline Widower & 1 \\
\hline \multicolumn{2}{|l|}{ Education: } \\
\hline High School & 1 \\
\hline Undergraduate & 2 \\
\hline Graduate & 9 \\
\hline \multicolumn{2}{|l|}{ Occupation: } \\
\hline Seminary Students & 6 \\
\hline Retired & 2 \\
\hline Graduate Student & 4 \\
\hline \multicolumn{2}{|l|}{ Age: } \\
\hline $18-25$ & 3 \\
\hline $26-35$ & 1 \\
\hline $36-45$ & 3 \\
\hline $46-55$ & 1 \\
\hline $56-60$ & 2 \\
\hline $66+$ & 2 \\
\hline
\end{tabular}


Table 2. Time and Number of Deaths

\begin{tabular}{lc}
\hline Question & Number \\
\hline How long has it been since your last loved one died? \\
$0-6$ months & 3 \\
$7-12$ months & 3 \\
$1-2$ years & 3 \\
$3-5$ years & 0 \\
$6+$ years & 3 \\
& \\
\hline \multicolumn{2}{c}{ Give the number of deaths you have suffered during } \\
\multicolumn{2}{c}{ the time periods below. } \\
$0-6$ months \\
$7-12$ months \\
$1-2$ years \\
$3-5$ years \\
$6+$ years & 4 \\
& 4 \\
\end{tabular}

In some cases deaths of friends surfaced during the sharing not relating to the immediate kin death(s) that the person is cognizant of. This information had not been requested on the questionnaire but was processed. This historical data retrieval becomes what is referred to as a "mind melt-down" - a mind exercise in which persons give themselves permission to search out and retrieve death data stored in their memory banks. They are surprised by what surfaces to the conscious mind.

The next question on the questionnaire became the introduction to the grieving process. It allows participants to consciously consider categorizing their most current loss.

It is not always easy to categorize the death of a loved one. What is presented in table 3 should not be considered as the categories and examples of all deaths. It is an 
attempt to provide examples that will help the participants in acknowledging their understanding of death and aid in the grieving process.

Table 3. Current Loss

\begin{tabular}{lc}
\hline Question & Number \\
\hline How would you categorize your most current loss? & \\
& 4 \\
Normal Death (Old Age) & 1 \\
Expected Death (Terminal Illness) & 1 \\
Anticipated Death (Hospice) & 4 \\
Sudden Death (Heart Attack/Accident) & 2 \\
Not Sure & \\
\hline
\end{tabular}

These categories are not exhaustive and should not be considered as the only ones. Categories cannot lessen the pain relative to the death of a loved one. One participant added the category Still-Born/Loss of Fiancé. Probably Loss of Fiancé fits in one of these categories, but Still-Born is a category all its own and will be included in future questionnaires.

Let us take a brief look at the meanings behind the five categories in table 3 . A Normal Death is based on the presumption that we live, get old, and die. A physician has not diagnosed a terminal illness. An Expected Death is not just related to a terminal illness but any illness that includes a long period of waiting. The prognosis is that the illness will be the cause of death. Anticipated Death is related to a short-term terminal illness. Hospice care is generally placed in this category. Death is imminent, and the family has made pre-funeral arrangements. Sudden Death comes without expectation and 
generally happens by accident, heart attack, drowning, or any number of causes and it can be particularly traumatizing. Sometimes individuals have not thought of categorizing the death of a loved one and are not sure of the appropriate category.

Item 8 on the questionnaire dealt with six statements revolving around an Emotional Assessment (see table 4) on a scale of 1-5, ranging from Strongly Disagree to Strongly Agree. Again the goal is to encourage the participant to think about their emotional reaction or response to the death of their loved one.

Table 4 opens before us the mental awareness of each participant and says a lot about their mind-set relative to loss of a loved one.

Although most of the participants are suffering from some emotional trauma relative to the most current death of a loved one, the Bible plays a significant role in their lives as a source of hope and spiritual strength.

It was interesting to note that in response to the statement, "The Church/Faith Community has been supportive to me and my family," one participant did not respond at all. We consider it a privilege to know that for the majority of the participants, there appears to have been some support from the local church during the loss of a loved one and yet we don't know what kind of support was available, how much support, or the time period involved in their response to the loss. Also we didn't know whether the person was a recent or long-term member of the church, which may have an impact on the amount of support given to the family during the time of bereavement.

It was unanimous among the participants that God is not blamed for the death of their loved one. 
Table 4. Emotional Assessment

\begin{tabular}{|c|c|c|c|c|c|}
\hline Statement & $\begin{array}{l}\text { Strongly } \\
\text { Disagree }\end{array}$ & Disagree & $\begin{array}{c}\text { No } \\
\text { Opinion }\end{array}$ & Agree & $\begin{array}{l}\text { Strongly } \\
\text { Agree }\end{array}$ \\
\hline $\begin{array}{l}\text { This death has caused } \\
\text { emotional trauma in } \\
\text { my life. }\end{array}$ & 0 & 3 & 1 & 5 & 3 \\
\hline $\begin{array}{l}\text { The Bible has been a } \\
\text { spiritual resource } \\
\text { for me. }\end{array}$ & 0 & 0 & 3 & 2 & 7 \\
\hline $\begin{array}{l}\text { The Church/Faith } \\
\text { community has been } \\
\text { supportive to me and } \\
\text { my family. }\end{array}$ & 0 & 1 & 1 & 5 & 4 \\
\hline $\begin{array}{l}\text { I blame God for the } \\
\text { death of my loved one. }\end{array}$ & 8 & 4 & 0 & 0 & 0 \\
\hline $\begin{array}{l}\text { People say I need to } \\
\text { do something about } \\
\text { my grief. }\end{array}$ & 5 & 3 & 2 & 1 & 1 \\
\hline $\begin{array}{l}\text { I am willing to do } \\
\text { grief work. }\end{array}$ & 0 & 1 & 0 & 4 & 7 \\
\hline
\end{tabular}

The impact of grief relative to others may have several meanings. It seems that other people were not encouraging them to do something about their grief. They were expected to handle their own grief and not push their pain on others. People were afraid or hesitated to say something. They were obviously doing something about their grief.

The majority of the participants were willing to do their own grief work. This was very positive because it reflected that each person knew why they had come to the seminar and would do their best to work with the program. One of the participants had 
several deficits that we as a group worked with: he was mature, unable to read, and preferred one-on-one.

Item nine of the questionnaire (see table 5) addressed some of the physical symptoms one might experience after the death of a loved one. Here are the results relative to that statement.

Regarding the data in table 5, two of the participants experienced more than one of the above symptoms. This is not unusual when grieving or mourning the death of a loved one. An individual can experience all of the above symptoms and others over a period of time. One participant did not respond to the statement, and one participant included stress, an additional symptom.

Table 5. Physical Symptoms of My Grief

\begin{tabular}{lc}
\hline Physical Symptom & Number \\
\hline I have experienced the following physical \\
Symptoms of my grief. \\
\\
Sleep Patterns & 3 \\
Low Energy & 3 \\
Weight Gain/Loss & 4 \\
I Get Less Done & 2 \\
Other (Stress) & 3 \\
\end{tabular}

These questionnaires are a valuable tool when completed at the beginning of the seminar. It is highly recommended that the presenter review these questionnaires several times in a private environment. Becoming familiar with the statistical data will serve as an advantage, allowing the presenter to anticipate and prepare to address these situations and circumstances that may arise. The information and knowledge contained in the 
questionnaire also allow the presenter to personalize the seminar to meet the overall needs of the group. Although the material presented is standardized, the stories and examples can be adjusted to meet the holistic aspects of the participants - mind, body, spirit.

\section{Post-Program Evaluation by Participants}

One of the most powerful tools that a presenter receives in each and every seminar is feedback from the participants. An evaluation is the form used to gather information relative to the reactions of the participants to the seminar, the presentations, the materials, and the presenter. It also gives the participant the opportunity to express their opinions on various aspects of the seminar that can be helpful in preparation for future seminars. These documents are completed on a voluntary basis at the end of the seminar. The results must be considered as constructive criticism in order to allow for continued growth and development for future programs.

This evaluation in table 6 covers five major areas of concern: (1) Information about the seminar itself relative to location and time, (2) the materials that are distributed, (3) the biblical applications, (4) the presenter, and (5) comments and/or suggestions for future consideration. A five-point scale was used to weigh the results, with 1 being Poor and 5 being Excellent. Although there were twelve participants at the beginning of the seminar, only eight of them completed the evaluation, which totaled 67 percent. This in itself is good and appreciated anytime there is more than 50 percent. 
Based on the data in table 6 , the location and the days played a significant role in the success and reception of the seminar itself. This will be further discussed and analyzed in the comments and recommendations part of the evaluation report.

As an overview of the material distributed and utilized during the seminar, it appears that the majority of the participants received the material and felt it met the criteria for a Grief Ministry Seminar.

In applying grief and grief ministry to the two biblical role models - Abraham and Jesus - it is apparent that the participants felt that the exploration into the Old and New Testaments was resourceful to their understanding. The presentations received a very positive response from the participants who were very vocal in their comments and recommendations.

Respondents' response to three inquires are presented below. In response to the question about what respondents liked about the Seminar, these responses were given:

1. "Information, energy of the speaker."

2. "It addressed my personal needs."

3. "It addressed relevant issues."

4. "The handouts and assignments given were very helpful."

5. "It promoted healing and 1 believe that it helped me to be in a better place."

6. "The personality of the presenter and her experience and vulnerability. The materials and handouts."

7. "The timing - over the Sabbath hours." 
Table 6. Evaluation

Areas of Concern $\quad$ Poor Fair Good Good Excellent
A. Information About the Seminar*
Location
Friday Evening
Saturday Afternoon
Sunday Morning

$\begin{array}{lllll}1 & 1 & 1 & 2 & 3 \\ & & 2 & 4 & 2 \\ & 1 & 1 & 1 & 4 \\ & & & 5 & 3\end{array}$

B. Material Distribution**

Grief Handouts

Exercises

$\begin{array}{llll} & & 1 & 7 \\ 1 & & 2 & 5 \\ & 1 & 2 & 4\end{array}$

C. Biblical Presentation of Role Models***

Abraham

Jesus

$\begin{array}{lll}1 & & 6 \\ 1 & 1 & 6\end{array}$

D. Presentation****

$4 \quad 3$

* One participant did not attend the Saturday Afternoon sessions.

** One participant did not attend the presentation on Loneliness.

*** One participant did not attend the presentation on Abraham.

**** One participant did not respond to this inquiry.

Regarding what respondents did not like about the Seminar, these responses were given:

1. "Times."

2. "Maybe the part of being filmed. Privacy factor."

3. "More small group interaction needed."

4. "Problem finding the location." 
5. "More interaction needed."

6. "It should have been longer."

There are several recommendations given by the respondents for seminar improvement:

1. "More interaction with the materials and each person. Is there a way to assess whether progress was made over the weekend program?"

2. "I feel that the seminar was hidden off into the basement and should have been in a more open and readily accessible place."

3. "Video presentation. Power point presentation."

4. "Maybe a private location - but it was fine."

5. "Time and more planning."

Other Comments were also given by the respondents and will be taken under consideration relative to future seminars:

1. "My understanding is very poor. How I got through twelve grades - I don't know. Poor in spelling and reading."

2. "Presentation - lots of experiences (good)."

3. "Exercises - (need more)."

4. "Presenter - she did an excellent job with what she had to work with."

\section{Reflections}

Friday-September 5, 2003, 7:00 - 9:00 p.m.

This is the first evening of the seminar. When we arrived at Andrews Theological Seminary around 6:30 p.m., we found it locked down. After contacting Campus Safety, they informed us that they had no computer record of a program scheduled to be held at 
the Seminary. Immediately I contacted the Seminary Dean, John McVay, by phone and explained to him what had happened and requested that he give the approval for the Seminary to be opened for the Grief Seminar that was scheduled for specific hours the whole weekend (September 5-7, 2003). This was very embarrassing for me but there was nothing I could do to change this time glitch. What was so painful was that there were several people who had come and left because it took about 30-45 minutes for Campus Security to return and opened the Seminary doors, and Room N150. Once we got into the assigned room the next thing was to set up, get people registered, connect the laptop to the overhead, and begin the presentation. As fate would have it, everything went well except the laptop did not work with the screen and we were unable to do the PowerPoint presentations. This meant that every presentation would have to be done without modern technology and that the each session would have to be streamlined.

There were twelve participants who stayed by, in spite of this temporary setback and the time constraints, which were a clear indicator to me that they wanted to deal with their grief or were very curious about the seminar. We milled around in an informal way, introducing ourselves, and completing the appropriate forms--the Registration Form and the Self-Assessment on Life Events Scale (SALES). Some were hesitating to tabulate the SALES scores because it revealed the possible chances they may be at risk for a serious illness. This was personal information not shared during the seminar. I could tell from many facial expressions that their work was cut out for them and they were not happy with their scores. We did the general housekeeping relative to bathrooms, water, exits, and breaks. 
There were four people who came in weepy and expressed the need for emotional relief. One person in particular was silent and "very weepy." I think he used half of the box of Kleenex that was next to him in the first few hours we were together. Our song for the seminar was "I Come to the Garden Alone," which set the pace for the seminar. After the opening prayer we talked briefly about the instructions that a flight attendant shares with the passengers on a plane before it takes off, specifically as it relates to the oxygen mask. I shared with them that mind, body and spirit must work together to lessen the pain of grief. I explained to them the importance of the SALES scores and entertained any questions they might have at that point.

They responded to the questions, "What brought you to this grief seminar?" As they begin to share their reason for coming, I noticed that 'Very Weepy' was unable to speak without crying. We would pass him up to give him a little time to pull himself together and periodically tried to come back to him but with no avail.

Then I got the shock of life: My assistant became a participant after the first hour into the program. She had recently lost her parents exactly one year apart in August 2001 and 2002 and was dealing with this current grief. She later explained that she felt the need to be a participant because the pain of her loss was so overwhelming while listening to the others share their pain and she wanted to be healed. This left me to do basically everything without an assistant.

As we passed around the handouts that needed to be completed before our next session, there was this feeling of resistance toward the one exercise. The Brain Freeze is an exercise that challenges the participants to intentionally stop, take time out of their 
busy schedule, do a little reflection, and search their mind for all the losses, grief, and sorrow they have felt in the past year or more. This process is a "brain meltdown," where the participants give themselves permission to retrieve information from the subconscious mind and allow this information to surface to the conscious mind. Because the brain is releasing historical information, it is suggested that the participants journal their thoughts. Journaling is writing down on a piece of paper or in a notebook the information that is surfacing. It is a way of taking that which is inside and putting it on paper so that one can look at, analyze, and recapitulate the circumstance and events surrounding these significant losses. It may be that before an individual can deal with their current grief, they must first deal with a grief that they are not aware of, which may be blocking them from letting go of the current pain. This can be liberating and painful, but it is healthy and a vital part of the grieving process.

We had our closing prayer together and the participants began to leave. I shook hands at the door. As the four weepy participants left I encouraged them to complete the exercise and come back on Saturday afternoon with these words, "It will get better, hang in there. See you tomorrow afternoon." They each assured me that they would be at the next session.

\section{Saturday—September 6, 2003, 3 p.m. - 6:00 p.m.}

This was an afternoon meeting. I was a little concerned because this was after lunch and the fear was that participants would be too sleepy to stay on focus.

When we arrived at 2:45 p.m. the building was locked. As we waited for Security, several of us greeted each other in the parking lot; then they helped bring in the 
materials and the water. The immediate feeling I got was that the exercise had created a lot of thought and the experience had produced positive results. We came together as a group very quickly. Three of the participants seemed to be very anxious to get started. Our theme song sounded like a choir with all its different parts and really set the pace for this session. I had the opening prayer. When I looked into the faces of the participants I breathed a sigh of relief as we began. I welcomed everyone and led out with the introductory question: "What was it like for you to complete the exercise - Brain Freeze?" The first hour was spent debriefing and sharing. Each participant was given 35 minutes. One of the anxious participants immediately expressed the fear they felt at the beginning, extracting from their brain the grief(s) she had experienced and writing it down on paper. The Brain Freeze allowed her to be open to herself. She talked about the death of her father at the age of six and how she had not forgiven him for leaving her. With tears she proclaimed she would never have an opportunity to know him as a father like other children. She remembered being in childcare after school and watching her friends respond to their father(s) who would pick them up. She would fantasize about her father picking her up or claim a friend's dad as her own. She felt that her father's death put a burden on her mother as a single parent. She had to raise three children all by herself in poor neighborhoods. As a Christian her mother never remarried and did not develop a relationship with another man. She acknowledged her anger at him and the impact his death had on their family and her inability to understand relationships and how they are supposed to work when it comes to men. Her experience is based on what she sees in others, books and television. Although she knows what she doesn't want, there is 
always the fear that they will die or leave her alone to raise a family by herself just like her mother. This was one time I wished I had a timer instead of the overhead clock. As I thanked her for sharing, I realized that she was just getting started so I had to tactfully move to the next person.

Other participants took it upon themselves to affirm her for her bravery in sharing so deeply and praised her for her accomplishments as a young adult before they shared their thoughts or experience with the exercise. One of the first session weepers was unable to share and passed with short statements, "I am not ready." "I can't do it." "It is too painful." Só we went on until everyone who wanted to share was given the opportunity. Another participant stated that he had not done the assignment because he could not read well and his attention span was short. Then we took a five-minute break. During the break I realized that I had to immediately develop creative ways to present the material in order to reach him and keep him with the group.

After the break we came together with the chorus of our theme song and moved into the presentation, "Experiencing Grief." The discussion centered on the thought of a new normal and how this has played out in their lives. One participant talked about their multiple losses over a short period of time and having to travel long distances to the funerals. The concern that they had was centered on a feeling of guilt. They felt that the family had placed unrealistic expectations on them because they where the 'educated one.' When they did not attend one uncle's funeral, several family members gave them a good old-fashioned tongue-lashing. They felt that their life had changed because of the multiple deaths and the need to make some adjustments was necessary. She made 
reference to her SALE score which confirmed the dangers to her health. I thanked her for sharing and I used her discussion on anger as a springboard to talk about emotions.

From this point we talked about Emotions and facial expression. I asked the question, "Do you know what you look like when you are angry?" We began to experiment with a mirror and the different emotions on the Emotions Sheet and discussed the Feeling Words that can be used interchangeably. One participant talked about not being able to show his emotions on the outside and not being taken serious when he says or names an emotion he is feeling. Only a few of the participants knew what facial muscles were used for different emotions. So we began to play around with facial muscles for such emotions as happy, sad, angry, afraid, eager, etc. The challenging part of this exercise was that once an emotion was called, we had to hold the facial expression for one minute and slowly relax the facial muscles. It was suggested that there are three ways to know what you look like to others. They are (1) by mentally imprinting the expression in your mind, (2) to see it with your eyes (look in a mirror); and (3) feeling it with your hands. It is a good thing to let others see your feelings and to make sure your face and feelings are saying the same thing. A lot of the tensions in the room began to dissipate as we moved on to discuss Part 1: A Look at Problems in Grief - Anger, Guilt and Estrangement. The only one we had not touched on was estrangement, which manifests itself when friends begin avoiding the griever and they withdraw. Most of the participants were surprised when they found out that "withdrawn" has its own facial expression (last emotion). We took a five-minute break. As we milled around at the water jug, a couple of the participants, pastors, inquired about being transparent with their 
parishioners by showing their emotions. They had been encouraged by other pastors not to show their emotions. This posed a deep concern for me because my response was, "Is it a sin to show your humanness to those you serve? I feel that it is a good thing for people to see that you hurt, have trials, and tribulations; that there is love, joy, peace, and excitement in your life. I reminded them that many parishioners see pastors and their family as role models in this drama of life. Sometimes we are the 'Christian life' that they have to compare."

We convened with the others as they sang the chorus to our theme song. We talked about the Grief Time Schedule and read the poem, "Letting Go," responsively. This set the stage for Part II: A Look at Problems in Grief. One participant admitted to running from the pain of grief and talked about staying awake at night to keep from dreaming or having flashbacks, leaving the lights on all night long, playing the television and radio to keep them company while at home, and medicating herself to sleep. Another participant talked about the occupation of the deceased and the denial they found themselves in until they were forced to acknowledge that she was dead and was not gone on a business trip. This was very painful for them to articulate. I expressed my sorrow and affirmed their courage and asked if they were able to share with us the real meaning for the tears. They immediately pulled out their journal and read the previous night's entry. It was powerful and almost numbing to all of us. I thanked him for sharing. We then looked at the handout, Things To Do, and talked about forgiveness of self, the deceased, and others. 
In preparation for our next meeting, Sunday morning at 9:00 a.m., we distributed the Itsy Bitsy Criticism Committee Form (IBCC). This form was to be their homework. I explained that everyone has a committee in their head that wants to convene at anytime and anyplace to mentally beat you up and tell you negative things about yourself. This committee plays on your emotions and can paralyze you or cause you to malfunction at work, at a social gathering, at church, at home or at school. I asked for a show of hands of those who have had this experience, and ten out of twelve raised their hands and a few confessed that they have experienced this committee many times, even relative to the grief seminar. One participant talked about how his father's voice would play in his mind like a tape recorder telling him how bad he was and that he would never amount to anything. Here he was in college, having gone further than his siblings or relatives, thanks to God leading, and he still had those negative tapes playing in his mind at times when he least expected.

I talked about the need to be intentional in allowing this negative/criticism committee to convene and adjourn it. The secret is to intentionally set a five-minute meeting by the clock, adjourn it and set another five-minute meeting at the same time the next day. The power is, you will have twenty-three hours and fifty-five minutes to praise the Lord or do whatever you want to do. So when the criticism committee tries to convene at any time other than the appointed time, you can remind yourself that you will meet with the committee at the appointed time. I convene my criticism committee every morning at 5:00 and adjourn at 5:05. Over the years I have found that there are times when there is nothing to criticize during my five minutes, but I still call the meeting, 
adjourn the meeting, and set it for the next day. That means that I still have my twentythree hours and fifty-five minutes to praise the Lord or do whatever I want to do, criticism-free, Hallelujah!

There are two forms on the page, one for you to set your first meeting before going to bed and one to set your next meeting. I give you permission to copy this form and use it for the first two weeks until you have firmly set your appointment in your mind. It has been my experience that the body begins to make it a habit and will wake you up to take care of business. To support yourself in this, it is okay to pray before and may I suggest that you repeat the Serenity Prayer. We prayed the Serenity Prayer. Have a good night and I will see you tomorrow morning.

Sunday Morning-September 7, 2005, 9:00 a.m. - 12:00 p.m.

As we arrived at the Seminar at 8:45 a.m., I noticed that the cars of some of the participants were not there. Sunday mornings are always difficult for some people because they want to sleep in and I could understand that myself. So I whispered a prayer and waited for Security. When Security arrived so did one of the participants. We could not help noticing him because for the first time he parked in the parking lot by backing in. He hopped out of the truck and offered to take in the supplies. This was our very weepy participant. He was groomed and had a big smile on his face. This was like seeing a human metamorphosis after three days and my curiosity got the best of me. After we got inside and began setting up I asked the question, "What happened to you last night?" He began to talk about the relief he received and the good night's rest he had experienced for the first time in years. I was in shock because this was the first time he 
was able to dialogue without crying. He was just thanking God for sending him to the Seminar. His confession was that he really didn't want to come but felt compelled to and now he knows why. I asked if he would share his testimony with the others and he agreed.

There were only a few of us but we got started with our theme song and prayer. When I asked about the Itsy Bitsy Criticism Committee Meetings and asked how they went, one of the participants exclaimed, "I did it and it really worked. I felt like I had power, I was in control of my thoughts." Looking around the room others were nodding in agreement. While we waited for others to come, I went around the room to check in with each one. Surprisingly they all had made another appointment for the same time. "Weepy" said he called his committee as soon as he got home and will be meeting with his committee again tonight. He also inquired about how healthy it would be to call the committee several times a day. I appreciated the question and suggested that we stick to the five minutes once a day and shared that I felt that it was best to leave it as is because too much of a good thing can become dangerous. However, I did remind them that if they felt the need to change their meeting time they could do that. While in the discussion several others showed up and apologized for being late.

We started this session talking about the five stages that where introduced by Elisabeth Kubler-Ross-Denial, Anger, Bargaining, Depression, and Acceptance. Most of the participants were familiar with these stages and expressed their knowledge and understanding of each of them. Their concern was, "Does everyone experience these stages before they die?" I was then able to piggy-back on the fact that Kubler-Ross's 
patients were terminally ill and shared how she ministered to these patients preparing them for their imminent death by providing hope and assurance through their own spirituality. This discussion touched many of the participants because their loved ones died of a terminal illness and the emotional trauma they experienced was real.

I gently led the discussion to those of us who are left behind with the responsibility of picking up the pieces and moving on by introducing Granger E. Westberg's ten stages of grief-Shock, Emotion, Depressed and Very Lonely, Physical Symptoms of Distress, Panicky, Sense of Guilt About the Loss, Anger and Resentment, Resist Returning, Hope, and Affirm Reality. This was the time I wished I had the PowerPoint working so I reminded the group that we had covered several of these topics earlier in previous sessions and I wanted to focus on "loneliness." This was a hot topic because everyone could relate to it. Loneliness can be experienced even though they are married with children, in a crowd, vacationing, etc.; the feeling of loneliness just doesn't seem to go away. There are ways to deal with loneliness especially when we realized that we are not alone in our situation or circumstances. Our discussion centered around two types of loneliness: emotional isolations (abandonment after the loss of a relationship) and social isolation (lack of a social network). I talked about Mark Finley's book, Lonely No Longer, ${ }^{1}$ and the comfort I received by reading this short book. Mark dealt with six areas of loneliness and how God is there all the time: Nobody Cares, Stages of Loneliness, You Are One of a Kind, God's Personalized Plan, You Are in Good Hands, Without Doubt, Forgiveness, and Lonely No Longer. I even suggested that they

\footnotetext{
${ }^{1}$ Finley, 80.
} 
call "It Is Written" and order this free book (1-800-253-3000). We concluded with a short biblical exercise, “God's Personalized Plan and Certainty of Christian Livings."

We spent several minutes talking about the mental, emotional and physical stress that compounds after a loss and the need to take care of our minds, body and spirit, before taking our scheduled break. To aid in this and seeing that the majority of the participants seemed tired, we did some relaxation exercises - tightening and relaxing the muscles by forming a tight fist, counting to 10 beginning with 1001,1002 , and slowly relaxing the tension. We also closed our eyes and relaxed the muscles in the neck by dropping the chin to the chest with the same ten counts. This was followed by various other exercises. I suggested that they walk around the room during the break or walk to the bathroom and be back in five minutes.

After the break we spent a few minutes talking about ways to be good to oneself because when there is no one else, it is "me, myself and I." It seemed hard for some of the participants to grasp the need to be good to themselves without becoming conceited or selfish. So we shared ways that a person could make themselves happy, and each example came from a personal perspective: Go out to dinner, shopping, sports, flowers, music, movie, concert, visit friends, cooking, hobbies, travel, etc. I emphasized that no one should wait or expect someone else to make you happy or feel good about who you are. This would be an unrealistic expectation and can be a burden on someone else. It would be wonderful to have these thoughtful perks done by others, but don't hold your breath, it might not happen. If it does happen, celebrate with them and give thanks to God for their thoughtfulness. As a reminder I felt that there was no need to feel that a 
person needed to pay back someone for their kindness (I scratched your back only for you to scratch mine later) when it is done in love.

I introduced the concept of a daily breathing exercise, "Breathe Prayer." This concept was new to the participants so I begin to explain and demonstrate how it works. We all breathe automatically, mindlessly, and use only a part of our lungs. Breathe Prayer requires a specific exercise - intentionally expanding our rib cage, releasing our diaphragm, and filling our lungs with fresh air. After several times inhaling and exhaling, it is important for us to become mindful about what we are thinking and feeling. Then for every breath we inhale, think about God, and for every exhale, breathe out those negative emotions. Inhale (God is my Shepherd), exhale (I dispel my fear of darkness). Breathe Praying can be done anytime and anyplace. Paul tells us to "pray without ceasing" (1 Thess 5:17). This is a good exercise to begin this praying journey because we breathe without ceasing. This brief exercise brought joy and pleasure to most of the participants. Some did not want to stop. There were laughter and positive comments.

I noticed that we were racing against time and suggested to the group that we spend the remaining time to take a look at our biblical role model and explained why I felt that Abraham is the chosen one. We began our look with Heb 11:1-22. It was a joy to talk about Abraham's call and the one hundred years he spent in the Promised Land and how his relationship matured over the years. We talked about his imperfections and mistakes (Gen 11:27-25:11). The highlight came at the end of the discussion when one of the participants reminded us that God took an ordinary person with a willing heart and 
did extraordinary things through him, in his community and blessed him. This helped us to understand we are ordinary people who are willing to allow our God to take our lives and do extraordinary and incredible things in us and through us. Another participant talked about their journey to Andrews and how they felt this was God's leading. We had several students from other countries who spoke about their spiritual journey and how they could relate to being called and asked to leave family and homeland. One participant related to the abuse and persecution he felt in his homeland because of his Christianity, but had no regret for having made Jesus his choice. He spoke of his feelings of loneliness and trusting in God to make things right in His time.

Some of the participants were students who had to leave early, but those who remained talked openly about their future and how God was leading in their lives. We concluded with our theme song and repeated the Mizpeh.

They completed the seminar evaluations and we shook hands or hugged each other before separating.

\section{Evaluation by the Presenter}

The Grief Ministry Seminar held at the Theological Seminary at Andrews University was unique to many experiences I have had relative to presenting a grief seminar. The purpose of the seminar was to heighten the awareness of many of the seminarians - pastors and students - that grief is not something experienced only by the members of the local Seventh-day Adventist congregation and community. Grief is ever present with us because no one is exempt from this natural pain. That is the price we have to pay for love. We are not among the untouchables. 
As a chaplain of fifteen years, my heart has ached for many years because many Christians are dying without the assurance of salvation and fear of being lost even though they have been faithful to God most of their lives. There are many who are looking for role models in the Bible among the faithful few to solidify their struggles and sufferings in this life. They are disillusioned because they will not allow the Holy Spirit to assist them in seeing beyond the text and taking hold of the power of the resurrection.

The objective of the Seminar was to reveal to the participants the humanness of two role models from the Bible who could serve as examples - Abraham from the Old Testament, because with him began the actual involvement of God in community; and, Jesus in the New Testament who was "God with us." He is God who took on human form and dwelled with His creation and showed us the way to live through Him and be recipients of the gift of eternal life.

The fellowship and wisdom gained from this Seminar have set a precedent that will serve as a model for many grief seminars to come. The participants were supportive and provided information for the present and future grief counselors as we minister to the needs of those in the church and in the community, realizing that we all have the common denominator of grief.

There was health and healing among those who utilized the Seminar for their betterment. It started off slow, but the exercises made it come alive. Lives were changed (see reflections) and more insight was shared into the lives of the biblical patriarchs. It was evident that many of the participants will read the Bible for a deeper understanding of the lives of all biblical characters because flesh has been added to the bones. 


\section{CHAPTER VI}

\section{SUMMARY, CONCLUSIONS, AND RECOMMENDATIONS}

The final chapter of this dissertation presents the summary of the Grief Ministry Seminar, conclusions regarding the six sessions of the Seminar, and personal and professional recommendations. It also contains the implementation of the program from the perspective of leadership, facilitator and administrative levels.

\section{Summary}

A Pilot Grief Ministry Seminar was held on September 5-7, 2003, at the Theological Seminary at Andrews University in Berrien Springs, Michigan. There were six sessions in this Seminar. Twelve Seventh-day Adventists participated in this Seminar. A day-by-day description of the activities and exercises are presented in chapter 4 with details in Appendix K. The purpose of the pilot seminar was to equip participants to become grief recovery program facilitators for local Adventist churches and to conduct formative evaluation of the training procedures.

The scriptural interpretation of the state of the dead makes it important and almost compels the Seventh-day Adventist Church to minister to the needs of the local congregation and community. It also uniquely positions us to minister to others including agnostics or atheists. 
Often people who are grieving are very susceptible to being manipulated into making bad decisions. Sometimes a belief that ancestors are watching what they are doing is used by others to take advantage of them. The Seminar recognizes and provides both scriptural support and other processes to help reduce the likelihood of people making unwise decisions while they are grieving.

The biblical truth that the dead do not know anything and God does not burn people in hell forever is healing to the whole being - mind, body, emotions, and spirit. Another very important concept is that the Scripture is clear that the living do not receive communication about their lives from those loved ones who have died. The relief expressed by the bereaved is best for the Christian. It is also good for individuals from other religious persuasions, and is consistent with the beliefs of the agnostic and the atheist. It could actually help them move in the direction of considering that there may be a God and that this God does not torture people in hell forever. This eliminates one of the greatest impediments to healthy grieving. The bereaved can now move ahead with their life without wondering who's looking over their shoulder and how their deceased loved one views what they are doing. There is a sense of freedom.

William Glasser developed an approach to psychiatry called Reality Therapy that parallels the approaches to the dealing with the past and the future used by Abraham and admonished of Paul. Simply summarized it has three parts: (1) You cannot change the past, let us deal with it factually, (2) Putting it behind we need to be honest about the present and our current reality; and (3) To determine where to go in the future and develop step-by-step plans for doing this and moving ahead with life. This thematic approach is used throughout the Seminar. 
The strength of Abraham's belief in God helped his approach to life in this way. Setting events behind him, he was honest about his present circumstances and he sought God's guidance so that he could move ahead in a way that was consistent with what he believed God wanted for him.

Paul in Phil 3:12-14 is very clear about putting the past behind because we can't change it and having a clear understanding of where we want to go and focusing on getting there. Establishing healthy goals and objectives for the future and acting in accordance with these is the most important outcome of the grief recovery process.

A study of the Scripture revealed eight points that facilitate healthy grieving: (1) Last Request and Instructions; (2) Personal Notification; (3) Family Charge and Blessing; (4) Moment of Death/Mourning; (5) Preparation of the Body; (6) Funeral/Community Mourning; (7) Fulfillment of Request/Burial; and (8) Return to Everyday Life (see Appendix C). Many of these concepts are similar to ideas found in the literature and in various cultures. When the community and the family follow procedures that honor the life of the deceased, it helps to facilitate the grieving process.

From this input a number of important conclusions and related recommendations were developed.

\section{Conclusions and Recommendations}

I would like to propose the following conclusions and recommendations as a synthesis resulting from information gathered from this pilot program. They are based on the presentations, observations, and discussions with participants. The Seminar met its goal. It provided a model that can and will be improved upon. For this purpose I am 
recommending ways for improvement, growth, and development. Many of them can be implemented now and others in the future.

Conclusion 1: In looking back over the Grief Ministry Seminar, I made the mistake of not providing the participants the opportunity to symbolically experience grief resolution. To add the Service of Remembrance and Rose Bud Ceremony as an additional session to the Seminar will allow participants to let go and say goodbye to their loved one in a tangible way.

Recommendation 1: It is recommended that one additional session be added to the Grief Ministry Seminar specifically to conduct the Service of Remembrance and Rose Bud Ceremony (see Appendix G).

Conclusion 2: The facilitator may not feel he or she has all the gifts and talents to effectively present a particular session of the Seminar. By developing a local community resource guide, they will be able to draw from within the congregation and the community those whom God has endowed with the gifts needed for this ministry.

Recommendation 2: It is recommended that provisions be made to incorporate, whenever necessary, other professionals in the areas of the six sessions of the Seminar to bring additional authority and versatility to the presentations.

Conclusion 3: In discussions with some participants it was suggested that consideration be given to grief ministry for children, teenagers and senior citizens. Their grief needs differ and they must be addressed and processed in an appropriate way. Children's grief is based on their lack of understanding about dying and death. Teenage grief has its sensitivity in relationships. Senior citizens must have an opportunity to enter 
the grieving process without being stereotyped because of their age (they have been through so much grief, they don't need to enter the grieving process).

Recommendation 3: It is recommended that modules be developed to meet the needs of specific age groups - children, teenagers, and senior citizens. Because of the number of individuals attending a grief recovery program, it may warrant a separate program or a module that could be offered for these specialized participants.

Conclusion 4: The Bible is full of grief narratives that are also appropriate as biblical grief role models. Some facilitators may feel more comfortable with a choice of biblical characters. Each biblical narrative can reach different individuals and people groups.

Recommendation 4: It is recommended that additional biblical role models be developed to provide choices for the spiritual aspect of the Seminar.

Conclusion 5: Promotional materials and processes need to provide the grief facilitator advanced knowledge about the numbers and types of participants. This will allow the facilitator to make program adjustments so that the Seminar will better fit the local needs of the congregation and community. Because the numbers and types of individuals with grief recovery needs will vary, a grief recovery program may need to be planned for one individual or very small groups of two or three.

Recommendation 5: It is recommended that a variety of promotional materials be developed for distribution to the local church or community before instituting a grief recovery program in the area. The promotional materials must include demographic survey information about potential participants. This is so that the facilitator can make appropriate program decisions, which may include working with individuals on a one-to- 
one basis, in a small group program, or make other important adjustments to the large group seminar.

Conclusion 6: Because this is a Seventh-day Adventist training program, it is necessary for all facilitators to have views consistent with SDA beliefs. We cannot take for granted that everyone has embraced all the doctrines of the Seventh-day Adventist Church.

Recommendation 6: It is recommended that an Adventist who is in training to become a facilitator read the last five chapters of Seventh-day Adventists Believe . . A Biblical Exposition of 27 Fundamental Doctrines, answer the questions provided for each chapter, and sign a contractual agreement (see Appendix H).

Conclusion 7: Lay members need to be encouraged to take an active and continuing role in Grief Ministry. This is most likely to happen if the pastor catches the vision of this undervalued and underdeveloped ministry. Pastoral support encourages lay members with the needed spiritual gifts to take the responsibility of establishing a grief program. By building support and cooperation among the local church leadership, the congregation will view this as a way of comforting those who mourn individually or in a grief recovery program.

Recommendation 7: It is recommended that the pastor encourage, support and provide coaching that will inspire lay members with appropriate spiritual gifts to lead out in grief recovery programs on a continuing basis. Making the grief ministry primarily lay-member conducted will help provide continuity and give lay members community service opportunities. 
Conclusion 8: There needs to be more than one approach to enable lay members with different spiritual gifts to become facilitators while making certain each approach has quality assurance.

Recommendation 8: It is recommended that in addition to the approach where individuals participate in a Grief Ministry Seminar while learning how to run a grief recovery program that additional approaches be considered. Two other approaches are: (1) To identify individuals who have taken a grief seminar and who have themselves conducted such programs and (2) Identify potential facilitators who are willing to assist a seasoned facilitator in conducting a seminar, and then have them lead out in seminars while being coached by seasoned facilitators. Every approach should grant a certificate to trainees upon completing predetermined quality-control expectations (see Appendix I).

Conclusion 9: There are many people in the community who can benefit by attending a Seventh-day Adventist Grief Recovery Program. When this ministry is shared with the community as an outreach program, a facilitator must have knowledge of other's religious beliefs. Other denominations' spiritual orientations, concepts on death, heaven, hell, and eternity should be well understood. This may require additional training on the part of the facilitator (see Appendix J).

Recommendation 9: It is recommended that facilitators have available a oneon-one non-Seventh-day Adventist module with spiritual sensitivity to other denominational beliefs regarding death and life after death.

Conclusion 10: The North American Division of Seventh-day Adventists already has many programs in place that could include Grief Ministry. By becoming culturally sensitive, we contextualize bereavement issues of all people groups. This ministry can 
become a connecting link to evangelistic efforts to draw many to Christ. Internet access and bi-monthly newsletters will keep all facilitators and other interested personnel up-todate on grief issues and concerns.

Recommendation 10: It is recommended that the North American Division lead out in Grief Ministry to the world church of Seventh-day Adventists.

Conclusion 11: The Hospice Foundation of America provides an annual teleconference relative to national grief concerns that can serve as a model for our own teleconference. This media effort can become a source of information, training, and continuing education for healthcare professionals (see Appendix K).

Recommendation 11: It is recommended that Grief Ministry Leadership of the North American Division sponsor a North American Division Annual Grief Teleconference offering Continuing Education Units.

Conclusion 12: There are nine Unions in the North American Division. Each union could sponsor an annual Union Conference weekend training seminar for its Conference's Grief Ministry facilitators. These seminars can be included as a part of the Family Life Programs, camp meetings, workers meetings, etc.

Recommendation 12: It is recommended that the North American Division Unions incorporate Grief Ministry as a part of their annual Union meetings to provide continuous support and outreach to their constituents.

Conclusion 13: There are recognized independent ministries within the Seventhday Adventist Church that can use Grief Ministry as a part of their outreach.

Recommendation 13: It is recommended that Grief Ministry training be offered by special invitation to recognized independent ministry organizations. 
Conclusion 14: One observation is that caring people who are going to die prepare family members for their demise. Preventive measures are of just as much value as the pathology. This procedure helps to facilitate good grief after the person has died.

Recommendation 14: Sermons by the pastor on preparing for death in spiritual and practical ways can help loved ones have a healthy grief experience. Informative workshops on how to prepare one's affairs before death will prevent grieving loved ones from having to make these decisions after the death. This will allow them to enter the grieving process with the thought of having fulfilled the wishes of the deceased.

Conclusion 15: Information was verbally given to the facilitators that would be more helpful if it would be in written form. This will help them understand how to implement the materials in a way that would best meet the needs of the participants. It will also help maintain the ongoing quality of the process. A guide to the facilitator's manual should be developed.

Recommendation 15: A Facilitator's Guide should be prepared. It would include specific instructions for each assignment and activity. It would have specific objectives, instructions, and background information for each session including each activity and assignment.

As I move ahead, the above conclusions and recommendations will be systematically implemented and evaluated in an effort to refine the ministry. One of the first objectives is to develop a Facilitator's Guide to the Facilitator's Manual. From the experience and suggestions of the participants, the Seminar demonstrated the need for Grief Ministry in the Adventist Church. 
APPENDIX 
APPENDIX A

DEATH OF A LOVED ONE 


\section{DEATH OF A LOVED ONE \\ GRIEF DEFINITIONS \\ by Joyce M. Hatchett}

\section{ANTICIPATORY}

$\begin{array}{ll}\text { DEATH / } & \begin{array}{l}\text { Grief } \\ \text { Bereavement } \\ \text { Grieve } \\ \text { Mourning }\end{array} \\ & \text { DEATH / } \\ & \begin{array}{l}\text { Grief } \\ \text { Bereavement } \\ \text { Grieve } \\ \text { Mourning }\end{array}\end{array}$

\section{/ ACUTE}

Grieving $>$ Resolution $>$ Good Grief

Process of Grief

/ ACUTE / CHRONIC

Cumulative/Unresolved

Grieve

Mourning

\section{Anticipatory Grief}

Is an experience of grief that occurs prior to the death of loved one and emanates from the expectation of emotional pain and the life changes the loss will bring.

\section{Death}

Is similar to the state of unconscious sleep but also includes the cessation of life.

\section{Bereavement}

Is the sorrow one experiences when a loved one dies.

\section{Grief/Grieving}

Is the emotional expression of deep sadness, as caused by bereavement - sorrow. Cry out!

\section{Mourning}

Is the time when people voluntarily come together on a small scale, publicly, privately, or personally, as a way of seeking closure of a relationship with the decease and/or support the family.

\section{Acute Grief}

Is the intense pain and confusion that occurs immediately after the death of a loved one.

\section{Grieving Process}

Are the responses of the mind, body, and spirit to the loss of a loved, voluntarily or involuntarily, depending on the choices made by the individual during the early states of grief.

\section{Resolution of Grief}

Is accepting the reality of the loss both cognitively and emotionally by intentionally reorganizing the many facets of one's life to accommodate the absence of the deceased.

\section{Good Grief}

Is kind of an oxymoron that presents the concept that grief is painful but if confronted and dealt with constructively it has good results.

\section{Chronic Grief}

Occurs after the death of a loved one and carries the same symptoms as acute grief but over a much longer period of time.

\section{Cumulative Grief}

Is when a person experiences several losses so close together that there is no time to recover from one loss before the next one occurs.

\section{Unresolved Grief}

Is grief that has not been dealt with. 
APPENDIX B

DEFINITION OF BIBLICAL TERMS 


\section{BIBILICAL DEFINITIONS}

by Joyce $M$. Hatchett

Below is a brief discussion of specific terminology that will come up in the course of Grief Ministry Seminar that warrant attention.

\section{Death}

Today death is one of the most misunderstood and sensational subjects on our planet. For millennia, death's true meaning has always been obscure and evokes feelings of fear, uncertainty, and mystery.

Because of its illusiveness, people turn to religious leaders for wisdom, knowledge, and understanding. Most world religions teach one of two schools of thought. Many people find it difficult to accept many of their teachings because they creates more questions than one dare to discuss or attempt to answer without a clear biblical explanation.

1) When a loved one dies the soul is not really dead but alive in purgatory to undergo purification, so as to receive the holiness necessary to enter the joy of heaven. After purification the righteous soul goes straight to heaven. Those who die in mortal sin immediately after death descend into hell to suffer the punishment of hell, eternal fire. ${ }^{1}$

2) Reincarnation beliefs come in many forms. For the Western and more sophisticated Eastern believers human beings always inhabit human bodies, however, it

\footnotetext{
${ }^{1}$ Joseph Cardinal Ratzinger, Catechism of the Catholic Church Second Edition , (Washington, DC: United States Catholic Conference, 1994), 266-276.
} 
has also been a widely held belief that the body into which a person migrates to can be that of an animal, a plant, or even an inanimate object. ${ }^{1}$

The Bible teaches that when a person dies the spirit returns to God who gave it at creation (Gen 2:7) and the body returns to the earth as it was (Gen 2:6; Eccl 12:7) whether they were righteous or wicked.

\title{
The Spirit
}

The spirit is the breath of life that Jesus breathes into the nostrils of man and woman and they became living souls (Gen 2:7, Job 27:3).

\section{Mortal}

To be mortal means subject to death. Humankind is mortal (Job 4:17), will die. All souls are subject to death (Roman 5:12). Therefore the concept that humankind as undying, immortal goes against the biblical teachings.

\section{Immortal}

To be immortal means not subject to death. Only God is immortal (1 Tim 1:17; $6: 15,16)$.

\begin{abstract}
A Soul
A soul is a living being, a combination of body (dust) plus breath (spirit). When a person dies, they are no long a soul. After death the person returns to the dust (Ps 104:29); know nothing (Eccl 9:5); possesses no mental power (Ps 146:4); has nothing to do with anything on earth (Eccl 9:6); does not live (2 Kings 20:1); wait in the grave (Job 17:13); and, continues not (Job 14:1, 2). 12.

${ }^{1}$ Paul Edwards, Reincarnation a Critical Examination, (Amherst, NY: Prometheus Books, 1996),
\end{abstract}


The distorted concept of death was instituted by Satan in the Garden of Eden when he said, "You shall not sure die" (Gen 3:4; Rev 12:9). This lie became one of the cornerstones of the devil's kingdom. This great deception has brought into the world spiritualism, a belief that supernatural agents receive power and wisdom from the spirits of the dead. ${ }^{1}$ Those who believe that the dead are alive become easy targets for the devil's deceptions. This behavior is Satan and his angels posing as loved ones who are now dead (2 Cor 11:13).

The Bible is the only resource that keeps the believer from being deceived by these incredible miracles (Matt 24:24; Rev 16:14). God's people will know from their earnest study of the Bible that the dead are really dead, not alive. Spirits of the dead do not exist. Therefore, God's people, the elect, will reject all miracle workers and teachers who claim to receive special "light" or work miracles by contacting the spirits of the dead (Acts 17:11; Isa 8:30). God's people will also reject all teachings that claim the dead are alive in any form, anywhere (Lev 20:27).

\section{Heaven}

Heaven as proclaimed by Jesus Himself is above (John 3:13). This is where the throne of God resides (Isa 14:12-15). The prophet Ezekiel saw this awesome throne in a vision and proclaimed it to us that we might believe (Eze 1:3-28). Even Jacob at Bethel was shown in a dream the angelic ministry of God on behalf of His people (Gen 28:12). The faithful died without having receiving the promise and are waiting in their graves for the Second Coming of Jesus Christ (Heb 12: 1,2). This waiting is confirmed by Paul as he gives us the assurance and reassurance of the power of the first resurrection (1 Thess

\footnotetext{
${ }^{1}$ Don F. Neufeld, Seventh-day Adventist Encyclopedia M-Z Second Revised Edition, (Hagerstown, MD: Review and Herald Association, 1996), 693-695.
} 
4:13-18). The Apostle John in the book of Revelation makes this profound proclamation, "Blessed and holy is he who has part in the first resurrection. Over such the second death has no power, but they shall be priests of god and of Christ, and shall reign with Him a thousand years," in heaven ( $\operatorname{Rev} 20: 6)$. It is after that thousand years that all things will be made new and the kingdom of our God and our Lord Jesus Christ will be set up on planet Earth and together we shall live forever and ever $(\operatorname{Rev} 21: 1-22: 5)$.

\section{Hell}

Hell is on earth and will be around the New Jerusalem after the wicked dead are raised at the end of the thousand years, this is the second resurrection. Satan is loosed from his prison and will attempt to rally the nations together to take the Holy City (Rev 20:7-9). Then the books will be opened and they where judged (Rev 20:11-13). The beast, the false prophet, the devil, Death and Hades, and anyone not found written in the Book of Life will be cast into the lake of fire ( $\operatorname{Rev} 20: 10,14,15)$. This is the second death. They shall be as stubble that burn up (Isa 47:14) and become ashes under the sole of the righteous feet (Mal 4:1-3). Sin and sinner will be forever destroyed, annihilated.

\section{New Heavens and New Earth}

God will create new heavens and a new earth (Isa 65:17, Rev 21:5), the home of the righteous (2 Pet 3:13). The tabernacle of God is with men. He will live with them. They shall be His people. God himself shall be with them and be their God (Rev 21:3). 
APPENDIX C

A HEALTHY GRIEF PROCESS CHART 
A HEALTHY GRIEF PROCESS CHART

by Joyce M. Hatchett

\begin{tabular}{|c|c|c|}
\hline ACTIVITY & DESCRIPTION & SCRIPTURE \\
\hline Last Request and Instructions & $\begin{array}{l}\text { Refer to their Last Will and } \\
\text { Testament which can be a Verbal } \\
\text { or Written Will given personally, } \\
\text { shortly before the actual death. } \\
\text { This may include instructions } \\
\text { about the disposition of their } \\
\text { body. }\end{array}$ & Jacob-Genesis 47:29-31 \\
\hline Personal Notification & $\begin{array}{l}\text { In most cases when the family } \\
\text { sense that death is imminent, } \\
\text { they begin notify family member } \\
\text { to come without delay to see } \\
\text { their loved one while they are } \\
\text { alive. }\end{array}$ & $\begin{array}{l}\text { Sarah-Genesis 23:3 } \\
\text { Joseph-Genesis } 37: 30-32 \\
\text { Jacob-Genesis } 48: 1-22 \\
\text { Lazarus-John 11:3-16 }\end{array}$ \\
\hline Family Charge and Blessing & $\begin{array}{l}\text { This is done at the bedside when } \\
\text { family members are gathered } \\
\text { around. Many times the dying } \\
\text { person speaks in a prophetic } \\
\text { voice to the living. }\end{array}$ & Jacob-Genesis 49:1-33 \\
\hline Moment of Death/Mourning & $\begin{array}{l}\text { This is the family's immediate } \\
\text { reaction to the death or last } \\
\text { breath of the loved one. }\end{array}$ & $\begin{array}{l}\text { Sarah-Genesis } 23: 3 \\
\text { Joseph-Genesis } 37: 33-35 ; \\
\text { 42:36-38; } 43: 3-11 \\
\text { Jacob-Genesis } 50: 1 \\
\end{array}$ \\
\hline Preparation of the Body & $\begin{array}{l}\text { Includes washing and/or } \\
\text { embalming. Wrapping or } \\
\text { clothing the body. Laying them } \\
\text { out on a couch or in a casket. }\end{array}$ & $\begin{array}{l}\text { Sarah-Genesis 23:19 } \\
\text { Jacob-Genesis 50:2 }\end{array}$ \\
\hline Funeral/Community Mourning & $\begin{array}{l}\text { The community comes together } \\
\text { to give their condolences and to } \\
\text { support the family during this } \\
\text { time of bereavement. }\end{array}$ & $\begin{array}{l}\text { Sarah-Genesis } 23: 33-35 \\
\text { Jacob-Genesis } 50: 3-4 ; 9-11 \\
\text { Lazarus John } 11: 17-33\end{array}$ \\
\hline Fulfillment of Request/Burial & $\begin{array}{l}\text { To complete the final wishes of } \\
\text { the decease as a way of honoring } \\
\text { their last written or articulated } \\
\text { request. The disposition of the } \\
\text { body. }\end{array}$ & $\begin{array}{l}\text { Sarah-Genesis } 23: 7-9,17-20 \\
\text { Jacob-Genesis } 50: 5-8 ; 12,13 \\
\text { Lazarus-John } 11: 34-43\end{array}$ \\
\hline $\begin{array}{l}\text { Return to Everyday Life } \\
\text { (Post funeral grief and extended } \\
\text { grieving process.) }\end{array}$ & $\begin{array}{l}\text { After the internment the living, } \\
\text { return to their homes and pick-up } \\
\text { their lives where they left off. }\end{array}$ & $\begin{array}{l}\text { Abraham-Genesis 24-25:6 } \\
\text { Jacob's Sons Genesis 50:14- } \\
21 \\
\text { Lazarus-John 11:44-46 }\end{array}$ \\
\hline
\end{tabular}

Even though they are not explicitly stated in Scripture, these practices are variously common to most grief and bereavement customs.

\section{A:/A Healthy Grief Process}


APPENDIX D

DR. J. H. KELLOG'S ACCOUNT

OF THE DEATH OF JAMES S. WHITE 


\section{Dr. J. H. Kellogg's Account of the Death of James S. White}

Arthur L. White, Ellen G. White the Lonely Years 1876-1891, Vol 3, (Washington, DC: Review and Herald Publishing Association, 1984), 170.

Dr. J. H. Kellogg, who attended James White through this week, gave an account of the case in the Adventist Review and Herald: I first learned of the illness of Brother White about 4:00 p.m., Tuesday, August 2, when I received a message from him requesting me to visit him at his residence, which I immediately did. I found him suffering with a very high fever, the pulse being 112 , and the temperature $103 \frac{3 / 4}{4}$ degree F. I learned about 10:00 a.m. of the same day he had suffered with a very severe congestive chill. At this time his head was greatly congested, and he complained of severe pain in the spine, extending into the lower limbs. He seemed to be greatly prostrated, and was very restless. Treatment to relieve the fever and pain was immediately ordered, and administered by a bath attendant from the Sanitarium. After a short time copious perspiration appeared, and he was greatly relieved. At 8:00 p.m. I saw him again, and found his pulse diminished to 96 , and his temperature to 101 degrees $\mathrm{F}$. At 11:30 p.m. his fever had entirely subsided. The case seemed to follow the rather familiar course of malarial fever, with elevated temperature in the afternoons. On Wednesday evening he was taken to the Sanitarium for treatment, accompanied by his wife. About noon on Thursday he began to show symptoms of fever again ... The pulse was rather weak, however, and in the evening, after the fever had subsided, became for a short time very rapid. He slept well through the night, however, and in the morning stated that he felt much better, though weak. He ate a light breakfast with relish, and expressed himself as feeling very comfortable and wholly free from pain during the forenoon, but took no dinner. There was some fever on Friday afternoon, and he was inclined to doze much of the time. Dr. Kellogg called as a consultant a Dr. Millspaugh, 
one of the Battle Creek's leading physicians. He was in full agreement with the diagnosis and favored the treatment administered. Friday evening some friends called, but talked only a little, as James White was inclined to sleep. His pulse was slightly irregular. Dr. Kellogg administered "strong stimulants," and Ellen White and a number of special friends were advised that his condition was critical. Kellogg continued: The grave symptoms grew rapidly worse for an hour, notwithstanding the most vigorous means of every sort, which were ready at hand. The pulse became exceedingly rapid, reaching 160 , and was very feeble and extremely irregular. The respiration was short and labored. The pupils were dilated almost to the extreme limit. Still the body was warm, and there was no evidence of chilliness, but the tendency to collapse from failure of the heart seemed irresistible. Consciousness was not entirely suspended, as he was able to answer any brief question intelligently. In the morning hours of the Sabbath he improved slightly. After some sleep he took a little fluid nourishment and improved for several hours. Thus it was till a little past the noon hour. Dr. Kellogg reported on the events of the afternoon: About 1:00 p.m. his pulse suddenly began to increase in frequency, and soon became very feeble and irregular. Within thirty minutes he became unconscious, and his pulse rapidly rose to 176 , and his respiration to 60 beats per minute. His temperature was 99 degrees F., one-half degree above the normal temperature. The same measures used with the previous attack were again employed, but without effect, and he remained in the condition described until he breathed his last, just after 5:00 p.m... . the severe shocks of apoplexy which he had suffered during the later portion of his life had so seriously impaired certain portions of the brain as to render him unusually susceptible to the malarious poison to which he had been exposed a short time before his death. 
APPENDIX E

REWARD AND PUNISHMENT AFTER DEATH 


\section{REWARD AND PUNISHMENT AFTER DEATH}

By Joyce M. Hatchett

This addition to the Appendix in Grief Ministry addresses a concern of the bereaved about the teaching on eternal burning fire. Some participants may think their loved one, after death, is being tortured in the fires of hell throughout eternity because of their sins. This is a painful thought. Misunderstanding the Biblical view of hell and hellfire can cause a negative and distorted view of God. An understanding of the Biblical view can provide comfort to the bereaved and promote grief recovery. This is only a summary of the subject, not an exhaustive study.

Eternal burning fire is a popular teaching in our world today which plagues Christianity. This concept teaches that those who die unsaved will burn in the flames of hell through all eternity. Eternal burning hell is referred to as 'hellfire', the punishment of the wicked. It implies eternal punishment of the wicked. To support this erroneous teaching, hellfire advocates have taken biblical passages related to hell and the wicked to formulate their teaching. These texts have been used inappropriately.

The word "hell" as used in the King James Vision of the Bible does not always mean a place of burning or punishment. The word "hell" is used 54 times in the Bible, and in only 12 cases does it refer to "a place of burning." In the Old Testament hell is translated 31 times from "Sheol", which means "the grave." In the New Testament "hell" is translated 23 times from three words: 1) Hades, 10 times which means "the grave", 2) Gehenna, 12 times which means "the place of burning"; and, 3) Tartarus, 1 time which means "a place of darkness".

\footnotetext{
'Amazing Facts Study Guide 11, Is the Devil in Charge of Hell? (Roseville, CA: Amazing Facts, 1994), 11-13.
} 
The 12 texts involving Gehenna, 'place of burning', are used as the primary support for the eternal 'hellfire' teaching. The use of Gehenna in the New Testament are organized into three sections based on the following New Testament texts: Section 1: Lake of Fire - is the second death when fire rains down from God out of heaven and annihilates the wicked. ( $\operatorname{Rev} 19: 20$, the 'lake of fire' burns with brimstone [sulfur]; Rev $20: 10$, It is a place of torment 'day and night forever'; Rev 20:14, going there is the 'second death'; Rev 20:15, anyone whose name is not written in the Book of Life goes there; Rev 21:8, those who are committed to sinning and not to Christ go there, including the cowardly and unbelieving; and, James 3:6, the whole body set on fire by hell.) Section 2: Eternal Fire - means fire with everlasting results, not an endless process. ${ }^{1}$ (Matt 18:8, hand, foot, eye cast in 'everlasting/hell fire; Matt 25:41, everlasting fire prepared for the devil and his angels (demons); and, Jude 1:7, the vengeance of 'eternal fire'.) Section 3: Unquenchable Fire - that hellfire will bring the wicked to destruction and ashes. Howard Peth says, "The fire which destroys the wicked must of necessity be unquenchable, for if it were not, the wicked would put it out."2 (Matt 3:12, burn up the chaff with 'unquenchable fire'; Mark 9: 43, 46, 48, the fire that shall never be quenched; and, Luke 3:17, burn up the chaff with 'unquenchable fire'.) There is one particular text in the Old Testament that is important to this subject, Malachi 4:1, 3: "For behold, the day is coming, burning like an oven, and all the proud, yes, all who do wickedly will be stubble ... For they shall be ashes under the soles of your feet on the day that I do this."

\footnotetext{
${ }^{1}$ Howard A. Peth, 7 Mysteries Solved, 7 Issues that Touch the Heart of Mankind, Second Edition, (Fallbrook, CA: Hart Books, 2002), 353.

2 "To quench a fire means to put it out. A fire that shall never be quenched is not one that shall never go out but one that cannot be put out." Ibid, 354 .
} 
Obviously the wicked people cannot be burning forever because the fire turns them to ashes and stubble.

Thus Seventh-day Adventists and a number of Protestant scholars consider the traditional teaching of eternal punishment ["hellfire"] to be un-biblical. ${ }^{1}$ For the Christian these truths provide relief and comfort knowing that a loving God will not engage in fiery punishment lasting into eternity, but the wicked will be completely annihilated and God will make all things new (Rev 20:9; 21:5). Additionally, Heaven would hardly be a place of unspoiled happiness if the righteous inhabitants had to watch other humans, including some loved-ones, burning throughout eternity.

\section{Purgatory}

Purgatory is a Catholic doctrine which was first given definite form in the writings of Augustine. ${ }^{2}$ Historically this has been the form: Purgatory is a sort of reformatory school for baptized Catholics who at death are not good enough to go directly to heaven. ${ }^{3}$ The Catholic Church teaches that "souls which depart this life in a state of grace but guilty of venial sins are liable to some punishment after the guilt of sins is forgiven, are subject to a process of cleansing before entering heaven." The souls

${ }^{1}$ http://www.geocities.com/pastorkeith/cullman 1.html?200521 Oscar Cullmann (2005). John Stott, the Logic of Hell: a Brief Rejoinder, Evangelical Review of Theology 18:1(1994):33-34. The Ministerial Association, Seventh-day Adventist Believe, A Biblical Exposition of Fundamental Doctrines, (Silver Springs, MD: Review and Herald Publishing Association, 1988), 369-370.

${ }^{2}$ http://home.computer.net/ cy/cy00026.html (2005)

${ }^{3}$ Philip Schaff, History of the Christian Church, Fourth Printing, Vol. 1, (Grand Rapids, MI: Wm. B. Eerdmans Publishing, 1960), 760. 
detained there (in purgatory) are helped by the prayers of the faithful. Purification is by fire and the fire is material. ${ }^{1}$

In 1997 the United States Catholic Conference issued its English copy of the Catechism of the Catholic Church with the following definition of purgatory. Purgatory, the Final Purification, is the place where all who die in God's grace and friendship, but still imperfectly purified, are indeed assured of their eternal salvation; but after death they undergo purification, so as to achieve the holiness necessary to enter the joy of heaven. This teaching of the Catholic Church is also based on the practice of prayer for the dead and commends almsgiving, indulgences, and works of penance undertaken on behalf of the dead. ${ }^{2}$

This current definition of purgatory is seen by some to be somewhat modified i.e., fire is omitted as a part of the Roman Catholic Church attempt at a unification process of all Christian churches under its jurisdiction. Protestants have always held the Purgatory teaching to be un-biblical.

I "Thomas Aquinas, Bonaventura, Gerson and other great men of the middle ages held that the fire of purgatory was material." Samuel Macauley Jackson and George William Gilmore, The New SchaffHerzog Encyclopedia of Religious Knowledge Vol. 9, (Grand Rapids, MI: Baker Book House, 1959), 364365 .

${ }^{2}$ Joseph Cardinal Ratzinger, Catechism of the Catholic Church, Second Edition, (Washington, DC: United States Catholic Conference, 1997), 268-270. 
APPENDIX F

FORGIVE AND FORGET NETWORK, INC

A LETTER OF INVITATION POSTER

BROCHURE

ROOM ASSIGNMENT 


\title{
FORGIVE AND FORGET NETWORK, INC \\ 2083 Lacey Oak Drive + Apopka, FL 32703 + 407-889-4921 \\ webbj@andrews.edu
}

August 8, 2003

Praise Fellowship SDA Church

Attn: Church Clerk

401 West Colfax Avenue

South Bend, IN 46635

Dear Church Clerk:

The purpose of this communication is to extend an invitation to your church. We are sponsoring a three day Grief Ministry Seminar at Andrews University in September. Enclosed is a copy of our flyer for your bulletin board and a brochure for your perusal. Please place this important announcement in your church bulletin and we look forward to seeing a representative from your church.

\author{
P E A C E OF M I N D \\ Grief Facilitator's Training Seminar \\ September 5-7, 2003 \\ 7:00 p.m. \\ Room N150 \\ Andrews Theological Seminary \\ Andrews University \\ Berrien Springs, MI 49104
}

For your information, seating is limited. For registration please contact me locally by phone at 269-471-6083 or email me at webbi@andrews.edu

Sincerely yours,

Chaplain Joyce M. Hatchett

/jmh

Enclosures 


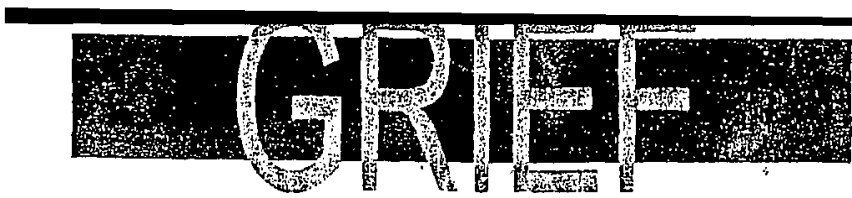

GRIEF - Most of us know and have experienced the reality of grief in one form or another. These experiences are viewed as a normal response to loss. It is as natural as the aging process. As sure as you live there will be losses.

The challenge for us is the suffering we have to endure when we lose a loved one through death - sudden death, expected death, anticipatory death or normal death. This loss affects our mind, our body, and our spirit.

After the death of a loved one, we are faced with two important questions that we must ask ourselves:

五

- Do I really want to resolve my loss issues?

- Do I really want to move beyond my grief to a richer and fuller. quality of life?

The opportunity is ones willingness to enter into the grieving process without delay. The event has come and gone, yet there lingers and lurks in the heart of humankind emotions -- anger, guilt, fear, bitterness and the overwhelming desire is have Peace of Mind.
There are approximately four distinct categories that we can observe death:

SUDDEN DEATH - involves heart attacks, seizures, overdose, strokes, and accidents of all kind.

\section{EXPECTED DEATH - includes termina] illnesses.}

\section{ANTICIPATORY DEATH - includes} Hospice patients.

NORMAL DEATH - is when a person dies of old age:

Regardless of how death happens, there are still emotional traumas that will follow. It is difficult to suppress these feelings without coming face to face with the pain later.

It is suggested and best to intentionally enter the grieving process in order to move toward health and healing. To procrastinate will cause the body, mind, and spirit to chose the time and place for you to grieve the loss. Sometimes it is done in unisons and at other times separately. Most of the times, it is unexpected and causes a unique set of feelings or physical symptoms.
For the Christian, HOPE is the key that unlocks the pain and instills in the heart the faith that conquerors grief.

Paul pemued these words to the Thessalonians, "But we do not want you to be uninformed, brothers and sisters, about those who died, so that you may not grieve as others do who have no hope. For since we believe that Jesus died and rose again, even so, through Jesus, God will bring with him those who have died . . . therefore comfort one another with these words."1 Thessalonians 4:13-18 (NRSV).

PEACE OF MIND SEMINAR is for you because:

- You want to resolve your loss issues.

- You want to move beyond grief to a richer and fuller quality of life.

- You are called to minister to the needs of those around you who are grieving

- You have HOPE in the Lord Jesus Christ.

- You have found Bible promises that anchors your FAITH.

- You need your JOY restored. 
11:30am 12:30pm THST550-Prin of Christian Ethics (Kis)

12:30pm 1:30pm THST510-2 Revelation, Inspiration, Herm. (vBemmelen)

1:30pm 3:30pm Doct Sanctuary (R. Gane)

3:30pm 6:30pm GSEM525-1-Bible \& Bib Hist (Staff)

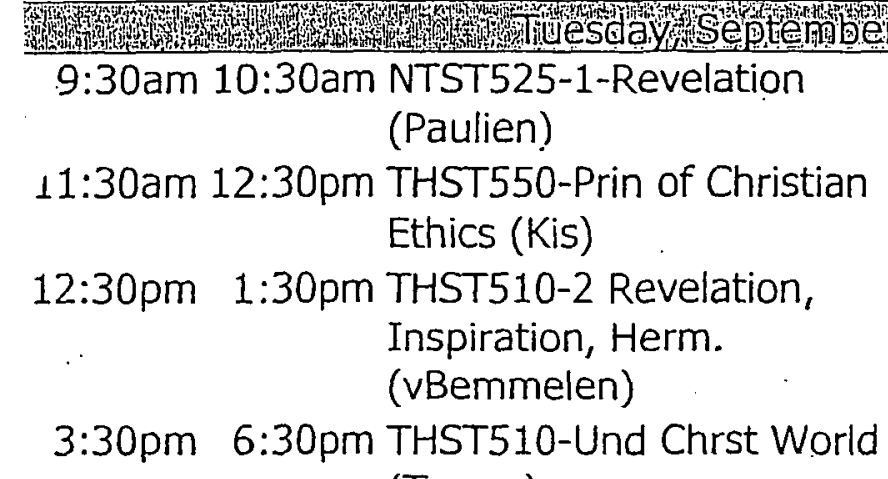
(Toews) 7:00pm 9:00pm Grief Seminar

(loyce-471-6028 (North))

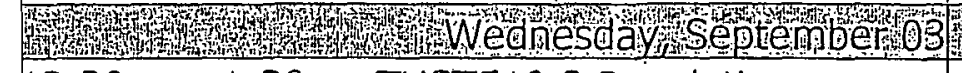

12:30pm 1:30pm THST510-2 Revelation, Inspiration, Herm.

(vBemmelen)

1:30pm 3:00pm MTST543-1-Acts \& Gen Epis (Johnston)

3:30pm . 5:30pm GSEM525-1-Bible \& Bib Hist (Winkle) 10:00am 11:30am Sabbath School Class (Dr. Dederen)

3:00pm 6:00pm Grief Seminar

(Joyce-471-6028)

Fry

9:00am 12:00pm Grief Seminar

(Joyce-471-6028) 
APPENDIX G

OPTIONAL PROGRAMMING

SERVICE OF REMEMBRANCE

ROSEBUD CEREMONY

WE REMEMBER 


\section{SERVICE OF REMEMBRANCE \\ For \\ Antony J. Harris}

Wednesday, February 25, 2004

Andrews University Seminary Chapel

$$
\text { 7:00 p.m. }
$$

\begin{tabular}{|c|c|}
\hline Opening Song "I Come to The Garden Alone" & Congregation \\
\hline Opening Prayer/Welcome & Stephen Steward \\
\hline Obituary & Sandra Johnson \\
\hline Words of Hope & $\begin{array}{l}\text { 1) Joyce Rickman } \\
\text { 2) Tony Harris } \\
\text { 3) Faith Harris }\end{array}$ \\
\hline "Walk With Me" & $\begin{array}{l}\text { Wanda Cantrell } \\
\text { Bob }\end{array}$ \\
\hline Homily & Chaplain Joyce M. Hatchett \\
\hline Special Music "What A Friend We Have In Jesus" & Tenia Lewis \\
\hline $\begin{array}{l}\text { Rose Bud Ceremony } \\
\text { ("It Is Well With My Soul") }\end{array}$ & $\begin{array}{l}\text { 1) Tessine Watson } \\
\text { 2) Tom Gibson }\end{array}$ \\
\hline Special Music "We Shall Behold Him" & Signing Group \\
\hline "WE REMEMBER" & $\begin{array}{l}\text { Congregation } \\
\text { Marva Drigo-Dennis }\end{array}$ \\
\hline Benediction & Chaplain Joyce M. Hatchett \\
\hline
\end{tabular}

Pianist:

Organist: Dr. James North

Mistress of Ceremony: Adrianne Townsend 


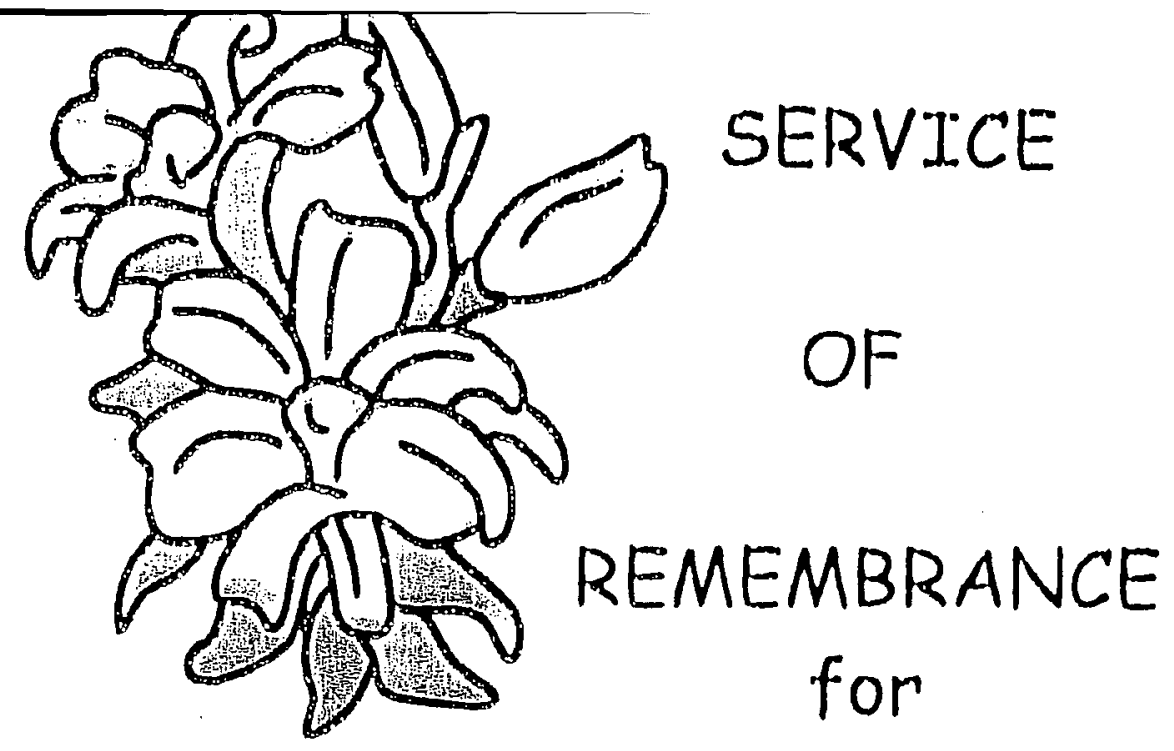

$\vec{\infty}$

\author{
Aritony J. Harris \\ (Son of Bradley \& Sally Gantt-Smith) \\ Seminary Family Deaths
}

Wedinesday, Felwuary 25, 2004

7:00 P.M.

Seminary Chapel

Andrews University

Berrien Springs, MI 


\section{ROSE BUD CEREMONY}

Joyce M.Hatchett

Reader 1: Let this $\boldsymbol{R} \boldsymbol{O S} \boldsymbol{E}$ signify the ever present love and memory that will always live on in our hearts. At the same time, let this $\boldsymbol{R} \boldsymbol{O S E}$ symbolize the renewal we must seek as we continue life without our loved ones whom we love and strive to walk on with others.

Reader 2: As we contemplate placing our $\boldsymbol{R O S E}$ in the vase, we imagine that it will symbolize the love and loss we have experienced.

We all have holes in our lives because our loved one has died, but we are thankful we can share with each other. Together we find hope and healing in sharing. May we share and divide our pain.

Reader 1: As we place our $\boldsymbol{R O S E}$ in the vase, in remembrance, we do so as those who care, those who share, and those who remember.

Reader 2: As the music is being presented, please come forward bringing your ROSE, and place it in the vase.

It is at this table that we begin to accept our loss while continuing to remember our loved ones who meant so much to us. 


\section{We Remember Them}

In the rising of the sun and its going down, We Remember Them.

In the bowing of the wind and in the chill of winter, We Remember Them.

In the opening of the buds and in the rebirth of spring.

We Remember Them.

In the blueness of the skies and in the warmth of summer, We Remember Them.

In the rustling of the leaves and in the beauty of autumn.

We Remember Them.

In the beginning of the year and when it ends, We Remember Them.

When we are weary and in need of strength, We Remember Them.

When we are lost and sick of heart, We Remember Them.

When we have joys and special celebrations we yearn to share, We Remember Them.

Sp long as we live, they too shall live, for they are part of us.

We Remember Them.

$\sim$ From the Jewish Book Of Prayer 


\section{APPENDIX H}

DOCTRINE OF LAST THINGS QUESTIONS

CHAPTER 23: CHRIST'S MINISTRY IN THE HEAVENLY SANCTUARY CHAPTER 24: THE SECOND COMING OF CHRIST

CHAPTER 25: DEATH AND RESURRECTION

CHAPTER 26: THE MILLENNIUM AND THE END OF SIN

CHAPTER 27: THE NEW EARTH

CONTRACTUAL AGREEMENT 


\title{
THE DOCTRINE
}

OF

\author{
LAST THINGS
}

QUESTIONS 


\section{CHAPTER 23: Christ's Ministry in the Heavenly Sanctuary}

1. Why did Christ have to become the Sacrificial Lamb, to die for the sins of the World?

2. As our High Priest serving at the right hand of the Father, what are two functions that Christ demonstrates?

3. What are the three phases of Christ's Ministry illustrated in the Sanctuary?

4. Because not all who choose to be Christians are not genuine disciples, what does the garment represent at the wedding feast?

What does the Church, clean and white signify?

5. What is central to the message of the good news of Christ's closing ministry? 


\section{CHAPTER 24: The Second Coming of Christ}

1. What did the early Christians and the Apostles consider Christ's return as? And why?

2. What warnings did Christ speak about as signs that His coming is near?

3. Will Christ's coming be visible to everyone?

4. Name five (5) events the Bible indicates as signs of the end times?

5. What is the threefold message God sent of warning to prepare the world for Christ's return? 


\section{CHAPTER 25: Death and Resurrection}

1. What does the Bible tell us about the wages of Sin?

2. What does the Bible say about hope for humanity?

3. What is the Biblical representation of death?

4. The Bible speaks of the First and Second Death, what are they?

5. What has Christ's resurrection done for us?

6. What are the two resurrections that the Bible speaks of? 
CHAPTER 26: The Millennium and the End of Sin

1. What does the Bible say will happen to the forces of evil for $\mathbf{1 , 0 0 0}$ years (or the Millennium) between the first and second resurrection?

2. When will Christ's enemies be slain?

3. Will the wicked be tormented forever?

4. What is the principle of punishment?

5. What happens at the final cleansing of the Earth? 
1. How does the Bible describe the New Earth?

2. What are some of the physical descriptions of the new Earth?

3. What are some activities in the New Earth?

4. Shall former thing be remembered?

5. How shall God's character be revealed? 


\section{Contractual Agreement}

by Joyce $M$. Hatchett

Name: Phone\#:

Address:

City: State: Zip Code:

My initials and signature on the lines below is to acknowledge that I have completed the following requirement:

$\checkmark$ I have read the following chapters regarding the Doctrine of Last Things from the Seventh-day Adventists Believe: A Biblical Exposition of 27 Fundamental Doctrines (pages 311-383).

Chapter 23: Christ's Ministry in the Heavenly Sanctuary Chapter 24: The Second Coming of Christ Chapter 25: Death and Resurrection Chapter 26: The Millennium and the End of Sin Chapter 27: The New Earth

$\checkmark$ I have answered the questions for each of these chapters and submitted them to the Grief Ministry Coordinator.

Date:

Signature of Participant

Date: 


\section{APPENDIX I}

CERTIFICATES OF TRAINING

BASIC ADVANCE 


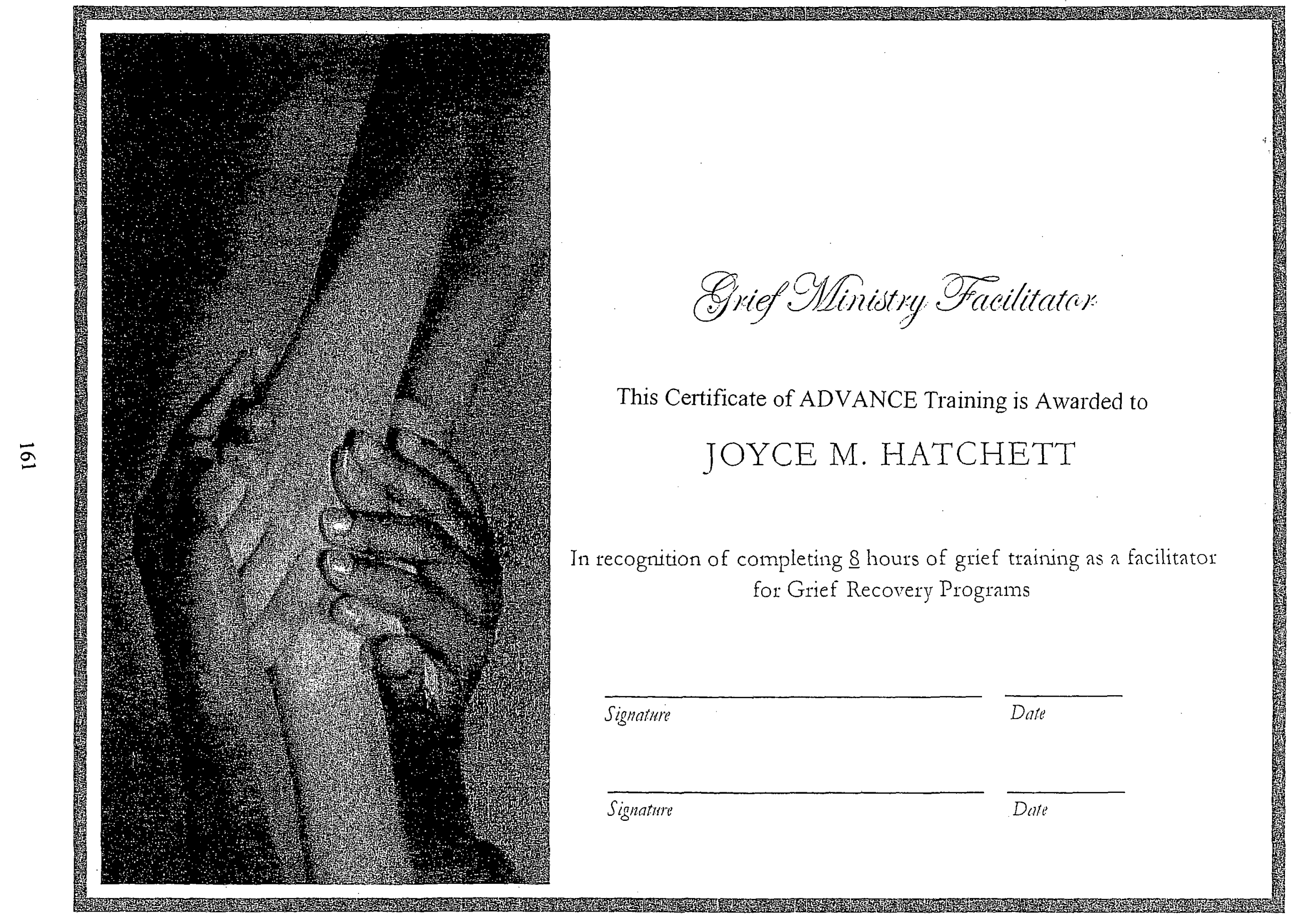




\section{APPENDIX J \\ HOSPICE FOUNDATION SAMPLERS \\ A LETTER OF INVITATION \\ REGISTRATION \\ EVENT SCHEDULE}



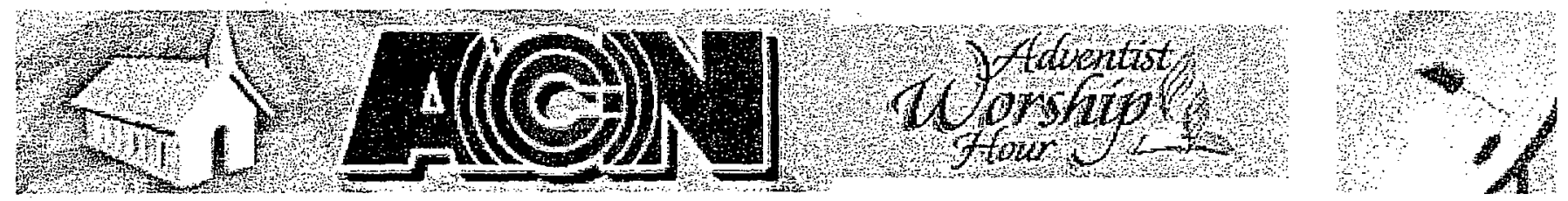

ADVENTIST CONMUNICATION NETWORK

- Home

- Schedule

- Bulletin

- Equipment

- Tech Support

- Registration

- Upcoming Events

- Online Catalog

- Onime Videos

- DVD Support

- Contact Us

- Links

\section{A letter of invitation}

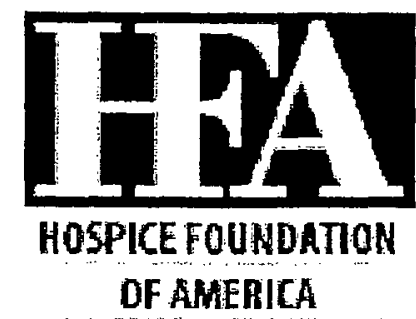

2001 S Street, NW, Suite 300

Washington, DC 20009

Get these free plugins:

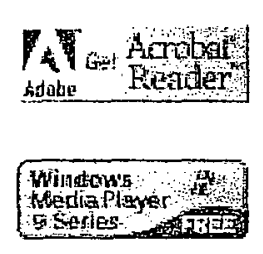

Date: November 2003

To: $\quad$ All Adventist Communication Network (ACN) Members Hospice Foundation of America

From: Karen Higgins, Manager 11th Annual National Bereavement Teleconference

Subject: Living With Grief: Alzheimer's Disease

For three years, ACN and HFA have worked together to promote and present the annual Living With Grief teleconferences. ACN members have served as host sites, publicized the teleconference, and invited interested members of the public to participate. For our 2003 program, Living With Grief: Coping with Public Tragedy, ACN contributed footage from its own compelling production based on the events of September 11, 2001.

We truly value this partnership.

Living With Grief: Alzheimer's Disease will be broadcast live-via-satellite on Wednesday, April 28, 2004. Once again, our moderator will be Cokje Roberts, of ABC News. The program will cover what is known medically about Alzheimer's, describe innovative programs for patients and caregivers, explore grief issues faced by patients and families, and discuss relevant public policy issues.

Once again, HFA invites you to register as a host site. Site registration fees will be waived for all ACN members. A registration form is attached, or you can register on-line at www. hospicefoundation.org

If you have questions, please call me at 800-854-3402. I will be happy to help, and I look forward to working with you. Please join us.

Home | Bulletin | Equipment | Registration | Schedule | Video | Orders | Contact Us | Links 


\section{Hospice Foundation of America \\ $11^{\text {th }}$ Annual Living With Grief Satellite Teleconference Living With Grief: Alzheimer's Disease \\ Wednesday, April 28, 2004 • 1:30-4:00 p.m. EDT<smiles>[13CH3]</smiles>

Why host a downlink site for our award-winning Annual National Bereavement Teleconference?

- Serves as a tool to increase awareness of your organization in your community

- Offers an opportunity to build relationships with other caregivers, advocates, and community leaders

- Helps frontline healthworkers, family caregivers and advocates stay current on end-of-life topics

- Offers an opportunity for low-cost continuing education credit to nurses, social workers, physicians, funeral directors, counselors, clergy, EMS workers and others
When you register, you receive:

- A comprehensive Site Coordinators Manual (in January)

- Onsline media and publicity materials to help promote your event

- Technical information for KU-and C-band satellites (in February)

One free copy of the companion book with reduced prices for additional copies

- Special access to teleconference material's on HFA's website

- Teleconference updates via email

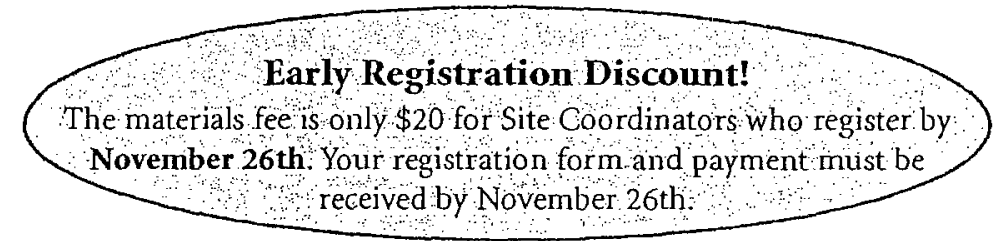

There is a materials fee of $\mathbf{\$ 2 5}$ to register as a downlink site for the teleconference. (No purchase orders) THREE WAYS TO REGISTER:

1. MAIL this registration form with a check, money or credit card \#

2. FAX this form and use a credit card to: 202-638-5312

3. Register ONIINE and use a credit card at: www.hospicefoundation.org

REGISTRATION FORM (The registered Site Coordinator will receive information and materials by mail.)

Please print clearly.

Site Coordinator

Organization

Address

City

State

Zip

Phone ( )

Email (required)

VISA/MC/AMEX \#

Cardholder Name (print)

Exp.

YES NO

1. Is this your first time hosting a HFA teleconference site?

2. Will you be hosting multiple sites?

$\square \square$

$\square$

3. HFA publishes an online list of registered Site Coordinators $\quad \square \quad \square$ to assist people looking for a teleconterence location in their area. Would you like your contact info on HFA's online site coordinator list?

Sites registering after April 2, 2004 must access Site Coordinator's materials online and may not be listed on HFA's online teleconference list.

Payment must accompany this form: Please do NOT send separately. If you would like more than one set of materials, you must submit an additional $\$ 25$ for each set requested. 


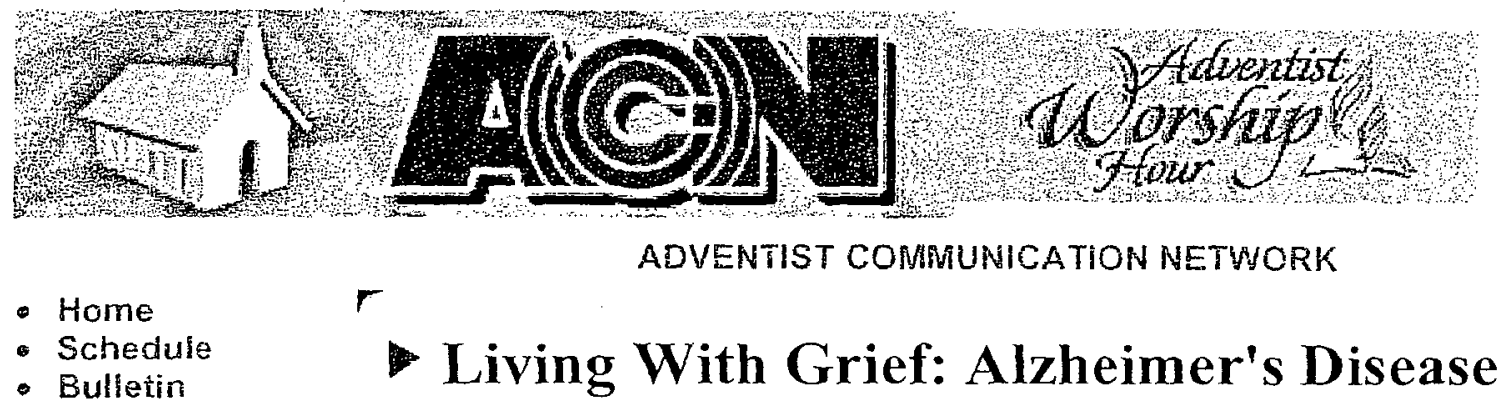

- Bulletin

- Equipment

- Tech Support

- Registration

- Upcoming Events

- Online Catalog

- Online Videos

- DVD Support

- Contact Us

- Links

Get these free plugins:

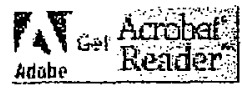

\section{April 28, 2004 \\ 1:30-4:00 pm ET}

\section{Hospice Foundation Teleconference}

HFA's 11th Annual National Bereavement Teleconference will focus on "Living With Grief:(A) Alzheimer's Disease." This program, moderated by Cokie Roberts of ABC News, will be broadcast Wednesday, April 28 from 1:30pm to 4:00pm EDT. An expert panel will discuss what is known medically about the diagnosis, progression, and treatment of the disease; explore some innovative programs for patients and caregivers coping with Alzheimer's; focus on the particular grief issues that patients and families face during the course of this illness; and examine the challenges and opportunities that Alzheimer's disease presents to clinicians, caregivers, hospice workers, and policy advocates. The panel also will discuss dementias other than Alzheimer's.

Ms. Roberts will lead a panel of noted authorities to include: Kenneth J. Doka, PhD, College of New Rochelle; Parag Dalsania, MD, Veterans Affairs Medical Center; Lisa Gwyther, MSW, LCSW, Duke Medical Center; William Haley, PhD, University of South Florida; Richard Ham, MD, West Virginia University Center on Aging; Lin Noyes, RN, PhD, Alzheimer's Family Day Center; and Therese Rando, PhD, Institute for the Study and Treatment of Loss.

Home | Bulletin | Equipment | Registration | Schedule | Video | Orders | Contact Us | Links Website design, hosing and ecommerce by riosiord Web Service 


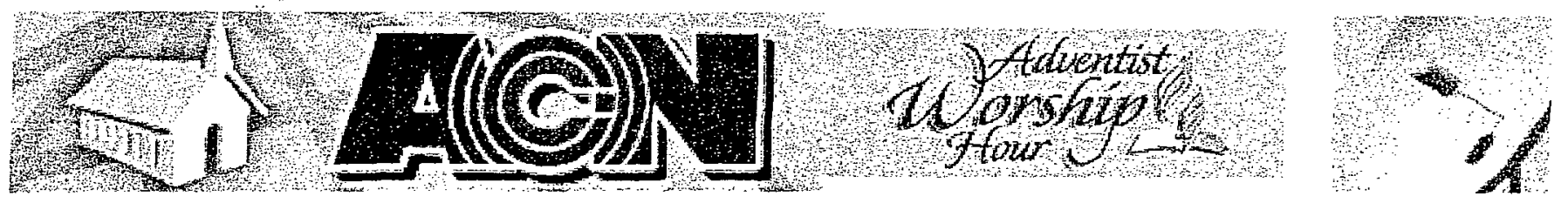

ADVENTIST COMMUNICATION NETWORK

- Home

- Schedule

- Bulletin

- Equipment

- Tech Support

- Registration

- Upcoming Events

- Online Catalog

- Online Videos

- DVD Support

- Contact Us

- Links

\section{Ministry Professional Growth Seminar}

THEME: Bridge Building: Clergy as Designers of Reconciliation

DATE: $\quad$ March 30, 2004

TIME: $\quad 1: 00-4: 30 \mathrm{pm}$ ET

TO REGISTER: $301-680-6518$

104474.206@compuserve.com

www.ministerialassociation.com

Get these free plugins:

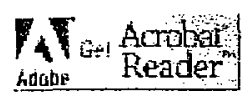

\section{Hospice Foundation Teleconference}

TOPIC: $\quad$ Living With Grief: Alzheimer's Disease

Whindows
Mediaflater
s.teries

DATE:

April 28, 2004

TIME:

1:00-4:30 pm ET

TO REGISTER: www.hospicefoundation.org

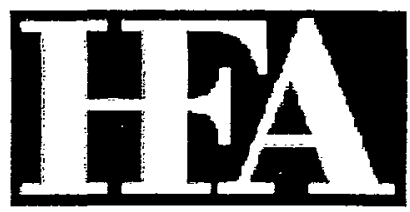

HOSPICE FOUNDATION

OF AMERICA

\section{Program Description}

\section{A letter of invitation from Karen Higgins, Hospice Teleconference manager}

Pastors and lay leaders, put these important programs on your calendar and in your tickler file. Both of these excellent programs.

Why should my church participate?

1. Service to the community

2. Strengthen presence of the local Adventist Church in the community

3. Open Adventist church to the community

4. Become friends with community professionals

5. Establish credibility of the world-wide Adventist Church

Adventist congregations should ever be seeking opportunities to serve the community. These two programs are easy ways to accomplish that. The programs are already planned and will come to you via your satellite system.

Minimal preparation is required.

1. Register with the organization.

Registration is important in order to receive advertising materials and registration materials for participants at the host site.

2. Invite your target group. 
to present the message

8:30 - Uplink fades to black

REGISTRATION: Call $800-A C N-1119$ or register

online at www.acn.info

(Registration begins March 1)

Free materials for registered sites:

\author{
1. NET 2004 Planning Manual \\ 2. Samples of direct mail \\ advertising materials with \\ order form \\ 3. Audio Tapes of sermons by \\ Walter Pearson \\ 4. Samples of Walter \\ Pearson's book \\ 5. Backup video tape of \\ Pearson's sermon, for use if \\ satellite transmission is poor \\ 6. Access to faster and better \\ ACN technical support
}

\footnotetext{
Home | Bulletin | Equipment | Registration | Schedule | Video | Orders | Contact Us | Links

Website design, hosing and ecommerce by Hosford Web Service
} 
Professional Growth Seminar: Local pastors of every denomination

Hospice Teleconference: Pastors, nurses, healthcare professionals, funeral home directors, counselors, local hospice professionals, hospital chaplains, social workers, nursing home administrators and employees, and Alzheimer's care professionals.

3. Make sure your church and yard are ready for company.

A clean, organized environment always makes a good first impression.

4. Make sure your satellite equipment is working.

Check your satellite system by using it for another program before the scheduled event. Call $800-\mathrm{ACN}-1119$ for technical assistance if necessary.

5. Supply water and snacks. (light lunch if during the noon hour in your time zone)

Bottled water or pitchers of ice water on tables. Light refreshments during the break.

6. Be on site to welcome your guests.

A friendly host will put everyone at ease. Try to anticipate the needs of your guests. Instructions to restrooms, coatrooms, telephones etc will be helpful. 
APPENDIX K

GRIEF MINISTRY FACILITATOR'S TRAINING MANUAL 


\section{GRIEF MINISTRY}

\section{FACILITATOR'S TRAINING}

\section{MANUAL}

Joyce M. Hatchett, DMIN

July 2005 


\section{TABLE OF CONTENT}

Page\#

INTRODUCTION $\quad$.......................................... 173

GRIEF FACILITATOR REQUIREMENTS ................... 174

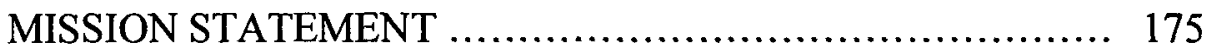

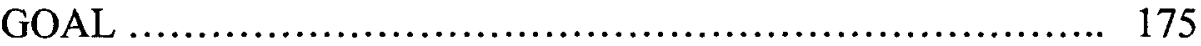

OBJECTIVES ............................................... 175

GRIEF FACILITATORS' TRAINING

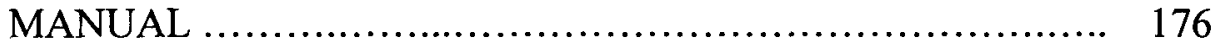

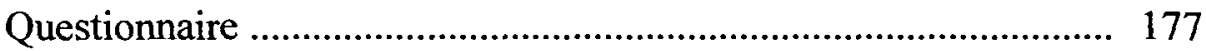

SESSION 1: Let's Get Acquainted ……………….................... 178

Song: "In The Garden"................................................... 179

Oxygen Mask ........................................................... 180

Stress Level ............................................................ 181

Mind/Body/Spirit ......................................................... 182

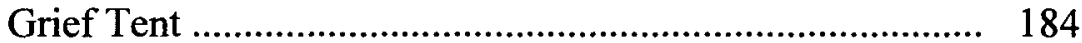

Brain Freeze .................................................................. 185

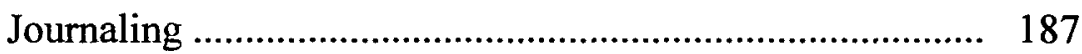

SESSION 2: EXPERIENCING GRIEF .................................... 189

Defining Loss .............................................................. 190

Emotions ….................................................................. 192

Part 1: A Look At Problems in Grief ................................ 195

Adapting to Loss ............................................................. 196

Grief Time Schedule ..................................................... 197

Letting Go.................................................................. 198

Part II: A Look At Problems of Grief ................................ 200

Things to Do ................................................................. 201

Itsy Bitsy Criticism Committee Reporting Form ............. 202

Serenity Prayer .............................................................. 203 
Stages of Death (Elisabeth Kubler-Ross) ........................... 205

Stages of Grief(Granger Westberg) ................................... 208

Grief Model by Theorist .................................................... 209

Stress Management and Relaxation .................................. 210

Breath Prayer ................................................................ 212

SESSION 4: PEACE OF MIND PART I: LONELINESS ............. 215

Kind of Loneliness ....................................................... 216

State of Loneliness …………………….......................... 217

Chronic Loneliness ........................................................ 218

Parable/Life.................................................................... 219

God's Personalized Plan .................................................... 223

Scripture Assurance .......................................................... 225

SESSION 5: PEACE OF MIND PART II:

FIVE TOPICS FOR GRIEVERS.............................. 228

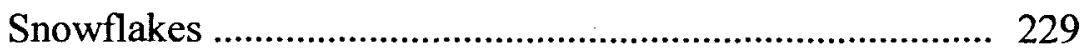

You Are Valuable ........................................................ 231

New Heart ................................................................... 232

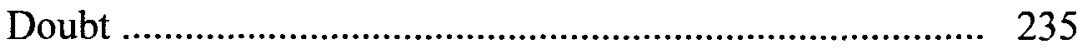

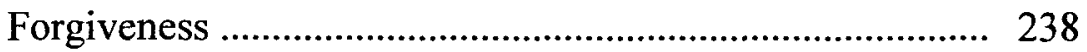

SESSION 6: BIBLICAL ROLE MODEL …................................. 241

Abraham …................................................................. 242

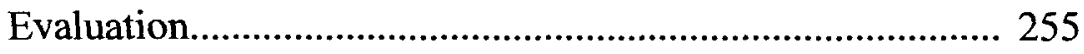




\section{INTRODUCTION}

Welcome to Grief Ministry! Grief is an emotion that we experience whenever we have a loss. As human beings we grieve in many different ways. Over a lifetime we will experience grief many times in some form because loss is a natural part of life that we cannot escape.

There is one area of loss that creates more emotional pain than we are able to bear alone and that is the loss of a loved one. This is our area of specialization. We will focus only on this area although it is evident that death touches many areas of life.

When a loved one dies, this can be the most devastating experience in a person's life. The death can become overwhelming and traumatic in nature. The griever(s) should not have to go through this time of suffering alone, especially when they are a part of a faith community. Most of us have lost someone we loved and can sympathize with those who are now in the midst of their pain. After the funeral when everyone has returned to their lives as usual, there are feelings of being alone, feelings of sadness or anger or frustration that will not go away. There is a desire to get rid of or lessen this pain. The tears may not stop. There is no one to talk too. The questions are, "Who do I turn to?" "Where do I go for help?"

We would like to suggest that you contact your local Grief Ministry Facilitator who can help in this time of need. This spiritual leader can provide guidance to help you mentally, physically, emotionally and spiritually. This individual has been trained to 
become a resource person who provides who provides grief assistance or points you to those who are able to assist you during this time of uncertainty.

\section{GRIEF FACILITATOR REQUIREMENTS}

Grief Facilitation, I believe is a call from God to minister to the needs of those who are grieving the death of a loved one. It is best for the facilitator to be a mature adult, preferably someone who has experienced the death of a loved-one.

Because this is denominational program, three pre-requisites are listed below: 1) The facilitator has to read the following chapters in the book Seventh-day Adventist Believe: A Biblical Exposition of 27 Fundamental Doctrines, published by the Seventhday Adventist General Conference Ministerial Association: Doctrine of Last Things (pages 311-383).

- Chapter 23 Christ's Ministry in the Heavenly Sanctuary

- Chapter 24 The Second Coming of Christ

- Chapter 25 Death and Resurrection

- Chapter 26 The Millennium and the End of Sin

- Chapter 27 The New Earth

To assure that these chapters have been read there are 5-6 questions per chapter. Each facilitator must sign a statement that they have read these chapters and submit the answers to the questions. 2) The facilitator must read Hebrews 11: 1-22 and Genesis 11:27 - 25:11 for discussion of Abraham as a Biblical Role Model. 3) The facilitator must attend A Grief Ministry Facilitator's Training Seminar and receive a certificate of completion. 


\section{MISSION STATEMENT}

To help those who are grieving the death of a loved one gain the assurance and reassurance that they are not alone in their grief by training grief ministry facilitator in the Adventist Church. These facilitators will provide nurture to an individual or a small group by walk along side of them during this difficult time in their live as they do their grief work.

\section{GOAL}

To provide an annual grief ministry training program for facilitators in the local Adventist church. And to train new facilitators who will intentionally minister to the bereaved in their local congregation and community.

\section{OBJECTIVES}

- To establish a continuous grief ministry training program to update facilitators on current issues and updates in the area of grief and grief recovery.

- To heighten awareness of grief needs in local congregation and community that needs to be addressed by the grief facilitator.

- To provide spiritual support for facilitators who find themselves overwhelmed with the grief in their local church or community through networking.

- To become a resource for facilitators who are seeking grief professional in their community, city, state, and national level who can provide special services to the bereaved 


\section{GRIEF MINISTRY FACILITATOR'S TRAINING SEMINAR}

A Grief Ministry Facilitator's Training Seminar consists of eight (8) one hour sessions. These seminars can be conducted during the week of camp meeting, conference training session, or as an intensive three day seminar - preferably Friday, Saturday and Sunday.

The material and training for this ministry can be the foundation for a Grief Recovery Program in the local church. The facilitator's training seminar materials and exercises can be transposed into a Grief Recovery Program that runs for one hour per week and can be offered to the local congregation and/or the community.

If you are considering a Grief Recovery Program for your church it is suggested that you contact us for a presentation packet:

Forgive and Forget Network Incorporated Joyce M. Hatchett, DMin 2083 Lacey Oak Drive Apopka, FL 32703

407-310-8920

joyceh@aim.andrews.edu 
Name:

Phone\#:

Address:

City:

State:

Zip Code:

Status: Married Single Divorced Widow Widower

Education: High School Undergraduate Graduate

Occupation: Pastor Laity Professional Retired

Age: $18-25$ 26-35 $36-45$ $46-55$ $56-65$ $66+$

Time: How long has it been since your loved one died?

0-6 months 7-12 months $1-5$ years $6+$ years

Number: Give a numerical number of the number of deaths you have had during the above time periods.

0-6 months

7-12 months 1-5 years $6+$ years

Categories: How would you categorize your most current loss?

$\begin{array}{llll}\text { Normal } & \text { Expected } & \text { Anticipated } & \text { Sudden } \\ \text { (Old Age }) & \text { (Terminal Illness) } & \text { Not Sure } \\ \text { (Hospice) }\end{array}$

\section{Emotional:}

Has this death caused you emotional trauma?

YES

NO

Have you experienced a physical manifestation of your grief?

YES

NO

Has the Bible been a spiritual resource for you?

YES

NO

Has the Bible helped you in your understanding of dezth and dying? YES

$\mathrm{NO}$

Has the Church/Faith Community been supporive to sou and your family?

YES

NO

Do you feel like God is responsible for the at vour woved one?

YES

NO

Do you have a sense of your Grief?

YES

NO

Are you willing to do your own Grief Work?

YES

NO

Physical Symptoms: I have experienced the following physical symptoms of my grief.

Sleep Patterns Low Energy Weight Gain/Loss I Get Less Done Other 


\section{SESSION 1}

\section{LET'S GET ACQUAINTED}

Song: "In The Garden".

Oxygen Mask

Stress Level

Mind/Body/Spirit

Grief Tent

Brain Freeze

Journaling

Exercises: Brain Freeze/Journaling 


\section{In the Garden}

John 20:15-17

C. Ausin Miles, 1912 (1868-1946)

Irregular

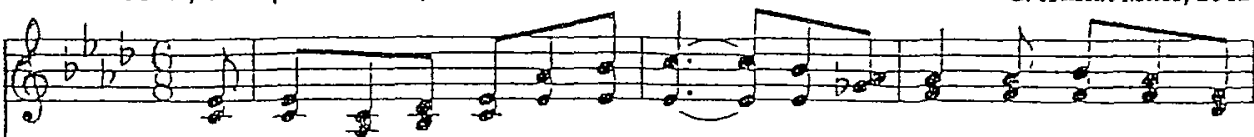

1. I come to the gar-den a - lone,

2. He speaks, and the sound of His voice

While the dew is sill on the

3. I'd stay in the gar-den with $\mathrm{Him}$

Is so sweet the birds busin tineir

Though the night a-rounc me be
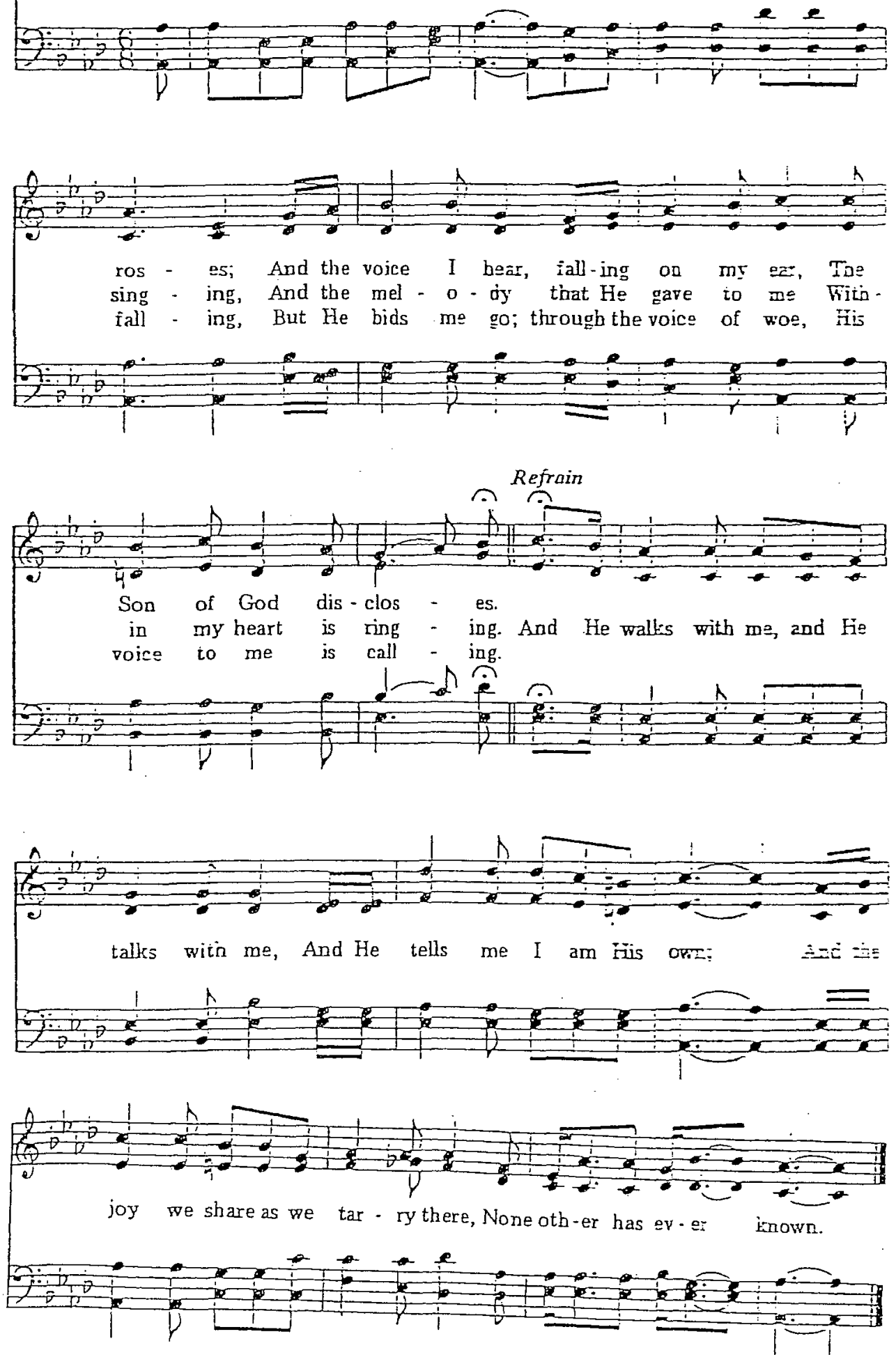


\section{OXYGEN MASK}

(Use the analogy of the stewardess on the airplane who gives the safety instructions before the plane takes off, in case of an emergency.)

BEFORE YOU CAN HELP SOMEONE ELSE (Family or Friend) YOU MUST FIRST HELP YOURSELF.

- PUT THE OXYGEN MASK ON YOURSELF

- BREATH DEEPLY (although the mask may not expand there is oxygen flowing) When others see you are healing they will want it too.

- THEN PLACE THE MASK ON THE OTHER PERSON (The sick cannot help the sick.) You are able to help others through their grief crisis.

This is the reason we are all here to get the help we need so that we can help others who are in Grief and need our help - family, friend, or foe.

\section{GOD}

\section{HIS WORD}

\section{FAITH COMMUNITY}

PAIN ABATED 


\title{
STRESS LEVEL
}

The distribution of the "Self - Assessment On Life Events," the seriousness of developing an illness or change of health comes with the number of changes in ones life.

- This assessment can be give to each participant as they return the registration form. This will expedite time or you can give it out after you have come together as a group.

- Have each individual tabulate their own score. It is suggested that this score not be shared with the group - confidential.

- This score will give the individual a pretty good idea as to where they stand stress wise and the immediacy of the attention that needs to be given to their health.

\section{SELF-ASSESSMENT}

\author{
ON
}

\section{LIFE EVENTS}




\section{SELF - ASSESSMENT ON LIFE EVENTS}

Name

Date

Below are listed events which occur in the process of living. Place a check mark in the left-hand column to each of these events that have happened to you during the last 12 months.

\section{LIFE EVENTS}

Death of a Spouse

Divorce

Marital Separation

Jail Term

Death of Family Member

Personal Injury or Illness

Marriage

Fired From Work

Marital Reconciliation

Retirement

Change in Family's Health

Pregnancy

Sex Difĩculties

Addition to Family

Business Readjustment

Change in Financial Status

Death of a Close Friend

Change to Difierent Job

Change in Number of Arguments

Mortgage/Loan OVER \$10,000

Foreclosure of Loan

Change in Job

Child Leave Home

Trouble with In-law's

Outstanding Achievement

Spouse Begins'Stops Wot:-

Starting/Finisning Schoo:

Change in Environmen:

Revision of Habits

Trouble with Boss

Change in Work Hours

Change in Schools

Change in Residence

Change in Recreational 5 isis

Change in Church Acriviies

Change in Social Activities

Mortgage or Loan UNDER \$10,006

\section{POINTS}

100

73

65

63

63

53

50

47

45

45

41

40

39

39

39

38

37

36

35

31

30

29

29

29

29

26

20

25

24

23

20

20

20

19

19

18

17 
Self-Assessment on Life Events, continued

Change in Sleeping Habits

Change in Family Gatherings $\quad 14$

Change in Eating Habits $\quad 12$

Vacation 11

Festival Holidays 10

Minor Violation of the Law 10

SCORE

SCORING INTERPRETATION:

If you scored:

150 or less

You have a 30 percent chance of developing an illness or change of health in the next two years.

$151-299$

You have a 50 percent chance of developing an illness or change of health in the next two years.

$300 \&$ up

You have an 80 percent chance of developing an illness or change of health in the next two years.

Accoraing to Holmes and Rehe, ${ }^{1}$ the seriousness of illness increases with the number of changes in your life. So, the lower your score, the less chance you have of becoming seriously ill. You can, of course, work to prevent illness by setting your prionities.

'T. H. Holmes and R. H. Rahe, "The Social Requirement Raring Scale," Jouma o" - Esyonoiogizal Research 11 (1967), 213. There is also a Life Change Scale for Youth written by M. B. MaO T, F. Garig; and F. R. Bowers, "The Influence of Recent Life Experience and the Health of College Fresimmen, "Jounal of Psvchosomatic Research 19 (1975): 91. 
G R I E F

G R I E F

G R I E F

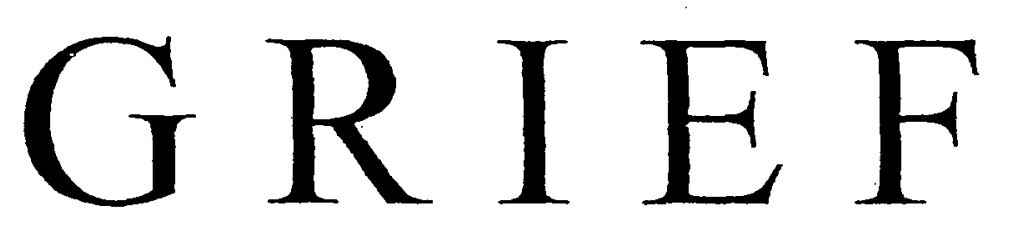

G R I E F

G R I E F

G R I E F 


\section{BRAIN FREEZE}

by Joyce M. Hatchett

The Brain Freeze is an exercise in which the

participant is encouraged to write the name of their most

recent death(s) on lines in the picture of the brain.

The idea is to connect the mind and hand. This allows

for the exercise to be like the melting of an ice cube-

giving self permission to pull from the subconscious to the

conscious (Mind over Matter) - and journaling these

thoughts.

Some will be resistant to this thought of writing on the

brain so allow them to write it on the lines below. 


\section{BRAIN FREEZE}

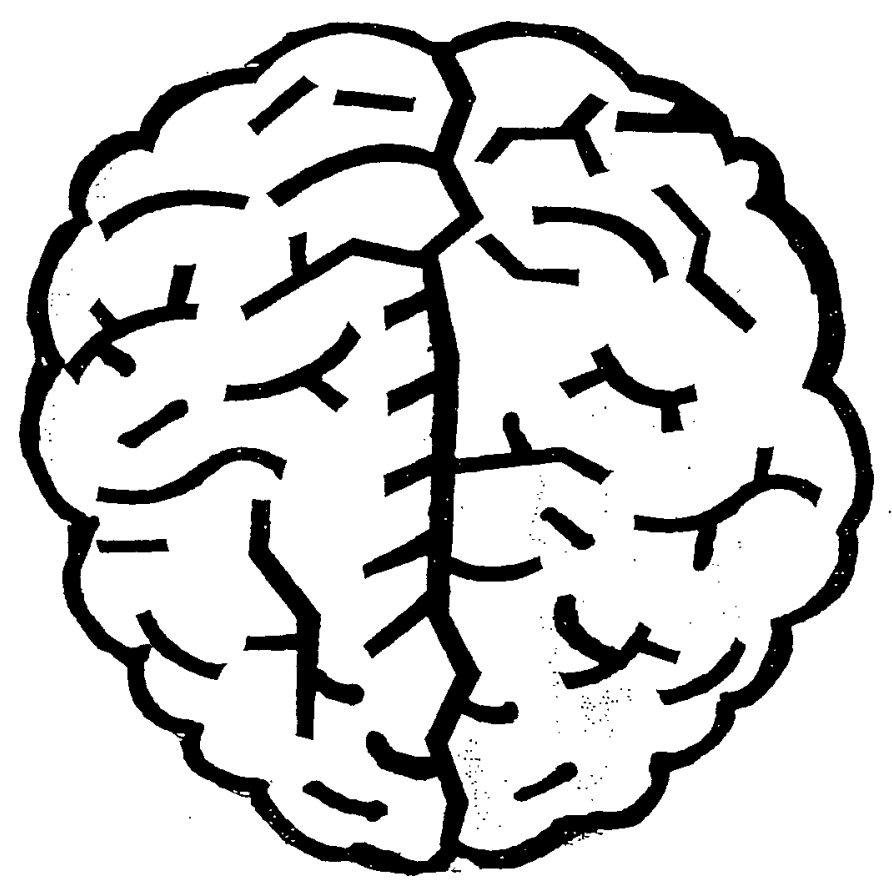

Place your most recent death(s) on one of the groves of the brain or on the lines below.

$+$

t

$*$

*

$+$

. 


\section{JOURNALING}

Journaling is a way to process one's grief by writing down thoughts and memories.

Journaling is not for everyone because many people do not like to write.

Journaling can be done creatively by pasting things in a book or drawing pictures as thoughts and memories manifest themselves spontaneously.

Journaling can be both writing and creativity. 
Date:

(Story of a significant loss in my life. Please write this story before our next meeting and be prepared to share it with your small group during the spiritual growth time.) 


\section{SESSION 2}

\section{EXPERIENCING GRIEF}

Defining Loss

Emotions

Part 1: A Look At Problems in Grief

Adapting to Loss

Grief Time Schedule

Letting Go.

Part II: A Look At Problems of Grief

Things to Do

Itsy Bitsy Criticism Committee Reporting Form

Serenity Prayer

Exercise: Itsy Bitsy Criticism Committee (IBCC) 


\title{
EXPERIENCING GRIEF
}

\section{DEFINE LOSS}

\author{
Examples:
}

Moment of Birth: Evacuated from the womb.

Childhood: Bottle or Breast Feeding; teeth; when parent returns to work.

PERSONAL EXAMPLE: Brushing or combing of the Hair when mom did it, it was always done away from the face and you never really realized how much you loss until you did it yourself-shock!

\section{DEFINE GRIEF}

Three (3) Kinds of Grief
Acute
Unresolved Grief
Good Grief

CHANGE

NEW NORMAL 


\section{EXPERIENCING GRIEF}

by Joyce Hatchett

From the moment of birth, we begin to experience loss and grief. Being evacuated from the warm and nurturing womb and thrust out into a cold and foreign environment is probably our first experience with loss - and what a loss! There are times we wish we could somehow climb back into the safety of the womb.

We experience losses all through childhood: We loose our bottles or breast feeding; our teeth; our moms and dads (when they return to work)

\section{LOSS}

A. LOSS is when something or someone is no longer a physical part of our lives or existence and it hurt.

\section{GRIEF}

A. GRIEF is that which we feel inside ourselves. MOURNING is that outward expression of those inside feelings. It comes natural to everyone who breaths. It is inevitable! You cannot live without experiencing grief in a thousand different ways.

\section{B. KINDS OF GRIEF}

1. Acute Grief - Somatic distress, preoccupation with the image of the deceased, guilt, hostile reactions, loss of patterns of conduct.

2. Unresolved Grief - Not allowing one's self to enter the grieving process. The person has to be helped to "extricate self from the bondage of the deceased and find new patterns of reward interactions."

3. Good Grief - With a basic philosophy that by establishing a relationship with God they can face any earthly loss with the knowledge that they have still have not lost everything. They still have God on whom to rely. It makes an amazing difference in the quality of the grief experience. It actually can become Good Grief.

C. CHANGE - We can never be who we were before our special person died because the death of that person changes us, changes our definition of who we are.

D. A NEW NORMAL - Learning to live with our losses and striving to find a "new normal" - whatever that may mean for each of us. 


\section{EMOTIONS (SHOW AND TELL)}

FEEL THESE EMOTIONS

FACIAL MUSCLES

HOLD FOR TWO MINUTES

SEE THESE EMOTIONS

LOOK IN THE MIRROR

SEE WHAT OTHERS SEE

\section{FEELING WORDS}

\section{WORDS THAT SAY THE SAME THING}

HAPPY or vivacious SAD or melancholy ANGRY or irritated

DOUBTFUL or pessimistic EAGER or anxious HURT or distressed

FEARLESS or courageous INTERESTED or intrigued

PHYSICAL or alive AFFECTIONATE or passionate 


\section{$e^{M @ 10} \mathbb{N}$}

\begin{tabular}{|c|c|c|c|c|c|c|}
\hline aggressive & $\begin{array}{c}\infty \\
\text { alienaled }\end{array}$ & $\underbrace{6450}_{\text {angry }}$ & $\begin{array}{c}0,0 \\
\text { annoyed } \\
\end{array}$ & $(\underbrace{((\mathcal{O})}_{\text {anxious }})$ & $\stackrel{20}{r_{0}^{2}}$ & $\begin{array}{c}00 \\
\text { bashlul }\end{array}$ \\
\hline bored & Eaulious & conlident & conlused & Curious & $\begin{array}{c}\text { Dos } \\
\text { depressed }\end{array}$ & of \\
\hline disappointed & discouraged & isgusted & embarrassed & enthusiaslic & 遂 & ecstalic \\
\hline exciled & $\begin{array}{l}\text { AlE } \\
\text { exhausled }\end{array}$ & learlul & $\begin{array}{c}4 . \odot \\
0 \\
\text { Irightened } \\
\end{array}$ & $\begin{array}{l}200 \\
\text { ifusiraled }\end{array}$ & guilly & hapoy \\
\hline $\begin{array}{c}0 \\
\text { helpless } \\
\end{array}$ & hopelul & hostile & humilialed & hurt & hysterical & $\Leftrightarrow$ \\
\hline$\underbrace{2000}_{\text {interested }}$ & jealous & 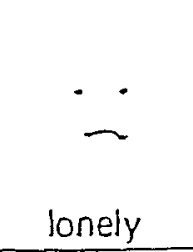 & $\begin{array}{l}\text { fyot } \\
\text { loved }\end{array}$ & loveslruck & mischievous & (5) \\
\hline negalive & $\hat{00}$ & $\overbrace{\text { pained }}^{\theta p}$ & $\underbrace{}_{\text {cnso }} 0^{1)}$ & peacelul & proud & $\underbrace{-18}_{\text {puzpled }}$ \\
\hline $\bar{Q}_{\text {regrellul }}$ & $\underbrace{}_{0} 0_{b})^{\circ}$ & sad & $\overbrace{\text { satisfied }}^{Q_{1} \theta}$ & $\begin{array}{c}\text { to } \\
\text { shocked }\end{array}$ & shy & sorry \\
\hline$\underbrace{A \hat{A n}}_{\text {slubborn }}$ & sure & 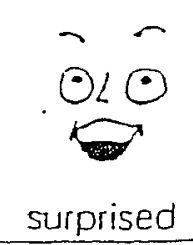 & suspicips & $\begin{array}{c}0 \bar{O} \\
\overline{-} \\
\text { thoughilul }\end{array}$ & undecided & $\begin{array}{c}-i= \\
- \\
\text { wilhdrawn }\end{array}$ \\
\hline
\end{tabular}


FEELING WORDS

\begin{tabular}{|c|c|c|c|c|}
\hline HAPPY & $\underline{S A D}$ & ANCRY & DOUB TFUL & MISCELLANEOUS \\
\hline bouyanc & ashamed & annoyed & defeated & boted \\
\hline brisk & blah & awkward & dubious & c rue 1 \\
\hline $\mathrm{calm}$ & choked up & belligerent & evasive & distant \\
\hline carefree & compassionate & bewildered & distruscful & envious \\
\hline cheerful & concerned & bitter & helpless & humb le \\
\hline comforcable & disappoinced & boiling & hesitant & jealous \\
\hline complacent & disconcenced & confused & hopeless & mixed-up \\
\hline contented & discouraged & cross & indecisive & preoccupied \\
\hline ecstatic & dismal. & enraged & perplexed & corn \\
\hline e laced & dreadful & frustrated & pessimistic & \\
\hline enthusiastic & dreary & fuming & powerless & \\
\hline exciced. & dull & Eurious & quescioning & AFKAID \\
\hline exhilirared & embarrassed & grumpy & skeptical & \\
\hline festive & flat & indignant & suspicious & a larmed \\
\hline generous & gloomy & inflamed & unbelieving & anxious \\
\hline glad & heavy-hearced & infuriated & uncertain & appal led \\
\hline graceful & ill at ease & irace & wavering. & apprehensive \\
\hline hilarious & in the dumps & irritated & & awe d \\
\hline inspired & low & offended & PHYSICAL & cautious \\
\hline jolly & me lancholy & provoked & & cowardly \\
\hline joyous & moody & resent ful & alive & dependent \\
\hline jubi $\mathrm{L} \operatorname{Lan} t$ & mournful & stubborn & breathless & dismayed \\
\hline lighthearted & out of sorts & sulky & empty & doub c [ul \\
\hline inerry & quiec & sullen & feiscy & Fearful \\
\hline optimiscic & somber & wrachEul & hollow & Eidgety \\
\hline peaceEul & sorrow ful & & immobilized & Frighrened \\
\hline play rul & sulky & FEARLESS & nauseated & gucless \\
\hline pleased & sullen & & paralyzed & hesitanc \\
\hline relaxed & sympachetic & bold & repulsed & horrified \\
\hline restful & shame ful & brave & sluggish & hyscerical \\
\hline sacisfied & unls appy & confident & stietched & impatient \\
\hline serene & useless & courageous & strong & insecure \\
\hline surpitised & worchless & daring. & sweacy & ncivous \\
\hline sparkling & & determined & taut & panicky \\
\hline spicited & HURT & encouraged & cense & pectified \\
\hline thrilled & & hardy & cired & pressured \\
\hline vivacious & aching & heroic & uptight & shaky \\
\hline & afflicted & impulsive & we ak & shocked \\
\hline EACER & $\operatorname{cold}$ & independen $\mathrm{c}$ & we ary & scared \\
\hline & crushed & loyal & & suspicious \\
\hline anxious & despair & proud & AFFECTIONATE & cerrified \\
\hline atdent & distressed & reassured & appealing & chreatened \\
\hline avid & heartbroken & secure & close & cimid \\
\hline desicous & injured & & loving & cragic \\
\hline enchusiastic & isolaced & INTERESTED & passionace & wishy-wasliy \\
\hline exciced & lone ly. & & seductive & worried \\
\hline incent & of Íended & absorbed & sexy & \\
\hline keen earnes c & pained. & concerned & cender & \\
\hline proud & pachecic & curious & warnı & \\
\hline zealous & suffering & engrossed & & \\
\hline & $\begin{array}{l}\text { corcured } \\
\text { worcied }\end{array}$ & $\begin{array}{l}\text { exciced } \\
\text { fascinaced }\end{array}$ & & \\
\hline & & incrigued & & \\
\hline
\end{tabular}




\section{PART 1: A LOOK AT PROBLEMS IN GRIEF}

\section{ANGER}

ANGER is a recurring experience that hits you for no reason at the strangest places. It is unpredictable.

\section{ANGER}

- ADMIT IT. Anger is no cause for shame. It is a legitimate buman emotion.

- ANALYZE IT. Slow down long enough to figure out exactly what is the cause of the anger.

- ACT IT OUT IN A CONSTRUCTIVE WAY. Physical exercise is most frequently mentioned as a good way of getting rid of anger.

- ABANDON IT. Once you get it out in the open, don't put it back on your shoulders again. Talk it out with others help. Praying about it helps also.

\section{GUILT}

Take time to analyze the guilt. If there is cause for feeling guilty, ask God for forgiveness. Talking it out helps to weaken the impact of the unreal guilt. Guilt usually disappears in a few months.

\section{ENSTRANGEMENT}

Once the intense socialization of the funeral is over, piople seem to avoid the survivors for many reasons. This is the time when many people need to talk, but the avoidance of friends causes the griei-suriken to withdraw. They feel estranged. They may refuse to leave the nouse. Some people say, "I'm just not ready to go out among people yet."

It is suggested that you go out on brief errands at first. Extend the trips gradually to take up more time and to include more people contact. 


\section{ADAPTING TO LOSS}

by Joyce Hatchett

GRIEVING is work. The task is to acknowledge the full measure of pain you feel, whether by crying, talking with others, or spending hours in quiet contemplation.

- It is natural to have flares of -- ANGER, FEELINGS OF DEPENDENCY, OR A SENSE THAT YOU ARE FRAGILE AND NOT IN CONTROL.

You are also likely to need strong support in this endeavor. Don't be afraid to unburden yourself to friends and family, yet don't be surprised if their response is inadequate.

Loss is threatening to others, especially in our culture, and it's natural to shy away from the aggrieved. In our society that places high premium on keeping a stiff upper lip and getting back to business, it is often difficult to allow yourself to play out the full range of emotions you feel. You may find that a psychotherapist is the best person to guide you.

* It is easy to neglect one's self during this period. Try to muster up the energy to eat regular, balanced meals; they can be small if you have little appetite. Get some exercise!

As you consolidate your grief, you will begin to realize that although life may be different, it has new meaning. You can draw upon experiences and memories of life before your loss and use the strength you developed to surviving it to shape your future. 


\section{GRIEF TIME SCHEDULE by Joyce Hatchett}

After a major loss a person must give himself/herself permission to grieve. Ultimately we need to experience "psychological amputation" from the relationship as it was during the time the person was alive. This is called "saying goodbye."

Saying goodbye, IS NOT saying goodbye to the memories, but to a relationship. This IS NOT a single event. It is done in bits and pieces. Because you give yourself permission to say goodbye the hurt IS NOT so intense.

Moving out into life again will be a mixture of joy and sorrow, but saying goodbye in bits and pieces will bring you to the place where you will give yourself permission to stop grieving.

Grief is the highest tribute to love, but prolonged beyond a reasonable point, it can turn into a monument to self-pity and self dramatization.

It is perfectly normal for it to take a year or two to permit yourself to stop grieving, but some people decide to grieve the rest of their lives. This can be true of people who DO NOT have a very strong support system. Talking about your loss gains a few people who will listen, but the fear is if they stop grieving the sympathetic people will be lost. In your fear you DO NOT perceive that the constant recital of the morbid details will make the friendships vanish even sooner.

People who grieve early and intensely have a greater chance of moving out of acute grief easily. Once out of acute grief a person is better able to strengthen his/her support system. It removes the chance of wasting precious life in unnecessary mourning time. 


\section{LETTING GO}

by Joyce M. Hatchett

Most of what we read about grief and loss assumes that our relationships with those we have lost are perfect. In a fantasy world that would be true. We, however, ive in a world of reality and know that our relationships are sometimes less than perfect.

We're human and so are those who share our lives. And, humans make mistakes, make wrong choices, say things they shouldn't, and live life on their own terms.

\section{Unresolved Issues}

Some times when we lose a loved one there are unresolved issues that we must work through.

We may have feelings of anger, hurt, frustration, or pain that are deeply rooted in our pasts.

We may regret things we have said or done, or those we neglected to do.

We may feel abandoned by our lost loved-one. We may have feelings we can't define except to say that they cause us pain.

These feeiings can be harmful to us, not only in resolving issues with the lost loved-one, but in our future relationships as well.

It's imporian: to understand where these feelings come from and realize that there is notining $w=$ can do to change the past. And, there is nothing we can do to change ot:iers Either. What we can do is to change ourselves and the way we think about our past, others in our life, and our futures. 


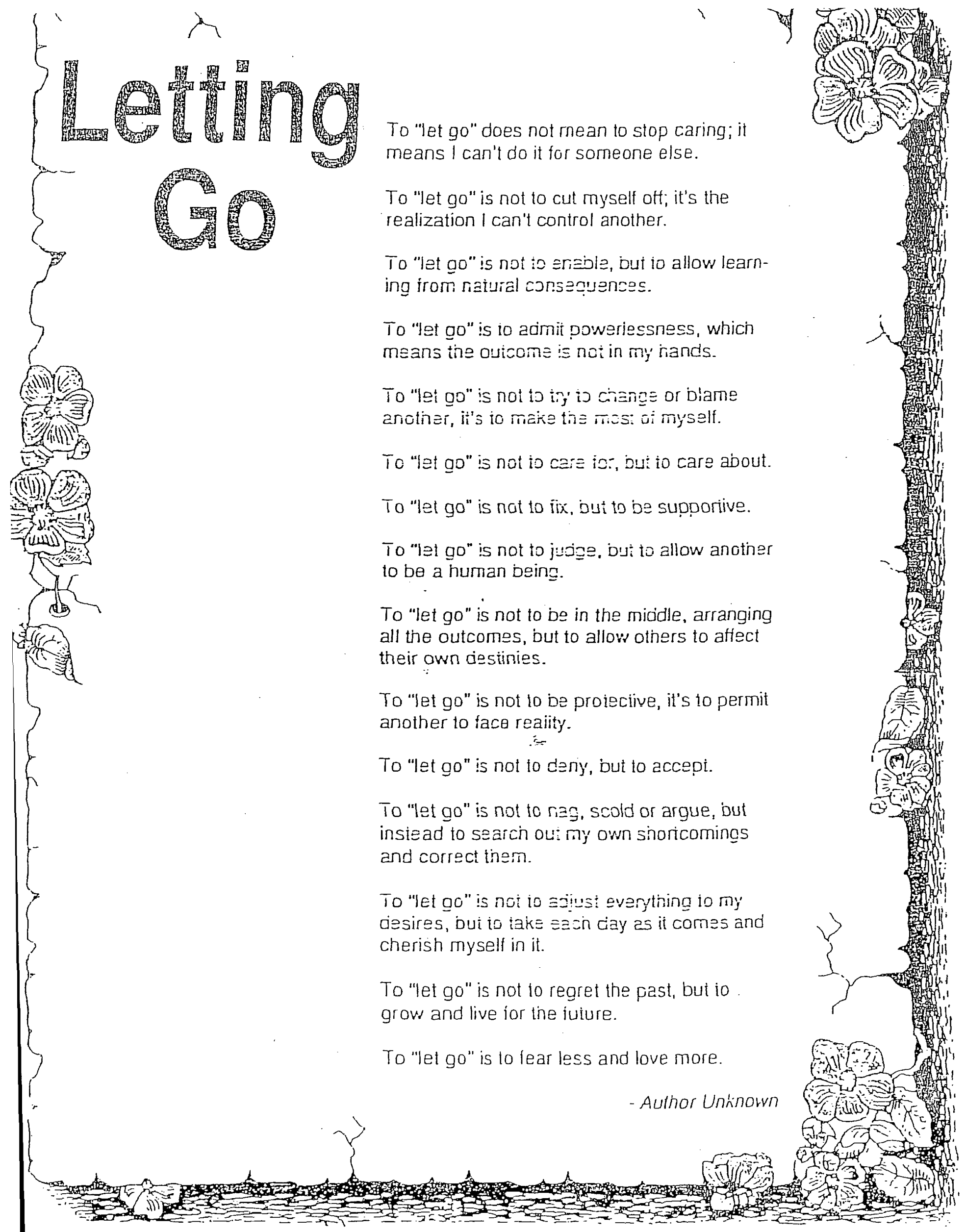




\section{PART II: A LOOK AT PROBLEMS IN GRIEF}

\section{RUNNING:}

by Joyce Hatchett

Most people who run are afraid of experiencing the pain. Facing the pain mellows the pain and removes the reason for running. Talk about your losses with a trusted friend or with a group or a counselor.

\section{PREMATURE REENTRY INTO THE STREAM OF LIFE:}

Premature reentry into the stream of life is caused by societal pressure to get back to normal. If a person bas to force him/herself to do every little activity, it could mean that insufficient grieving was done.

It is suggested that you go back to work or school gradually. Going to the boss or teacher and telling them that your performance will be subnormal for a few weeks gives grievers a chance to attend to the adjustment.

\section{SHRINE BUILDING:}

Not touching the missing person's room or belongings is sometimes seen as respect for the person who died. It is usually a result of refusal to believe the death occurred. It can also be a strong desire to avoid pain.

\section{EXPECTING TOO MUCH!}

There is no one person who can meet all of our emotional needs. Still, some grieving persons expect more emotional support from one person than that person can give. This can drive people away when you need them most.

\section{PERPETUATION OF GRIEF:}

There are secondary benefits in grief. The warmin and closeness shown to people in early grief is often a cherished but seldom realized experience. It is possible to want to keep grief alive so that the cioseness and warmth is perpetuated.

\section{LOSS OF IDENTITY:}

This is a loss within a loss. Grieving the loss of a role accompanies the loss of a person. 


\section{THINGS TO DO}

by Joyce Hatchett

\section{Here are some things to do to let go of anger and past hurts.}

* Make a List - a list of the things in your past that have made you angry and still cause pain. (pause) Reflect on the list and realize that those things cannot happen again.

* Change Your Thinking - Change the way you think about others' actions. (pause) Realize there were reasons for their choices even if you don't understand or know what those reasons were.

* Realize - The only person who does not make mistakes is the one who does nothing. (pause) Say to yourself, "I forgive the mistakes of others and refuse to let regret rob me of my happiness."

* Consciously Forgive - Forgive yourself for any transgressions or omissions. (pause) Ask our loved-one(s) for forgiveness.

* Remember - Forgiveness is something you do for yourself. (pause) Forgiveness gives you peace of mind now, in the present and in the future.

* Make a Conscious Commitment - Release others' power over your life. (pause) Say to yourself, "I may have felt hurt, anger or regret in the past, but today I refuse to allow those memories to continue hurting me."

Accept - The person I have lost was not the person I wanted them to be. (pause) They were completely themselves, and that is one of the many reasons I loved them so much.

* Understand - It's okay to love someone even if they were not perfect.

- Know - There is nothing in my past that can hurt me unless I allow it to. (pause) Say to yourself, "I am free."

* Realize - The person I have lost loved me the only way they knew how. (pause) Say to yourself, "I can appreciate them for that."

* Know - It is OK to express my true feelings and it is not disloyal to do so.

* Accept - The past is over. (pause) My future is my responsibility. Say to yourself, "I am committed to making it as good as it can be."

Know - If I continue to have trouble with unresolved issues, I should consider professional therapy immediately. 


\section{ITSY BITSY CRITICISM COMMITTEE REPORTING FORM \\ by Joyce M. Hatchett}

This is mental exercise where a person calls to order the Itsy Bitsy Criticism Committee (IBCC) at an appointed time during the day for 5 MINUTES ONLY. Then adjourn the committee and set another appointment for the same time the next day. This will allow for 23 hours and 55 minutes of freedom to do whatever makes you happy. Preferably this meeting will take place early in the morning. CONSISTENCY is important, same time everyday Mark your personal calendar(s).

If the committee tries to convene at anytime during the rest of the day, remind yourself of the appointed time. .

First Appointment:

\begin{tabular}{|l|l|l|}
\hline DAY OF THE WEEK & $\begin{array}{l}\text { TIME THE IBCC IS } \\
\text { CALLED TO ORDER }\end{array}$ & $\begin{array}{l}\text { TIME THE IBCC IS } \\
\text { ADJOURNED/AND } \\
\text { SIGNATURE }\end{array}$ \\
\hline SUNDAY & & \\
\hline MONDAY & & \\
\hline TUESDAY & & \\
\hline WEDNESDAY & & \\
\hline THURSDAY & & \\
\hline FRIDAY & & \\
\hline SATURDAY & & \\
\hline $\begin{array}{l}\text { When this week is } \\
\text { completed, CELEBRATE! }\end{array}$ & & \\
\hline
\end{tabular}

Second Appointment:

\begin{tabular}{|l|l|l|}
\hline DAY OF THE WEEK & $\begin{array}{l}\text { TINE THE IBCC IS } \\
\text { CALLED TO ORDER }\end{array}$ & $\begin{array}{l}\text { TIME THE IBCC IS } \\
\text { ADJOURNED/AND } \\
\text { SIGNATURE }\end{array}$ \\
\hline SUNDAY & & \\
\hline MONDAY & & \\
\hline TUESDAY & & \\
\hline WEDNESDAY & & \\
\hline THURSDAY & & \\
\hline FRIDAY & & \\
\hline SATURDAY & & \\
\hline $\begin{array}{l}\text { When this week is } \\
\text { completed, CELEBRATE! }\end{array}$ & & \\
\hline
\end{tabular}




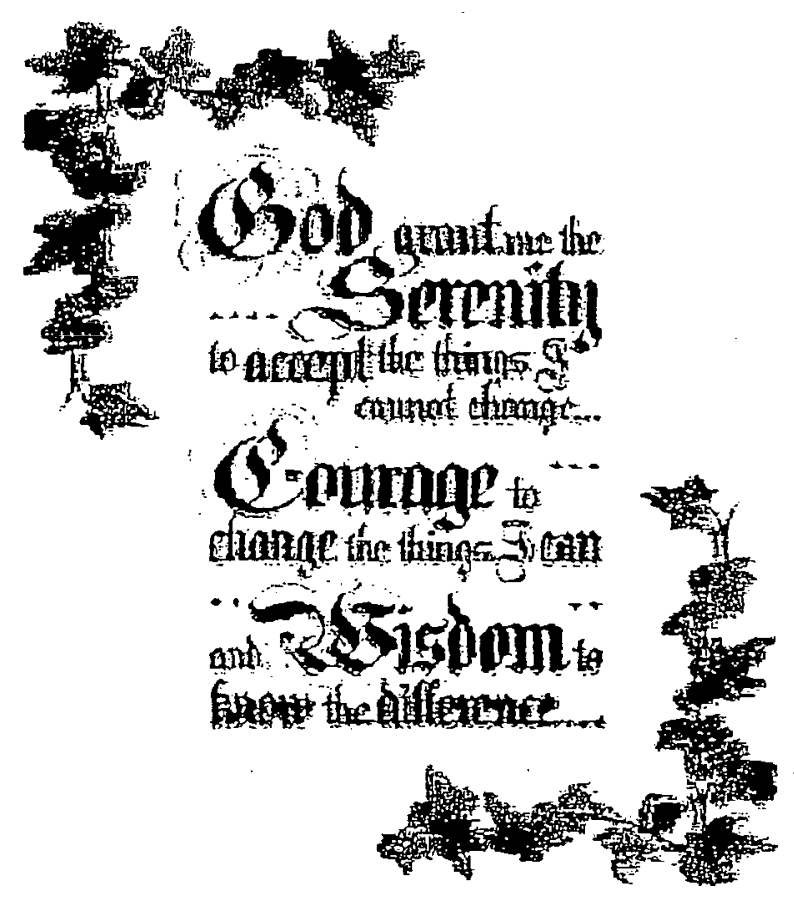

Living one day at a time, Enjoying one moment at a time, Accepting hardship as the pathway to peace.

Taking, as He did, this sinful world as it is, not as I would have it. Trusting that He will make all things right if I surrender to His will.

That I may be reasonably happy in this life, And supremely happy with Him forever in the next Amen.

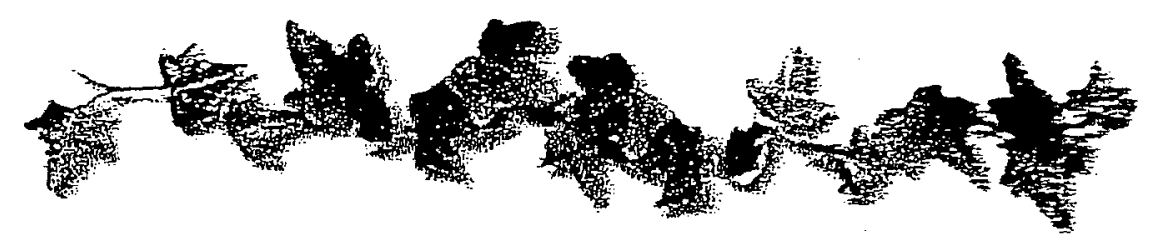

\section{A Brief History of the Serenity Prayer}

There is no shortage of theories as to who wrote the Serenity Prayer. There are unending twists \& turns in the quest to uncover the original author. For every bit of research that we've uncovered, there has been more research to refute it. 


\section{SESSION 3}

\section{STAGES OF DEATH, STAGES OF GRIEF AND STRESS MANAGEMENT}

Stages of Death (Elisabeth Kubler-Ross)

Stages of Grief (Granger Westberg)

Grief Model by Theorist.

Stress Management and Relaxation.

Breath Prayer

Exercise: Be Good To Yourself/Breath Prayer 


\section{STAGES OF GRIEF}

Anticipator Loss/Death

Elizabeth Kubler-Ross

\section{ANGER DEPRESSION BARGAINING}

ACCEPTANCE

DENLAL 
Elisaleth Kibler Ross.

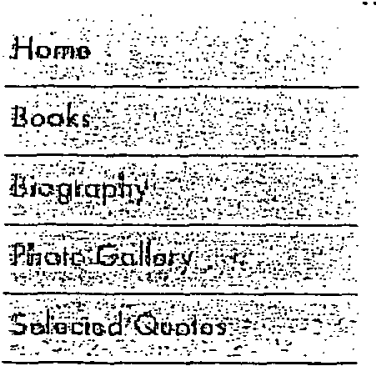

Atout Griat E Ecresinme:

Professional Coregines. $\frac{\text { Hospelosto }}{\text { Hos }}$ Hospse Lealo Supportad Orgonizations inemanome! Groups Nendetret

Scantae Nito

GuEsiook

Enail sist

\section{About Grief and Bereavement}

Grief is a natural process to death and dying. It is not pathological in nature, but rather, is a necessary response to helping heal from the overwhelming sense of loss when a loved one dies.

It is important to understand grief as part of the human experience. If you are grieving, some things you can do to help yourself include:

\section{-Attending support groups in your area}

Many communities have secular and faith based support groups focused on spousal, parental, and child death.

\section{-Therapy with a psychologist or other qualified mental health} professional

Tnerapy can be helpful in many ways especially when combined with a support group.

\section{-Journaling \\ Writing is a catharsis for many!}

\section{-Eating well}

It is important to eat healthy foods and take supplements.

\section{-Exercise}

Take walks or work out: jog, aerobics or a spring-cleaning week will do as well. Physical exertion is a great stress reliever and may afford you some iime alone to gather your thoughts in the process.

\section{-Get enough rest}

Give yourself plenty of time to rest. Grief drains your ernoiional batiery anc you will need to recharge more often. If you simply don't want to get out of bed in those early stages of grief, then don't!

\section{-Reading and learning about death-related grief responses}

Knowledge heips people regain a sense of control over their experiences and environment and helps reduce feelings of vulnerability.

-For some, seeking solace in the faith community

It can be helpful for some to seek the wisdom and comiort that cinurcines. synagogues, temples, mosques, and other places of worship provins.

\section{-Seek comforting rituals}

This include funerals and memorial services, planting gardens and ir $=25$. donating to a cause, and other comforting and culturally appropriate ritiai

-Allow emotions
Tears can be healing.

-Avoid major changes in residence, jobs, or marital status Major changes can be too burdensome during grief. Wait for about one year after the death of a loved one before making any major changes. 
One of the most difficult losses to endure is the death of a child. One of my books, "On Children and Death," deals with this topic in a very helpful way. I highly recommend this book for bereaved parents.

Parents experiencing the death of a child can find great comfort in connecting with others who have also gone through that tragedy.

There are several support groups which provide this solace to families:

The MISS Foundation helps families experiencing stillbirth, infant, and toddler death and also provides thanatological training for caregivers and public policy analyses.

The Compassionate Friends is a broad support organization .

Befrienders is an organization specinic to suicide prevention and support.

Parents of Murdered Children focuses on these suffering from their child's death as a result of homicide.

Some type of counseling or therapy may a!so be helpiul to families experiencing child death.

It is important to realize that children moum, 100. Children may nol express their feelings of loss in the same vay as acults. Here are some helpiul resources for grieving children (Adobe Reader Required to View):

Helpful books for the Grieving Child:

- What Color is Death, Daddy?

An interactive book for children ages 3-7

- The Kaleidoscope of Grief: When Crildren Experience

Death

An interaciive book for Children ages 7 and up

- Kaieidoscope book En Español

- Helping Grieving Children

A helpiul brochures to help others understand how to help chiloren Supporting the bereaved is a community responsibilty. Together, we can make a difierence in the worid!

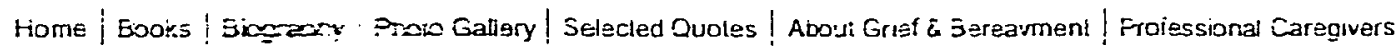

Hospize Lozaio: : J

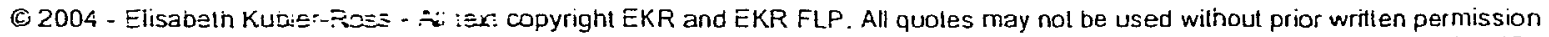
(See contact me page). Al! srotas scouright by Ken Ross and may not be used withoul prior writlen permission of pholographer (See contact me page) 
TEN (10) STAGES OF GRIEF

(Granger E. Westberg, "Good Grief," Philadelphia, PA: Harper\& Row, Inc, 1962, 21-63.)

STAGE 1: $\quad$ SHOCK

STAGE 2: EMOTION

STAGE 3:

DEPRESSED AND VERY LONELY

STAGE 4:

PHYSICAL SYMTOMS OF DISTRESS

STAGE 5

PANICKY

STAGE Ó:

SENSE OF GULT ABOUT THE LOSS

STAGE 7:

ANGER AND RESENTMENT

STAGE 8:

RESIST RETURNING.

STAGE 9:

HOPE

STAGE 10:

AFFIRM REALITY 


\section{Grief Model by Theorist \\ Phases of Grief}

In an attempt to understand and deiineate the various processes associated with grief, researchers have devised a number of models that present these processes within a framework involving a theory of stages. Some modeis posulate inres stages, otners seven or ten. To outline the stages of grief work in this manner seems to suggest a iinea: progression from the firs! stage, through the second, and so on, until the process has been completed. Although this notion might provide comfort to those who wish to evaluate a survivor's journey toward reintegrarion after loss, it is important to place these theories in their intended coniex:

\begin{tabular}{|c|c|c|c|c|c|c|c|c|c|}
\hline Tivarist & \multicolumn{9}{|c|}{ 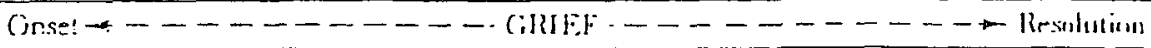 } \\
\hline Strt:- & \multicolumn{2}{|r|}{ Simst: } & \multicolumn{4}{|c|}{ intens: grief wast } & \multicolumn{3}{|c|}{ 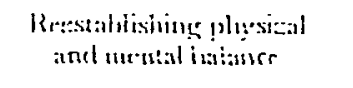 } \\
\hline Ka:araugi: & Sime: & Detsormanzains & $\begin{array}{l}\text { Vis:miii: } \\
\text { =nustiuss }\end{array}$ & Cini & & $\begin{array}{l}\text { Luss :und } \\
\text { loneliness }\end{array}$ & Rel & & Reesiallisinumens \\
\hline 1:ล:3i:a=! & \multicolumn{2}{|c|}{$\begin{array}{c}\text { Sim-i, num:n:=-s. } \\
\text { aisisy:i:=5 }\end{array}$} & S-:aratum & & \multicolumn{3}{|c|}{ 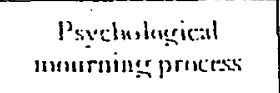 } & \multicolumn{2}{|r|}{ Rrintraratiun } \\
\hline $\begin{array}{c}\text { Weizman and } \\
\text { Kamn }\end{array}$ & \multicolumn{2}{|c|}{$\begin{array}{c}\text { Shack, ciisiseiief, } \\
\text { cienial }\end{array}$} & loings & \multicolumn{3}{|c|}{ Anesr } & \multicolumn{2}{|c|}{ Sirlness } & Intrgracina \\
\hline Worcien & \multicolumn{4}{|c|}{ Accepsing the resiity } & \multicolumn{3}{|c|}{ 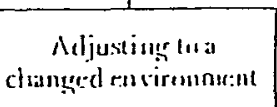 } & & 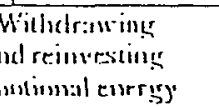 \\
\hline
\end{tabular}

The theories concerning stages of grieî represent an effor to specify various aspects of a process that occurs in highly individualistic ways. Thus, although models of grief can be very helpful in increasing our understanding, we should not try to superimpose a particular structure on the actual grief experience of a particular survivor.

Lynne Ann DeSpelder and Albert Lee Strickiand. The Last Dance: Encountering Death and Dying. (Palo Alo, CA: Mayrield Puin. Co., 1987, 212. 


\section{STRESS MANAGEMENT \\ AND RELAXATION}

by Joyce $M$. Hatchett

Grief tends to tighten up the muscles. This in turn impairs deep breathing, fidgety behavior and nervousness results. A sense of unrest and boredom are often reported due mainly to the unrelenting muscle tension associated with grief. Actual muscle soreness results from this tension.

Grief centers a person's focus on self. This is normal, but to keep the focus on self for too long can tie a person up in tension knots.

- Begin giving out to others as soon as possible. It is a good way to ease the tension.

- Show gratitude everyday. A good place to start is the many great people who showed kindness during your loss.

- Say "I LOVE YOU" to somebody.

- A smile for somebody helps.

- Be forgiving toward people who wronged you.

- Talk courage and hope.

- Go to a quiet spot where you can ask God for his peace that surpasses human understanding.

- Let your trust in God grow.

Tension is the opposite of relaxation. The body consumes more energy when tense. During relaxation, the body restores energy, maintains health, and maintains youth. One is better able to think, one can work better, the disposition improves, one is happier.

\section{PRE-DISPOSTION FACTORS}

A. There must be a desire to relax.

B. General Factors that aid relaxation:

1. Warm Feet

2. Light evening meal

3. Avoiding intense mental activity at night or heated discussions 


\section{RELAXATION ROUTINE}

by Joyce M. Hatchett

A five (5) minute active warm-up of active exercises to improve the flexibility of the body will lessen stress. Lack of flexibility adds stress to the muscles and joints.

Active Flexibility Exercises

1. KNEE LIFT - Alternate legs. Bring the knee up to the chest, pull up with the arms; return to starting position. Repeat with the opposite leg (ten times each leg, totaling 20 times).

2. SIDE NIP IN - (Lateral Bending) One hand should be allowed to follow down the outside seam of the trouser as the body is bent to the side, while the other arm is curved up over the head as if reaching way beyond the body. Repeat the bending to the opposite side of the body (each side should be done 10 times, totaling 20 times).

3. STRETCHER - Touching the toes with the fingers. The knees need not be kept straight. Reach arms straight up over the head and then down to the toes (ten times).

4. PARTIAL SIT-UP - Lying on the back, arms straight out in front of you, raise the head and shoulders up off the floor or bed. DO NOT attempt to come to the sitting position (10 times).

5. PARTIAL PUSH-UP - On hands and knees, bend arms, permit face to come down between hands. Push up and back, rocking back on knees to sit back on feet. (DO THIS ONLY FIVE (5) TIMES)

If you are in good health, with no heart problem, run in place. When you become a bit breathless, stop and rest. Work gradually to 200 paces.

These exercises seem easy, but don't try to add to them because they seem easy. 
$\because \quad$ Breath Prayer ${ }^{1}$

Breath Prayer is for that special "something." This prayer is nothing we are taught. Rather it is one we discover for ourselves. It lies within us like a tiny seed that, when nurtured, will grow and flower into a new closeness with God. Here are five easy steps to follow:

- Step One - Sit, kneel or lie in as comfortable a position as possible. Then be calm and quiet. Close your eyes and remind yourself that God loves you and that you are in God's presence. Recall al favorite passage from Scripture that places you in a restful frame of mind. (e.g. "Be still, and know that I am God." Psalm 46:10)

- Step Two - As you keep your eves ciosed, imagine that God is calling you by name. Listen carerully and bear God asking vol: : , what do you want?"

- Step Three - Answer God with whatever comes honestly from your heart. Your answer may be 2 single word, such as peace or love o: forgiveness. Your answer may instead be a phrase or brief sentence, such 25 "I want of feel pour forgiveness" or "I want 10 understand your love" or "I want to be with you" Whatever your response is, it becomes the hearl of your praver.

- Step Four - Choose your javorite narne ior Goc. (Choices people commonly make include: God, Jesus, Christ, Lord, Spirit, Shepherd, and Creator.)

- Step Five - Combine your name for Goủ utin your answer to God's question "What do you want?" and you have your praye:. For exampie:

\begin{tabular}{|c|c|l|}
\hline What I want & Name I call God & Possible Prayer \\
\hline Peace & God & $\begin{array}{l}\text { Let me know your peace, O } \\
\text { God. }\end{array}$ \\
\hline Love & Jesus & Jesus, let me feel your love. \\
\hline Rest & Shepherd & $\begin{array}{l}\text { My Shepherd, ler me rest in } \\
\text { thee }\end{array}$ \\
\hline
\end{tabular}

What do you do if several ideas occur? You need to eliminate or combine ideas until you have focused your prayer. You may "want" many things. But if you think careúlly, you can natrow your wants to a specific need that you feel is as basic to your spiritual well-being as water is $t$ life. Thus the question you need to ask yourself is: W'lat do I want that will make me feel most whole? Once you achieve a feeling of wholeness, PEACE OF MIND and HEART will follow.

When you have gotten to the core of your needs, search for words that give it expression. Then work with the worids until you have a praver oi six to eight syllables. The words should fiow smoothly' whetner spoken aloud or expressec silentiy as neari-inougnts.

Your prayer may be most thythmic when God's name is placed at the beginning, but ury it at the end as well. One way will feel better than another. When your prayer seems night for you, write it down (Journaling). Then use it often throughout the day. Whenever you think of i!, (immediately) repeat the prayer several times. You can whisper it. You can say it aloud. You can think: it. In time, your breath prayer will become as natural as breathing. Even when you are not consciousiy prayer, the words will play in your heart like a refrain from a favorite song.

'Ron DelBene, Mary Montgomery', and Herb Montgomery. W'hen I'm Alone: Thoughts and Praver that Comfort (Nashville, TN: The Upper Room, 1988), 7-9. 


\section{Opening to God}

The purpose of this prayer is to slow yourself down, and be aware that God is with you.

Sitting comfortably, place your hands on your lap with palms up, to symbolize welcoming and receiving. Become aware of the openness of your hands, and the air at your fingertips, on your patms. Enjoy the relaxation.

Air is a word in the Bible that also means Spirit, since air, like God, is invisible and potentially powerful, and gives us life. Air symbolizes God's presence. As you sit, let the opening of your palms be an invitation to God to be with you, and the air a reminder that God is there.

Sit in this way for as long as you find it is a prayer (or slip it in briefly during the day as a quick reminder.)

\section{Breath Prayer}

The purpose of this prayer is to help you use your relaxed breathing as a way of bringing you calm and strength, letting go of your tensions, and breathing in the help of God.

In a comfortable position, take deep breaths, as if your were breathing from your toes, and let that breath be carried up through your entire body. Feel the relaxation it brings.

As you breathe in, imagine yourself receiving peace, joy, wisdom, strength, whatever you need from God. You do not need to think in words. Just sense you are receiving what you need. Let your breathing in be a receiving from God.

As you breathe out, let it be a releasing, a letting go, an exhaling of whatever tensions or negative thoughts and feelings are not good for you. As you breathe out, release the problems which God knows are getting in the way of your being the person God, and you, would like to be. 
This can be used as a quick prayer, while doing something else, or during a more lengthy prayer time.

\section{Breathing with words}

The above breathing prayer may include words in your mind, as you breathe.

As you breathe in, you may think the words, "Come to me, God" or your own words with a similar meaning.

As you breathe our, you may think the vords, "Take away what's wrong, God" or your own vords with a similar meaning.

Or you may choose to be specific about what you sense you need to pray for yourself. As you breatine in you could think, "Wisdom, please", or another quality you need. As you breathe out you could think, "Remove my worry, please", or another quaiizy you sense is in the way.

Time out with Ted 2004 


\title{
SESSION 4
}

\section{PEACE OF MIND PART I: LONELINESS}

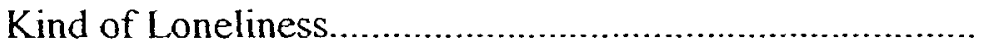 \\ State of Loneliness \\ Chronic Loneliness. \\ LIFE \\ God's Personalized Plan \\ Scripture Assurance
}

Exercise: God's Personalized Plan/Certainty of Christian Living 


\section{LONELINESS}

EMOTIONAL ISOLATION

"primary loneliness"

Brought about by the loss of a significant relationship in one's life through death or divorce.

Remedy: Finding another equally important relationship to fill the void.
SOCIAL ISOLATION

The deficiency of a social network or the "absence of a place in an accepting community.

Remedy: Access a network of social interactions, feelings dissipate. 


\section{State of Loneliness}

Here is a psychological definition for the State of Loneliness.

The state of loneliness, unlike solitude, is as a chronic, distressful mental condition whereby an individual feels estranged from peers and starved for the emotional Intimacy found in relationships.

Leigh Devereaux, "Loneliness," School of Psychology, Dotoral Program, Northcentral University

\section{COMPARISONS: Loneliness, Depression, and Grief}

Depression - may be a result irom loneliness. A lonely individual is driven to establish new relationships to aradicate the distressful state $5 /$ he endures. A depressed individual is unwiling to impose his/her unhappiness on others and thereiore remains in isolation.

Grief - could result from the death of a loved one or tive end oi some significant relationship that may have comprised the bulk of an individual's social interaction. Grief is the process of coming to terms with great loss while loneliness is simply a component of this procedure responding to the absence of the beloved.

\section{TYPES OF LONELINESS}

Loneliness of Social Isolation - involves the deficiency of a social network or "the absence of a place in an accepting community." The feelings in this form of loneliness revolve around boraojom, a lack oi focus, and a sense of being marginalized or rejected by peers. Those relationships include attachments, social integration, opportunity for nuriurance, reassurance of worth, reliable alliances and guidance.

Loneliness of Emotional Isolation - brought about by the lost of a significant relationship in one's life through jeatin or divorce. This loneliness type is often accompanied by nyper-alertiness and anxiety which makes the individual oversensitive to social cues leading them to misinterpret or exaggerate the intentions of others whether positive or negative. 


\section{CHRONIC LONELINESS}

Loneliness can be a very miserable state of being.

- Some people don't get over loneliness.

- Some people seem to be lonely no matter what their circumstance.

- Some people have a hard time making social contact. And when they do, they have an even harder time achieving intimacy.

When you haven' $I$ had a lot of positive stuff going in, it's hard to get positive stuff coming out. That is the dilemma of the chronically lonely. It can be a vicious circle. They usually haven't had warm relationships. That tends to isolate them. And the more isolated they are, the less likely they are to have warm relationships.

Have you been struggle with Chronic Loneliness?

YES NO

Are you feeling handicapped because you're shy and introverted? YES NO

Lonely people miss so many opportunities. Meaningful human contact keeps sliding right by them. WHY? Because they don't feel they have much to give. But when you've been touched by grace, you do have something to give. When the God of heaven began filling you up, you can afford to spill over a little bit.

Begin using those qualities for something positive. Use them to get to know the God who calls you by name intimately. You will find that even loneliness can be enriching if it chases you to God, clears your heart, and let your very best part shine through. 


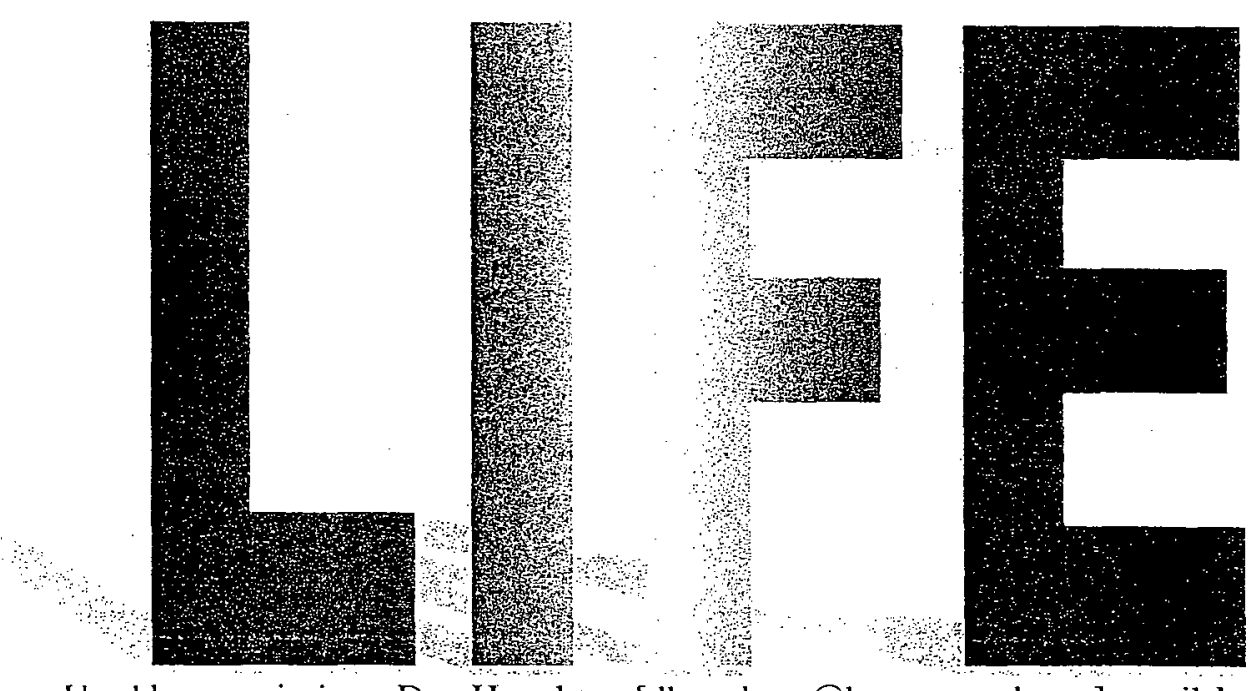

Used by permission: Dan Houghton [dhoughton@hartresearch.org] email June 14, 2005

\section{LUKE 15:3-6 \\ PARABLE}

What man of you, having a hundred sheep, if he loses one of them, does not leave the ninety-nine in the wilderness, and go after the one which is lost until he finds it? And when he has found it, he lays it on his shoulders, rejoicing.

And when he comes home, he calls together his friends and neighbors, saying to them, "Rejoice with me, for I have found my sheep which was lost!" 


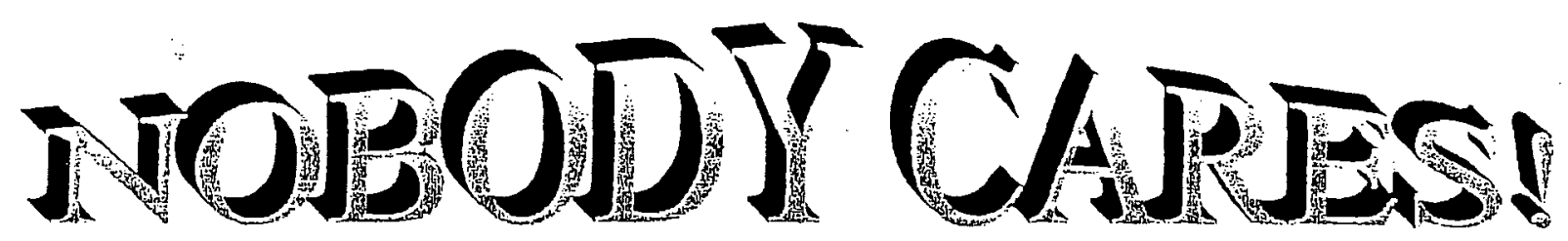

Used by permission: Dan Houghton[dhoughton@hartresearch.org] email June 14,2005.

\section{IS A DESPARATE CRY OF MEN AND WOMEN ON A LONELY PLANET}

Someone has said that the disease of the $21^{\text {st }}$ Century is Depression, caused by Low Self-Esteem.

$\therefore$ I am sitting 93 million miles from the sun on a rounded rock which is spinning at the rate of a thousand miles an hour and roaring through space to nobody knows where, to keep a rendezvous with nobody knows what, for nobody knows why. And all around me whole continents are drifting aimlessly over the planet. I'm sitting here on this spinning, speeding rock surrounded by four billion people, eight planets, one awesome lot of galaxies, hydrogen bombs enough to kill me thirty times over, and mountains of handguns and frozen food, and I am being sweep along in the whole galaxy's insane dash toward the far wall of the universe. And as I sit here, 93 million miles from the sun, I'm feeling absolutely miserable."

Russell Baker, a newspaper columnist

You may have heard of the contest held on a college campus to define the word life. The winning definition went this way:

"Life is the penalty for the crime of being born."

Jesus gives us a totally different picture. He reveals God's estimate of human worth in that timeless story of the Good Shepnerd. This parable tells us three things about human nature. Luke 15: 3-6.

1. The Shepherd was concerned about each individual sheep.

2. The Shepherd carefully observed that one was missing.

3. To the Shepherd, the sheep were not merely part of a heard of animals. He noted each one individually. 
Incredible Trade - We are His enemies, but He is our friend. As a Just man, he was condemned so that we, the Unjust, can be set free.

- Before we ask, His attitude is one of forgiveness.

- Before we repent, His Spirit impresses us with sorrow for sin.

- Before we confess, his mercy surrounds us, creating with us a desire to repent.

You need no longer battle with Guilt. Forgiveness is yours for the asking. REACH OUT AND RECEIVE IT TODAY!

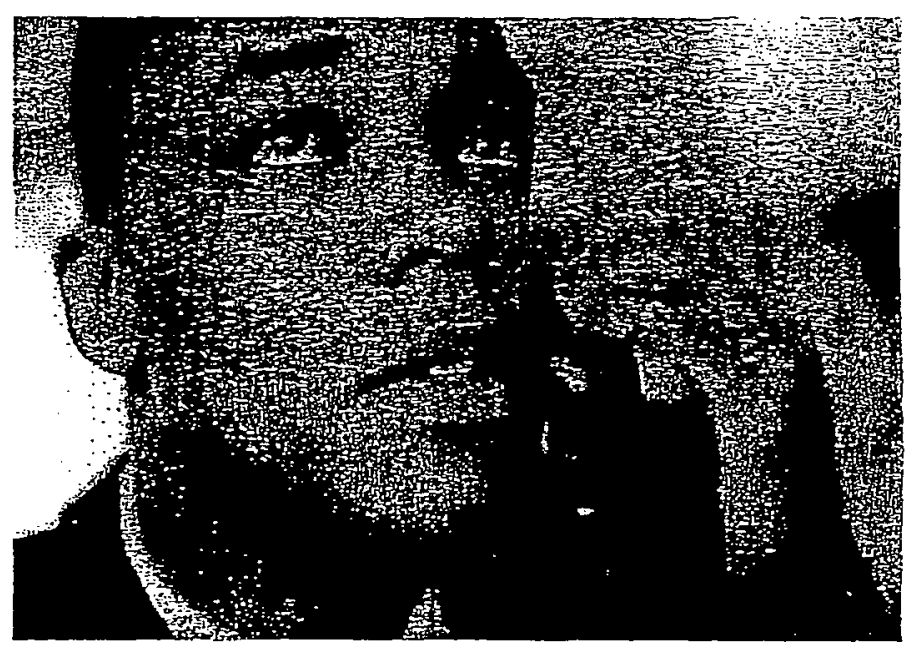

\section{LONELY NO LONGER}

If you are having difficult communicating with people, the best place to start remedying that is by communicating with God. WHY? Because God is so close to you - closer than you can imagine.

LISTEN to what the apostle Paul told some skeptical Greek philosophers in Athens, Acts 17:27, 28: "He is not far from each one of us; for in Him we live and move and have our being."

The Bible AFFIRMS that Jehovah is very near to all who call on Him. 
LISTEN to His wonderful words as assurance, spoken through the prophet Isaiah: "Fear not, for I am with you; be not dismayed, for I am your God. I will strengthen you, yes, I will help you, I will uphold you with My righteous right hand." Isaiah 41:10.

\section{BREAKING THE CYCLE OF LONELINESS}

FIRST - Listen, and then answer back. Start talking to the One who know's you intimately. If you're shy and introverted, that can become a strength. It can become a resource, not just a liability.

* SECOND - Open up the Word of God, look at the stories of Jesus, and start talking back. Opening up to God is the first step you can take toward opening up to life in general and other people in particular.

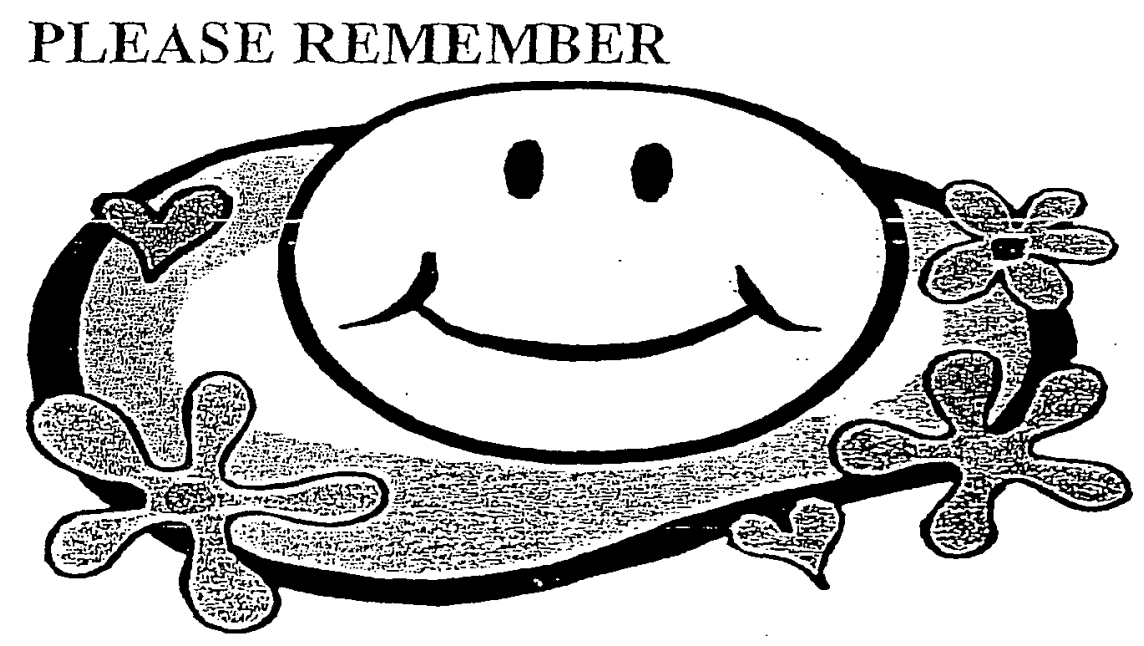

The energy we need to start us moving out of our little circle of loneliness comes down to this: RESPONDING TO THE GOD WHO CALLS US BY NAME.

We've got believe that He really is there.

We've got to start listening for that voice. 


\section{GOD'S PERSONALIZED PLAN}

Used by permission: Dan Houghton [dhoughton@hartresearch.org] email June 14, 2005

$$
\text { Read - Psalm 139: 5-18 }
$$

* You have hedged me behind and before (v5).

* Such knowledge is too wonderful for me (v6).

* Where can I go from Your Spirit? (v7)

* If I ascend into heaven, You are there; if I make my bed in hell, behold You are there (v8).

* How precious also are Your thoughts to me, O God! How great is the sum of them (v17).

* If I should count them, they would be more in number than the sand; When I awake, I am still with You (v18).

We may resist that love. We may reject that love. But we cannot avoid that love. We cannot run away from God's love. Around every corner, we come face to face with Him. He is there calling, wooing, entreating, appealing tenderly. (LNL, 13) 


\section{Eod"s \\ personalized \\ plan}

\section{Where are you?}

God's Pursuing Love is Overwhelming.

Psalms 139: 5-18

Verse 5

Verse 6

Verse 7

Verse 8

Verse 17

Verse 18

\section{We can't get away!}

God longs to save you. He has a pre-designed plan to win you back. Daily, He calls you. You can be secure in a love like that. For God has taken the initiative. He is on your side. And that makes all the difference in the world! 


\section{SCRIPTURE ASSURANCE}

Used by permission: Dan Houghton [dhoughton@hartresearch.org] email June 14, 2005

JESUS

John 1:9

If we confess our sins, He is faith and just to forgive us our sins and cleanse us from all unrighteousness.

HOLY SPIRIT

Romans 2:4 Or despisest thou the riches of his goodness and forbearance and longsuffering; not knowing that the goodness of God leadeth thee to repentance?

\section{ANGELS}

Hebrews 1:14 Are they not all ministering spirits sent forth to minister for those who will inherit salvation?

DIVINE PROVIDENCE

Romans 8:29, 30

For whom He foreknew, He also predestined to be conformed to the image of His Son, that He might be the firstborn among many brethren. Moreover whom He predestined, these He also called; whom $\mathrm{He}$ called; these $\mathrm{He}$ also justified; and whom $\mathrm{He}$ justified, these He also glorified.

Jeremiah 1:5 Before I formed you in the womb I knew you; Before you were born I sanctified you; And I ordained you a prophet to the nations. 


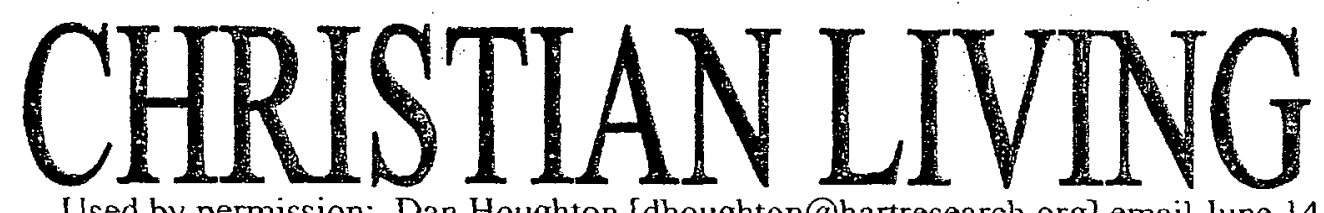

Used by permission: Dan Houghton [dhoughton@hartresearch.org] email June 14, 2005

\section{CERTAINTIES}

o Knowing our SINS are FORGIVEN.

o Sensing that GOD accepts us.

o Valuing OURSELVES as God values us.

○ Coping with TEMPTATIONS.

o Knowing God's WILL. 


\section{CERTAINTIES of CHRISTIAN LIVING}

\section{Security and Assurance}

Our sense of security and assurance - Luke 1:4

- Knowing our __ are

- Sensing that ___ accepis us.

- Valuing ___ as God values us.

- Coping with

- Knowing God's

\section{Scripture Assurance}

Jesus.............................. John $1: 9$

Holy Spirit....................... Romans 2:4

Angels........................... Hebrews 1:14

Divine Providence................ Romans 8:29, 30; Jeremiah $1: 5$ 


\section{SESSION 5}

\section{PEACE OF MIND PART II:}

\section{FIVE TOPICS FOR GRIEVERS}

Snowflakes

You Are Valuable

New Heart .

Doubt.

Forgiveness..

Exercise: Hebrews 11:1-22; Genesis 11:27-25:11 


\section{SNOWFLAKE}

Used by permission: Dan Houghton [dhoughton@hartresearch.org] email June 14, 2005

Snowflakes are temporary works of art.

After just a few short minutes on the ground, a fallen snowflake will lose its ornate structure, its unique pattern that will never again be repeated

Most children that grow up in "cold country" will find themselves outside on a snowy day trying to catch a snowflake on their tongue. This was an interesting and exciting feat for my siblings and I having grown up in Missouri. We even enjoyed ice cycles although we were warned time and time again that they would give us a sore throat. There was just something about these little fun things that we were willing to sacrifice our ALL just to enjoy for season.

\section{YOU ARE ONE OF A KIND}

There is one thing God does not have unless you give it to Him and that is your

\section{LOVE \\ (Your Allegiance)}




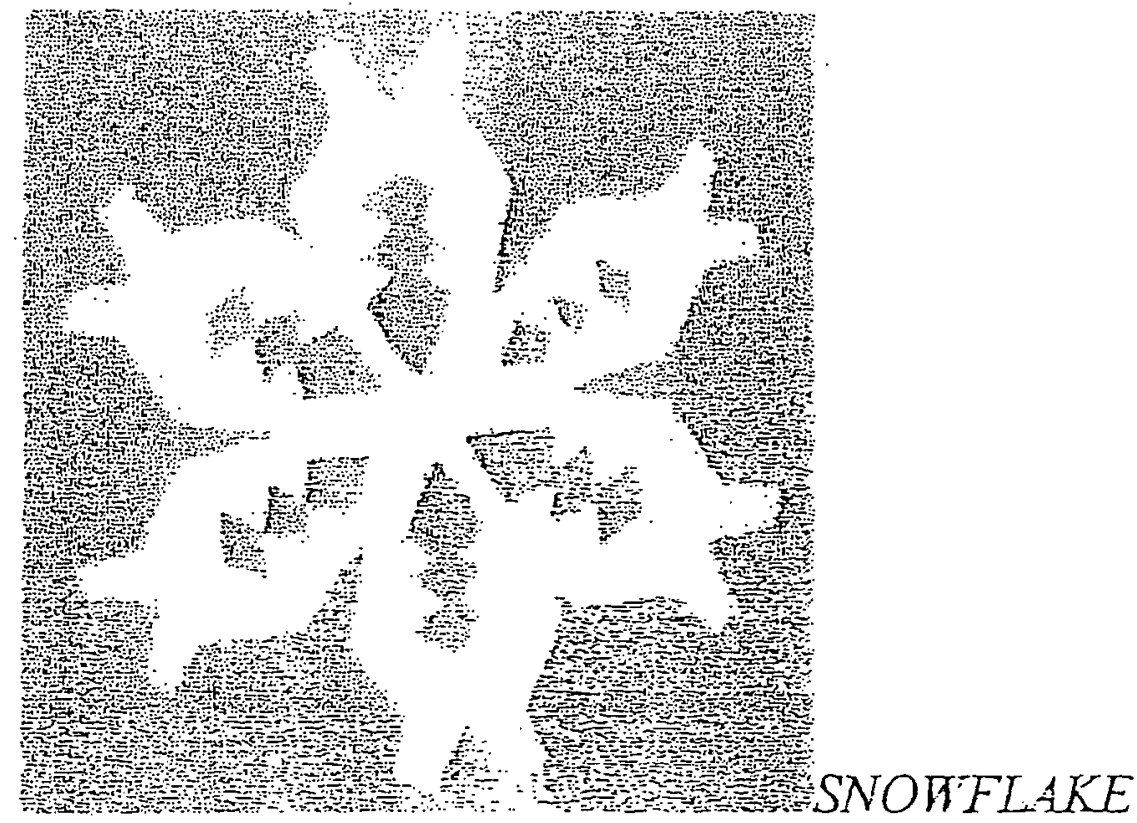

\section{YOU ARE ONE OF A KIND}

When Swiss Lace Makers make their beautiful lace, they sometimes design their patterns from a single snowflake. Each snowflake has a different pattem. You are like that Snowflake - individually created by God, one of a kind, special, unique.

There is something God does not have unless you give it to Him and that is your

When you and I come to Christ, realizing that we have immense worth in His sight, that He created us individually, we become His. We are His sons and daughters. We're part of the royal ramily of heaven - related to the King of the Universe.

Please answer the following questions by circling the answer of your choice:

YES NO Has this glorious fact dawned upon your consciousness yet?

YES NO Has the marvelous truth that you are Christ's filled your mind?

Used by permission: Dan Houghton[dhoughton@hartresearch.org] email June 14, 2005. 


\section{You are His by Creation}

* He made you;

* He fashioned you;

* He has given you life.

\section{You are His by Redemption}

* You are purchased by His blood.

$\because$ You are not merely one of billions of people clawing at one another for living space in the universe.

$\because$ You have royal blood running through your veins.

The individual sheep was possessed by the Shepherd, and you become the possession of Jesus Christ. You are His. He cares for you. He loves you as if you were the only one in the world.

Calvary shouts to us,

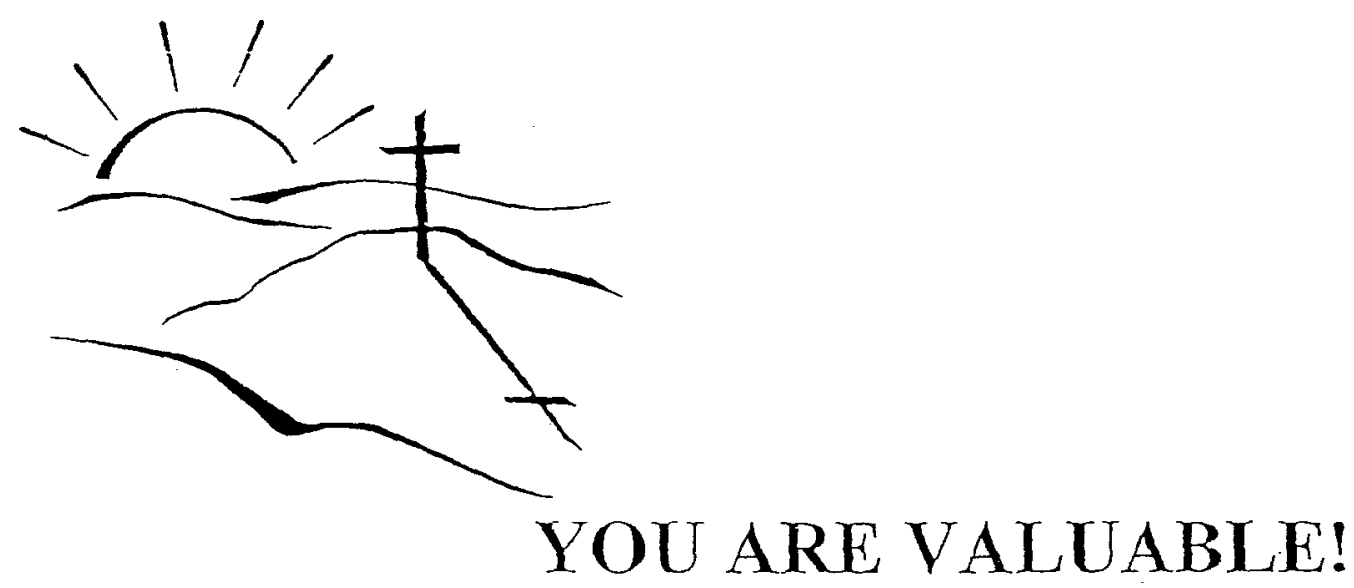

Used by permission: Dan Houghton[dhoughton@hartresearch.org] email June 14, 2005. 


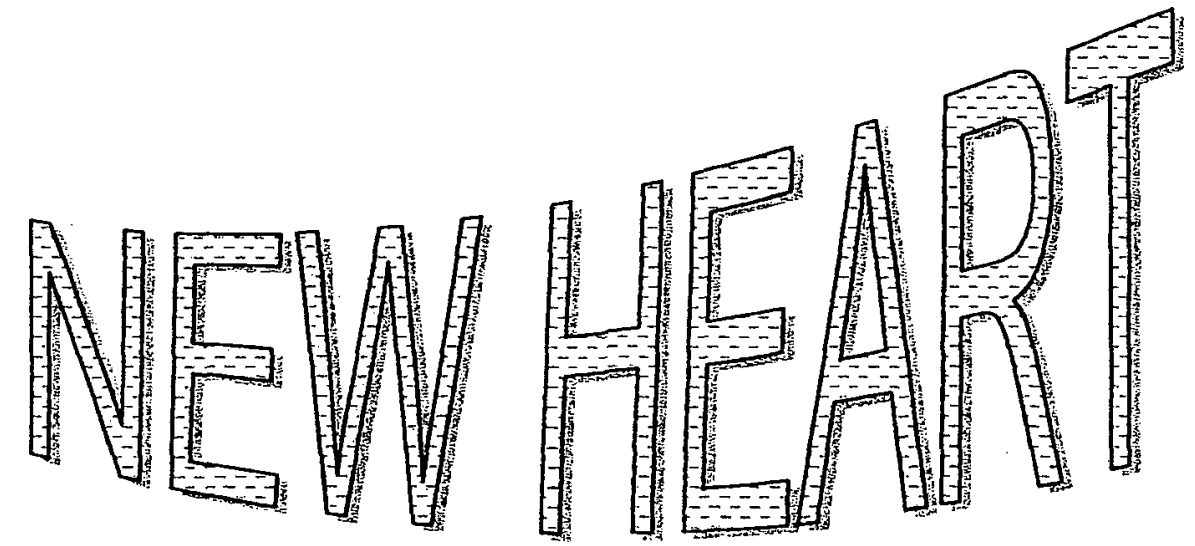

Used by permission: Dan Houghton [dhoughton@hartresearch.org] email June 14, 2005

IDENTITY

SECURITY

POSSIBILITIES

DESTINY 


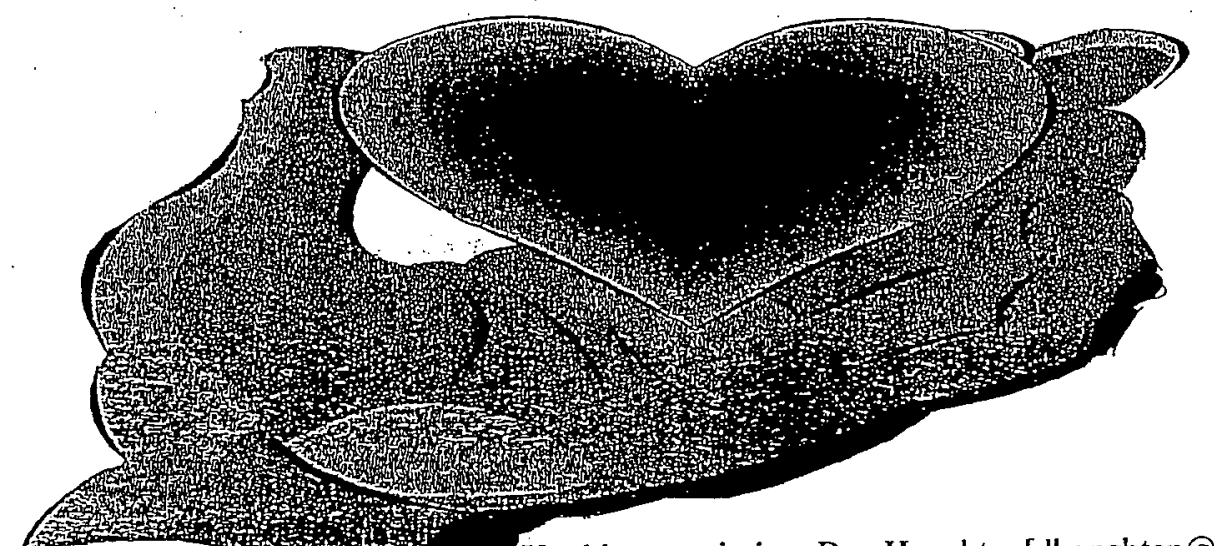

Used by permission: Dan Houghton[dhoughton@hartresearch.org] email June 14, 2005.

\section{YOU ARE IN GOOD HANDS CHRIST JESUS}

- We have a new a new selí

concept. Adoption as God's Children. Ephesians $2: 19,5: 1 ; \quad 1$ John $3: 1,2$.

Our identity is found ONLY in our relationship with God. God is our Father, Jesus Christ is our brother. Our past no longer defines our life's true history. We may abandon all our efforts to impress others with our looks, money, clothes, position or achievements. We may abandon all our feelings of inadequacy and inferiority because of our past. Our Father is the King of the universe!

- We have a new knowing that Christ has provided both freedom from guilt and power for victory. Angels descend from the throne of Grace, and the Holy Spirit ministers to our hearts (Ephesians 1:6, 7).

It is this forgiveness and acceptance which motivates our good behavior. Secure in His grace as His sons and 
daughters, we desire to please Him. With new hearts (Ezekiel 36:26) having the principles of His law on it (Hebrews 8:10), the Holy Spirit gives us power to obey (John 3:5,6); and we have a desire to do His will (Matthew 26:39; John 8:29)

- We have new we have access to all the divine power of Christ as He reside in us through the Holy Spirit. (Ephesians $1: 13,14)$

As we remain in Christ, all things are possible through Him. We are not left to struggle alone with the hereditary and genetic impossible, ingrained urges to sin. (1Corinthians 10:13)

- We have a new which is ours!

This world is not our permanent home. Our eyes are fixed on a world yet to come. Our home is to make HEAVEN our home. (Ephesians $1: 10,21,22)$

Look Up! In Christ we have a self-identity - for love, for acceptance, for self-realization and for our ultimate destiny - All this is already ours! 


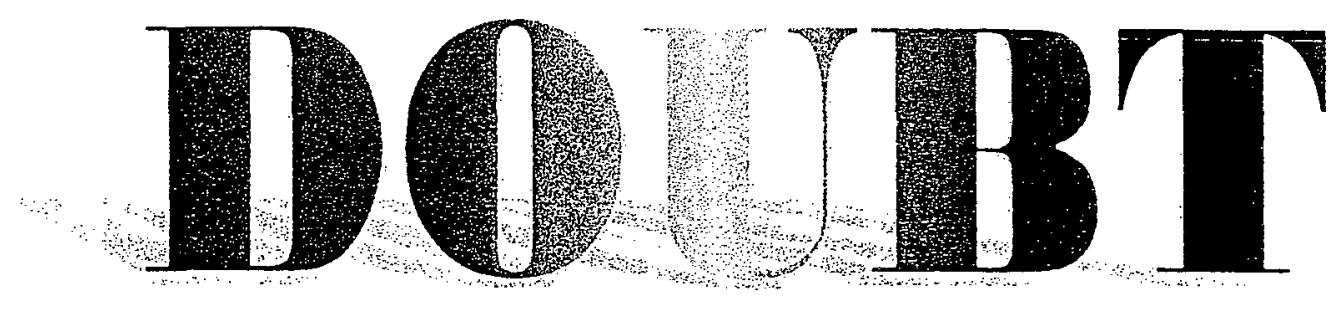

Used by permission: Dan Houghton [dhoughton@hartresearch.org] email June 14, 2005

$$
\text { DOUBTING GOD'S LOVE }
$$

\title{
DOUBTING THEY'RE CHILDREN OF GOD
}

\author{
DOUBTING THAT SALVATION IS \\ POSSIBLE
}

\section{WHEN CHRISTIANS DOUBT THEY LACK ASSURANCE AND BECOME VULNERABLE




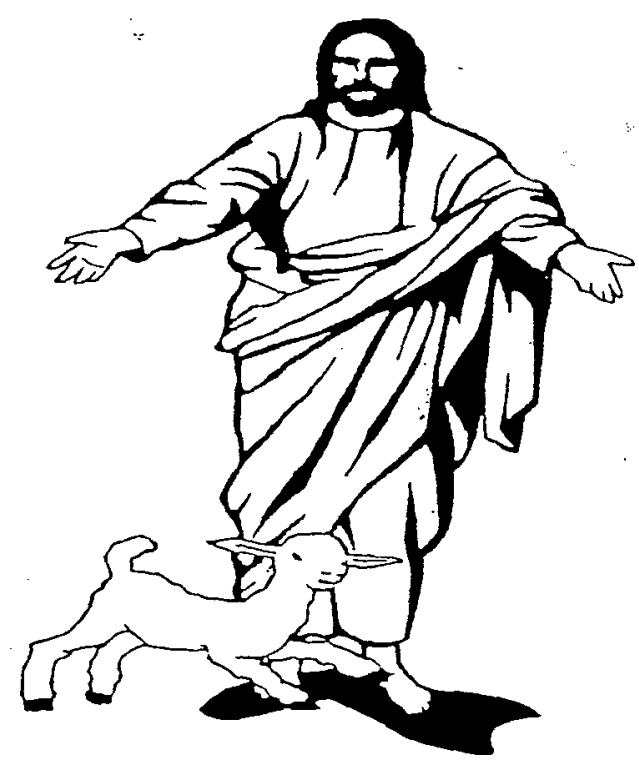

\section{WITHOUT DOUBT}

Used by permission: Dan Houghton[dhoughton@hartresearch.org] email June 14, 2005.

At times, we are doubting Christians.

- We doubt our sins are forgiven. Guilt plagues us.

- We doubt we are accepted by God. We feel insecure.

- We doubt eternal life is ours. We feel afraid about the future.

Doubt is destructive. It is one of Satan's greatest weapons.

Our Heavenly Father deals in assurance. He wants you and $I$ to have the assurance that our hand is in His hand.

- Trat our sins are forgiven.

- That we are children of God.

- That all the power necessary to live the Christian life is ours.

Let us read 1 John 5: 12, 13(KJV):

He that hath the hath life; and he that the Son life. (Verse 12) 
These things have I written unto you who in the

name of the Son of God; that you may know that ye have , and that you may on

the name of the Son of God. (Verse 13)

Coming to Jesus does not require severe mental effort or agony. It is making an intelligent choice to accept by faith the sacrifice of Christ on Calvary as your own. He died that we might live. When we make the rundamental decision, all the privileges of being a child of God are ours.

- Look away from your fears.

- Look añay fiom your doubts.

- Look away from your weakness.

- Look away from your sins.

- Believe that God loves you. In Christ He has pardoned you you are His child.

Isaiah 45:22 says, "Took to me, and be saved, all you ends of the earth! For I am God, and there is no other."

Salvation is a matter of:

- Looking

- Choosing

- Deciding

- Depending upon Jesus

- Faith in Jesus

Hebrew 12:1, 2 say, "Looking unto Jesus, the author and finisher of our faith." 


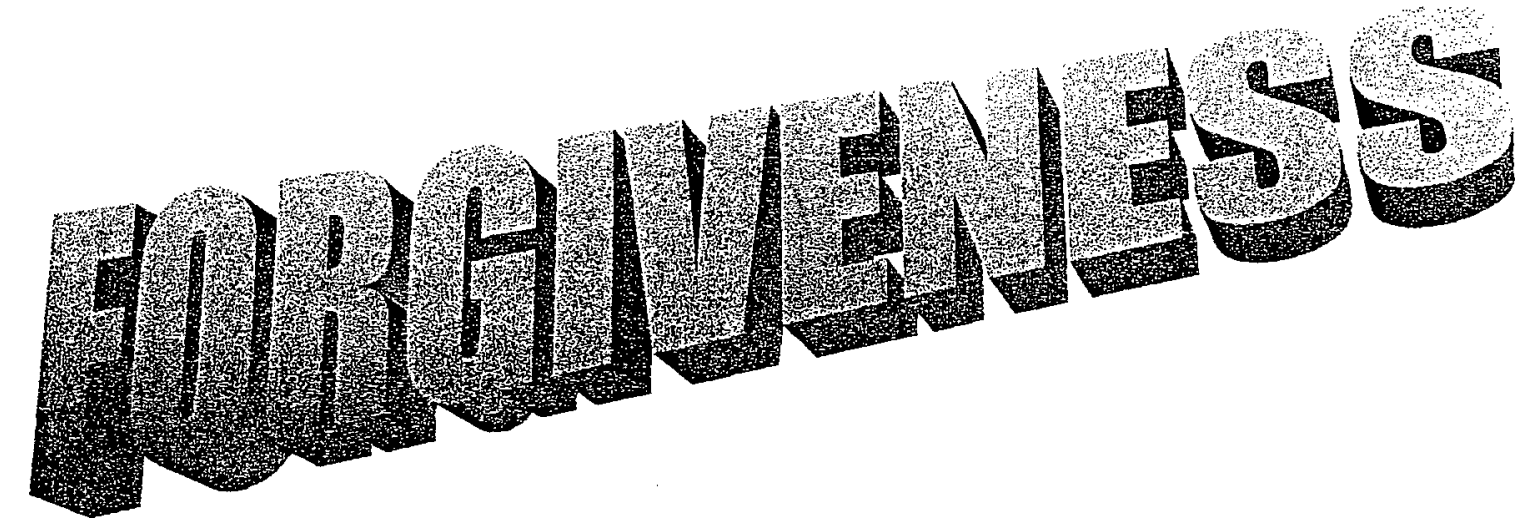

Used by permission: Dan Houghton [dhoughton@hartresearch.org] email June 14, 2005

Forgiveness is an Attitude Adjustment

Sometimes when a loved-one dies there is a lot of pain relative to their behavior toward us.

$>$ They may have been abusive (verbally, emotionally, and/or physically).

$>$ They may have been aloof and distant for a long period of time.

$>$ You may have felt responsible for their death in some way-blaming yourself.

$>$ Your thoughts may not be what you think they should be relative to their death.

$>$ Their may have been feelings of anger and resentment.

Forgiveness allows for the griever to be liberated from all of these negative thoughts and feelings.

Forgive the deceased and forgive yourself. 


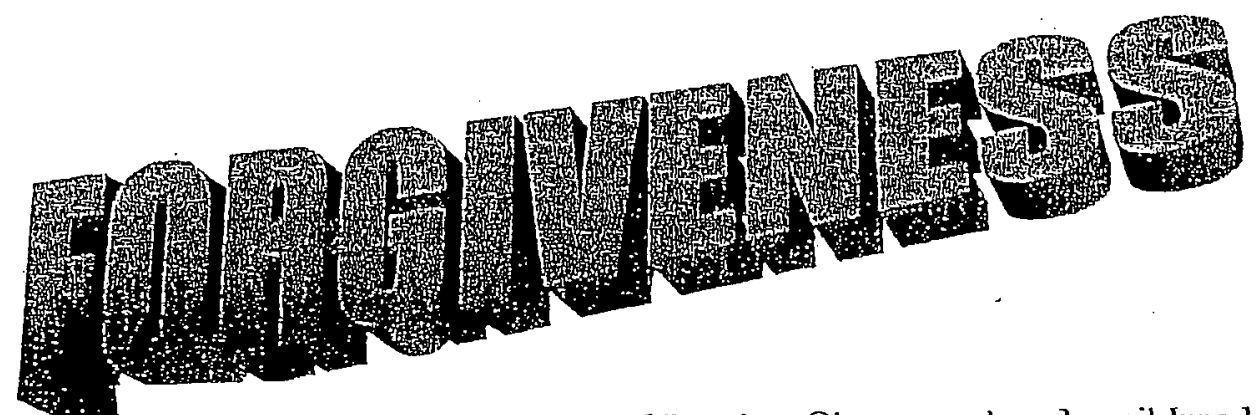

Used by permission: Dan Houghton[dhoughton@hartresearch.org] email June 14, 2005.

\section{Is an Attitude of Mercy toward those who have wronged us (you and/or I).}

Forgiveness is rooted in God's nature.

- He is gracious and merciful.

- He holds no grudges.

- He harbors no resentments.

First - Forgiveness is rooted in the very heart of God. (Luke 15) It is rooted in the very essence of the character of God.

CONFESSION - is not to plead with God to give us something that He doesn't long to give us already.

- Forgiveness is not something we earn by confessing our sins.

- Forgiveness is something we receive by confessing our sins.

- Our confession does not alter God's mind.

- Our confession does not change God's attitude toward us.

- Confession enables us to appreciate God's attitude toward us.

Matthew 18:21-22 "Then came Peter to him (Jesus), and said, Lord, how oft shall my brother sin against me, and I forgive him? Till seven times? Jesus saith unto him, I say not unto thee, until seven times: but until

\section{Forgiveness is}


Second - God provides forgiveness through Jesus independent of anything we do. Forgiveness never rises from our prayers but from Christ's prayer. While wicked men were crucifying Him, Jesus prayed, "Father, forgive them, for they know not what they do."

"That prayer of Christ for His enemies embraced the world. It took in every sinner that ever lived or should live from the beginning of the world to the end of rime." Desire of Ages, p. 745.

Just as Christ forgave His enemies before they asked, so forgiveness flow's from the heart of God before we ask.

When we become Christians, we are adopted into the family of God. We become Children of God. The Father loves us as He loves His own Son. Romans 8:14, 15.

"For as many as are led by the Spirit of God, they are the of God, for ye have not received the spirit of fear of bondage again to fear; but ye have received the whereby we cry, Abba, Father."

Third - We must individually accept God's forgiveness before it effects our salvation. Confession is vitally important for at least two reasons:

1. God respects freedom of choice. His forgiveness never works changes in me unless I desire it. It can never pardon my sins unless I personally embrace it.

2. Every act of disobedience, disloyalty, and rebellion reacts upon us. If we fail to recognize that sin builds barriers berween us and Christ, we will become spiritually hardened.

Confession softens our hearts, keeps our moral system clean, enables God to help us when we need it most and enables Him to minister healing to our hearts. 


\title{
SESSION 6
}

\section{BIBLICAL ROLE MODEL}

\author{
ABRAHAM
}

Abraham

End of the Seminar

Exercise: Evaluation 


\section{A Biblical Role Model - Abraham}

In Genesis Chapters $12-25$ we enter into the experience of Abraham and understand how he dealt with his sufferings. Abraham's life begins for us at the age of seventy-five when he receives a call from God to leave his father's house and go to a place that he would be shown. This is an interesting, yet challenging request. We envision him leaving his homeland, Ur of the Chaldees, but he is not alone in his departure; his father Terah; wife Sarai; and nephew Lot, are a part of the caravan as they journey to the land of Canaan in search of the "promised land." He leaves behind the grave of his brother Haran (Lot's father) who died suddenly; and his brother Nahor who chooses to remain in Ur. At the border of Canaan (in Haran) Terah dies (11:31-32). In spite of these two deaths the family entered Canaan.

As we explore Abraham's one hundred years in Canaan and his relationship with God, we will walk with him through the shadows of his sufferings. As an alien in a foreign land we will see him interacting and interrelating with family members, slaves and countrymen. Let us consider this question in the back of our minds as we begin our journey through Genesis 12:1 - 25:11. “How does Abraham's suffering serve as a model for us today in dealing with deaths, separations, losses, and griefs?"

Let us investigate this faith, for God never changes. With the help of contemporary authors we will observe the faith landmarks provided for us in the life and journey of Abraham. This will enable us to take hold of the spiritual lessons and apply them to our lives today in order to understand how faith produces obedience in relationships with God. Therefore, Abraham's sufferings will serve as a biblical model 
for us in the twenty-first century as we deal with our struggles with deaths, separations, losses and griefs.

The first twenty-five years (Gen 12:4; $21: 5$ ) in Canaan were Abraham's most eventful years. We will immediately observe him as he seeks to know God, gain an understanding of the nations around him, and deal with his personal challenges in the areas of spiritual growth and development.

\section{From the Oaks of Moreh to the Hill Country}

As the caravan begins to set up camp among the Oaks of Moreh, the first rest stop in Canaan, Abram silently waits for a sign from God.' Gazing upon the two mountains at a distance, Mount Ebal and Mount Gerizim, whose majestic peaks point to the heavens and testify of God's creative power, Abram wonders about the awesomeness of this God whom he has chosen to obey. The journey was long and tiring, he might well find himself reflecting upon the call God made to him and its promises (12:1). Abram's question may have been, "Lord, is this the place?"

As the sun sets in the west and darkness envelops the caravan, something wonderful happens, for the first time the Lord appears to Abram and says, "To your offspring I will give this land" (12:7). These words brought joy to the heart of Abram and called for a celebration of praise and thanksgiving; they had reached the land that God had promised to show him (12:1). So Abram built an altar to the Lord, who had appeared to him, and they worshiped Him.

For Abram this meant three things: 1) letting go of the past; 2) embracing the present; and, 3) planning for the future.

\footnotetext{
'Paul F. Bork, Out of the city. Across the Sands. (Washington, DC: Review and Herald Publishing Association, 1982), $81-82$.
} 
By faith Abraham obeyed when he was called to go out to the place which he would afterward receive as an inheritance. And he went out, not knowing where he was going. By faith he sojourned in the land of promise as in a foreign country, dwelling in tents with Isaac and Jacob, the heirs with him of the same promise; for he waited for the city which has foundations, whose builder and maker is God (Heb 11:8-10).

His relationship with God had changed. God was no longer just a voice; he had made visual contact and he could believe in Him and trust His word.

This three-fold sequence similar to Glasser's (see page 6) is echoed in Paul's

letter to the brothers and sisters in Philippi relative to breaking with the past.

Not that I have already obtained this or have already reached the goal; but I press on to make it my own, because Christ Jesus has made me his own. Beloved, I do not consider that I have made it my own; but this one thing I do: forgetting what lies behind and straining forward to what lies ahead, I press to the goal for the prize of the heavenly call of God in Christ Jesus (Phil 3:12-14).

\section{Famine, Sojourn to Egypt, and Sarah in Pharaoh's Harem}

Disaster struck in the land of Canaan, there was a famine in the land. This changed their goal to the survival of the family. Abram went down to Egypt with Sarai and Lot to reside there until the famine subsided.

Before entering Egypt, Abram became aware of the customs, attitudes, and behavior of the idolatrous Egyptians relative to fair and beautiful women for Pharaoh's harem.'

Out of fear for his life, Abram and Sarai agreed to use the "sister" aspect of their relationship in an effort to spare his life if they were confronted with this situation. Soon after reaching Egypt it became a reality. Sarai was taken into Pharaoh's house $(12: 10$ -

1 "The Pharaohs are known to have fancied the fairer complexion of foreign women, and to have secured Libyan, Hittite, Mesopotamian, and Palestinian girls for the royal harem." Genesis to Deuteronomy, SDA Bible Commentan, ed. F.D. Nichol (Washington, DC: Review and Herald Pub. Assn., 1978), $1: 298$. 
15). Then Pharaoh lavished Abram with sheep, oxen, male/female donkeys, camels, and male/female slaves (12:16), in exchange for his sister (wife).

What was to follow was unexpected for Abram and Pharaoh; the Egyptians act of taking possession of another man's wife became a curse. For the Lord afflicted Pharaoh and his house with great plagues because of Sarai (12:3), resulting in Pharaoh's personal dialogue with Abram, returning Sarai to him; and, ordering his men to escort them and their possessions to the border (12:17-20).

\section{Separation from Lot, War, and Rescue}

This trip back to Canaan became full of antipathy because of the wealth Abram and Lot had obtained in Egypt. Their flocks and herds so numerous, there was strife over pasture among their herders. Abram was faced with the inevitable decision, the need for separation between him and his nephew (13:8-13). Abram, Sarai and Lot entered Canaan together as a family unit and now prosperity had driven a wedge between them.'

God's command here seems to offer comfort to Abram:

Raise your eyes now and look... [As Abram, in obedience, looks up and around him, in compassion and love the Lord pulls back the veil of time and reveals the future to Abram as if it had taken place in the moment.] For all the land that you see I will give to you and your offspring forever. I will make your offspring like the dust of the earth ... Rise up, walk through the length and the breadth of the land, for I will give it to you (13:14-17).

When Abram returned from his walk with God, he was refreshed and commanded the tribe to break camp. Abram moved his tent and settled again by the Oaks of Mamre

\footnotetext{
1 "Abram had given Lot the choice, with extraordinary generosity, all the more generous in a patriarchal situation where Abram was very definitely the head of the Clan. It is anyway a sad decision for Abram: He still has no heir and now loses a possible substitute and family help . . also the most fertile land." Henry Wansbrough, Genesis: Doubleday Bible Commentary (New York: Doubleday, 1998), 27.
} 
and there he built an altar to the Lord (13:18). Once again there was peace, tranquility, and harmony in the camp.

One day Abram had a surprise visit. Mamre, the Amorite and his brothers, Eshcol and Aner (they were allies of Abram), came to the camp with very bad news. Mamre had escaped a raid by King Chedorlaomer. In Mamre's concluding statement he revealed that Lot had been taken captive. Obviously Abram still had a strong love for Lot and his family. Abram gathered his three hundred and eighteen trained servants together with his allies and pursued King Chedorlaomer and his army. When Abram's contingent arrived at Dan they assessed the situation and waited until night to attack.' It appears that this successful mission fulfilled the will of God.

\section{Abraham Faces His Mortality and the Covenant Relationship}

It is evident from the conversation in Chapter 15 that Abram is troubled by his childlessness. Abram is able to speak freely about his fear of dying without an heir. Notice his response in verse 2, "O Lord God, what will you give me, for 1 continue childless and the heir of my house is Eliezer of Damascus." God firmly responds to Abram's plea with "no" and proceeds to enlarge on his original call, "to make you (Abram) a great nation" (12:2). This is the first time the Lord specified clearly, "no child but your very own issue shall be your heir" (15:4). To solidify this profound statement, Abram is escorted outside and told to, "Look toward the heavens and count the stars. If you are able to count them, so shall your descendants be. Abram believed God and it was reckoned to him as righteousness" $(15: 5,6)$.

\footnotetext{
1 "So in the darkness and the confusion caused by his (Abram's) sudden attack from different quarters, Abram routed the Elamites, recovered the spoil and his captive nephew. With large booty and the rescued Abram returned in peace to the Valley of the Jordan." William J. Deane, Men of the Bible: Abraham His Life and Times. (Chicago, IL: Fleming H. Revell Company, 1942) 1: 68, 69.
} 
God recapitulated the beginnings of their relationship and Abram responded, " $O$ Lord God, how am I to know that I shall possess it (this land)?" $(15: 7,8)$. God seals a covenant with a sacrifice and a vision. The Lord moves within the vision in a way that Abram is rendered powerless and helpless $(15: 12,17)$ ' $^{\prime} \quad$ This vision is vivid and very pronounced. $^{2}$

There are five prophetic events that will take place relative to this covenant (Gen 15:15-21): 1) Abram will live to a good old age and die; 2) His offspring will be aliens and oppressed slaves for four hundred years; 3) God will bring judgment on that oppressing nation; 4) His offspring shall come back to the land in the fourth generation and possess it from the river of Egypt to the river Euphrates; and, 5) The iniquity of the Amorites will be complete.

It is good for us to come to grips with the reality that God knows each of His children very well and makes Himself known to them in different ways, depending on the maturity of the relationship with Him. As we grow in grace He allows us to see different aspects of His character. He may not speak or come to us in tangible ways but we have the assurance of God's presence. Abram at times strayed from God's plan. Even in our weakness God accomplishes His purpose.

\footnotetext{
'Keith Essex expresses it this way, "This particular 'covenant' is not a mutually binding obligation. A deep sleep (cf 2:21) falls upon Abraham and only the Lord, represented by a smoking oven and a flaming torch, passes between the animals." Keith H. Essex, "The Abrahamic Covenant," The Master's Seninarn: Joumal 10, no. 2. (Fall 1999), 201.

2 "Yahweh 'cuts' a covenant with Abraham. The use of this Hebrew word karat ("cut") points us to the inauguration of a new phase of covenant relationships, [it] serves as a guarantee of such confirmation . . it gives solidity to it and quazi-legal backing for it . . "W. J. Dumbrell, "The Covenant with Abraham," The Reformed Theological Review Vol. 41, (May-August 1982), 42.
} 


\section{Hagar's Marriage and Flight and the Birth of Ishmael}

In Genesis 16 Sarai brings her personal woe to Abraham. Surrogate parenthood was her suggested solution to her grief in her barren condition, so she offers her Egyptian slave Hagar, as a wife to Abram (vss.3,4). $\quad$ Hagar conceives and looks with contempt on her mistress. Sarai returns to Abram, blaming him and complaining about Hagar, "May the wrong done to me be on you." His response, "Your slave is in your power, do to her as you please," empowers her to reprimand Hagar (vss.5, 6). Hagar runs away.

This was distressing news for Abram because Hagar could only go to the desert with his child. The drama was short lived when Hagar returned to camp saying she met God. He named her child Ishmael, and revealed his personality and character traits. Hagar submitted to Sarai and bore a son (vss.7-15). Abram now had an heir and their gnief was temporarily resolved.

\section{Abraham's Bargains with God over Sodom}

In Genesis 18, Abraham had three visitors. Abraham hosted them graciously and one of them revealed himself to be God, promising them the birth of a son. Sarah laughs at the idea but, God said, "Is anything too wonderful for the Lord?" (v.14). Two of the guest proceed on their way but God draws Abraham aside to reveal his purpose for

Sodom. The Lord says,

Shall I hide from Abraham what I am about to do, seeing that Abraham shall become a great and mighty nation, and all the nations of the earth shall be

1 "Her barren condition was a heavy burden for her, and although being of Abraham's household, she was unable to cooperate in building of that household. Her opprobrium was bitter, like death and nothingness. It was not only a privation of the joy of possession, but a denial of the normal purpose of her existence." Angel Gonzalez, Abraham Father of Believers (New York: Herder and Herder, 1967) 66.

${ }^{2}$ Sarah [she] laughs at the sheer impossibility of the thing ... she is ecstatic at even the thought that, after all these years, she and her husband will experience those transcendent pleasures again. Patrick T. Reardon, "Sarah Laughed," U.S. Catholic Vol. 65, no.1, (January 2000), 43-45. 
blessed? No, for I have chosen him that he may charge his children and his household after him to keep the way of the Lord by doing righteousness and justice; so that the Lord may bring about for Abraham what he has promised.

Then the Lord says to Abraham,

How great is the outcry against Sodom and Gomorrah and how very grave their sin! I must go down and see whether they have done altogether according to the outcry that has come to me; and if not, I will know (18:17-21).

Abraham appeal to the Lord for mercy, obviously full of concern for Lot and his

family.

Will you indeed sweep away the righteous with the wicked? Suppose there are fifty righteous within the city will you sweep away the place and not forgive it for the fifty righteous who are in it? Far be it from you to do such a thing, to slay the righteous with the wicked. Far be it from you! Shall not the Judge of all the earth do what is just? (18:23-25).

The Lord in His compassion responds, "If I find fifty righteous in the city, I will forgive the whole place for their sake" (18:26). Abraham bargains from fifty, to forty-five, to forty, to thirty, to twenty, and finally to ten. God's response, "For the sake of ten I will not destroy it" (18:28-33). The thought of eradication of Lot's family along with the Sodomites is a source of great concern for Abraham and believing in God's justice he allows God to go on His way.

"Abraham went early in the morning to the place where he had stood before the Lord; and he looked down toward Sodom and Gomorrah and toward all the Land of the Plain and saw the smoke of the land going up like the smoke of a furnace" $(19: 28,29)$. Abraham must have believed that God spared Lot and his family as he looked at the catastrophe. So it was that, when God destroyed the cities of the Plain, God remembered Abraham, and set Lot out the midst of the overthrow" (19:29). 
Much later when Jesus sojourned on Earth, in His Luke 17 conversation relative to the coming of His Kingdom, He refers to this time and says, "Likewise as it was also in the days of Lot ... on the day when Lot went out of Sodom it rained fire and brimstone from heaven and destroyed them all." The Apostle John in the Book of Revelations picks up the prophecy (Rev $19: 20 ; 20: 10,15 ; 21: 8)$ as the finale of the great controversy. All who are not written in the Book of Life will have their part in this lake of fire and brimstone, which is the second death. ${ }^{1}$

\section{Abimelech's Court, the Birth of Isaac, Hagar and Ishmael Sent Away}

From there Abraham settled between Kadesh and Shur, Genesis Chapters 20 and 21. Abraham has a second faith failure over Sarah's safety but God intervenes with the heathen king, Abimelech. God gives King Abimelech a dream that announced Abraham as a "prophet" with the power to pray for him, "Now then, return the man's wife; for he is a prophet, and he will pray for you and you shall live" (20:7). When Abimelech tells Abraham the dream, Abraham confesses his sin. Sarah is retumed to Abraham with gifts. Abraham prays for healing of Abimelech's household. In response God opened the wombs of the women in Abimelech's household and they bear children.

Some time after this Sarah conceived and bears Isaac. Sarah acknowledging God's blessing with the words, "God has brought laughter for me; everyone who hears will laugh with me. Who would have said to Abraham that Sarah would nurse children? Yet I have borne him a son in his old age" $(21: 6,7)$.

\footnotetext{
1 "The Lake of fire is the last description of the Bible of final punishment. The fiery lake of burning sulphur does not appear anywhere else in the Bible. Even so, conditionalists and traditionalists agree that it stands for the same ultimate destiny which in the Gospels (but nowhere else in Scripture) is pictured under the name of "Gehenna." Edward William Fudge, The Fire that Consumes the Biblical Case for Conditional Immortality, (Carlisle, UK: The Patemoster Press, 1994), 191.
} 
Now there were two heirs, Ishmael and Isaac. This created a problem for Sarah.

So upon seeing Ishmael scoffing at Isaac she immediately goes to Abraham and says,

"Cast out this slave woman with her son; for the son of this slave woman shall not inherit along with my son Isaac" $(21: 10)$.'

. The Bible says, "The matter was very distressing to Abraham on account of his son [Ishmael]" (21:11). God's grief ministry was, "Do not be distressed because of the boy and because of your slave woman; whatever Sarah says to you, do as she tells you, for it is through Isaac that offspring shall be named for you. As for the slave woman, I will make a nation of him also, because he is your offspring" $(21: 12,13)$. The obedience of Abraham is the key to his relationship with God. Abraham provided bread and a skin of water, and then sent them off $(21: 14)$.

\section{Isaac on Mount Moriah and Sarah's Death}

It would seem that small trials and tribulations in life are preparation for the big challenge. God tested Abraham by commanding him to offer his son Isaac as a sacrifice on a mount in the Land of Moriah in Chapter 22. Abraham did not hesitate; he rose early that morning, collected the sacrificial accessories, saddled his donkey, took Isaac and two young lads, and joumeyed for three days in search of "the place."

There appears to be silence between father and son as Abraham anticipates the crisis. When Abraham sees his destination in the distance, says to his servants, "Stay here

\footnotetext{
'Sarah seeing the two brothers together realized ... if they were too alike then Ishmael would pose a threat to Isaac's inheritance. She knew Abraham's positive feeling toward his firstborn son. Isaac's clear identity was at stake, and in Sarah's eyes Isaac could not grow up to be himself if Ishmael, his other side, was constantly present. Noman J. Cohen, Self. Struggle \& Change: Family Conflicts Suries in Genesis and Their Healing Insights for Our Lives, (Vermont: Jewish Lights Publishing, 1995), 71-73.
} 
with the donkey; the boy and I will go over there; we will worship, and then we will come back to you"l (22:5). Apparently Abraham is taking a leap of faith.

As they walk along together, Isaac senses in his father the intense pain. In his innocence he inquires, "Father!" The fire and the wood are here, but where is the lamb for the burnt offering?" (22:7). Abraham once again responds in faith, "God Himself will provide the lamb for a burnt offering" (22:8). At the chosen site Abraham builds the altar, places the wood on top and Isaac on top of the wood. He raises the knife, "but the angel of the Lord called to him from heaven, and says, 'Do not lay your hand on the boy or do anything to him, for now I know that you fear God, since you have not withheld your son, your only son from me"' (22:12). ${ }^{2}$ At this point the prophecy of Genesis 22:8 fulfilled immediately, for Abraham sees a ram in the thicket caught by his horns. This ram became the substitute sacrifice. God delivered him from his emotional anguish.

By myself I have sworn, says the Lord: Because you have done this . . I will indeed bless you, and I will make your offspring as numerous as the stars of heaven and as the sand that is on the seashore. And your offspring shall possess the gate of their enemies, and by your offspring shall all the nations of the earth gain blessing for themselves, because you have obeyed my voice (22:15-18).

The next big event in the life of Abraham is the death of Sarah. He mourns and weeps for her. He purchased the burial cave from his Hittite neighbors. The sympathetic Hittites complied with his wishes.

\footnotetext{
1 "Nothing could seem more incongruous than that God would ask Abraham to sacrifice his son. Apan from the revulsion at such an idea and the natural affection of Abraham for the son whose coming was so long awaited, the son is the very heart of the covenant promise. If he dies, the covenant is empty and the promises meaningless. The highest paradox is that God himself demands the sacrifice." Duane Garrett, Rethinking Genesis: The Source and Authorship of the First Book of the Pentateuch, (Grand Rapids, Ml: Baker Book House, 1991), 167.

2"u Justified or not, suffering is always suffering, and explaining it at a human level does not solve anything ... God's answer to suffering is His own suffering . . and deliverances from it." Jacques Doukhan. "The Problem of Suffering," Shabbat Shalom, (December 1994), 13.
} 


\section{Isaac's Marriage, Abraham's Remarriage, and Abraham's Death}

In Genesis Chapter 24, Abraham is well up in years and concerned that his son does not have a heathen wife. So he entreats his trusted sever Eliezer to swear that if he dies he will not get a wife for Isaac from the daughters of the Canaanites. So Eliezer goes to Ur of the Chaldees where the family originated, stops by the city well and prays a prayer that is immediately answered. Rebekah, who is of the linage of Abraham's brother Nahor, is the one who, in answer to his prayer, provides water (24:15-21). After he showers her with gifts and requests lodging, she gets her brother Laban who invites Eliezer home. Eliezer relates his mission to get a wife for Isaac. Laban and Bethuel (Rebecca's father) answered, "The thing comes from the Lord; we cannot speak to you anything bad or good. Look, Rebekah is before you, take her and go, and let her be the wife of your master's son, as the Lord has spoken" (24:50).

Rebekah, with the family's blessing, and her nurse went with Abraham's servant and his men. Isaac immediately receives her, marries her, and is comforted of his grief for his mother (24:62-67).'

Abraham remarries, has six sons and grandchildren but he gives them all gifts and sends them all away. This was Abraham's gift to Isaac; there was no one to share his inheritance $(25: 1-6)$.

Abraham died at a good old age of one hundred seventy-five. Henry Gaubert gives us this epilogue:

Abraham's religious life, which governs the future spiritual evolution of the Chosen People, was marked by three events of great significance: Firstly, the choosing of Abraham by the Lord. Next, the Covenant made between God and

\footnotetext{
' Carol Ochs, Song of the Self: Biblical Spirituality and Human Holiness, (Pittsburgh, PA: Trinity Press International, 1994), 66.
} 
Abraham (and his descendants). Lastly, Abraham's faithfulness. His was integral, unshakable faith, a whole-hearted acceptance of the mission entrusted to him by God. Abraham's earthly life was over. The history of the Chosen People now began.'

One legacy that Abraham left behind is this three step model: Letting go of the past, embracing the present, and planning for the future. (See Glasser's paradigm on page 6). He demonstrated this model the day he entered Canaan until his death (Gen 12:1-4; $25: 5,6)$. From this model one might mistakenly conclude that the process is completed in a few days. But in fact, it can take a number of months or longer and vary from person to person.

'Henri Gaubert, Abraham, Loved by God (New York: The KS Giniger Company, 1968)184. 


\section{EVALUATION}

Seminar:

Presenter:

Date:

On a scale of 12345 (Poor to excellent), rate this seminar and presenter.

$\begin{array}{ccccl}\text { Poor } & \text { Fair } & \text { Good } & \text { Gery } & \\ 1 & 2 & 3 & 4 & 5\end{array}$

Seminar Location

Friday Evening Presentation

Saturday Afternoon Presentation

Sunday Morning Presentation

\section{Materials:}

Grief Handouts

Exercises

Loneliness

Biblical Presentation:

Abraham as a Role Model

Jesus as a Role Model

Presenter:

Presentation

What I liked about the Seminar:

What I did not like about the Seminar:

Recommendations for Seminar Improvement: 


\section{BIBLIOGRAPHY}




\section{BIBLIOGRAPHY}

AARP: Grief, www.aarp.org/families/grief_loss. (July 2005).

Adar, Ziv. The Book of Genesis: An Introduction to the Biblical World. Jerusalem: Magnes Press, 1990.

Alexander, T. Desmond. "Lot's Hospitality: A Clue to His Righteousness." Journal of Biblical Literature 104, no. 2 (1985): 290.

The Anchor Bible Dictionary. Vol. 2. Edited by David Noel Freedman. New York: Doubleday, 1992. 2:101-105.

Attig, Thomas. How We Grieve: Relearning the World. New York: Oxford University Press, 1996.

Bloom, Benjamin S., Thomas Hastings, and George F. Madaus. Handbook on Formative and Summative Evaluation of Student Learning. New York: McGraw-Hill, 1971.

Bork, Paul F. Out of the City, Across the Sands. Washington, DC: Review and Herald, 1982.

Brier, Bob, and Hoyt Hobbs. Daily Life of the Ancient Egyptians. Westport, CT: Greenwood Press, 1999.

Burkett, Delbert. “Two Accounts of Lazarus' Resurrection in John 11." Novum Testamentum 36 (July 1994): 217.

Catholic Forum, www.catholic-forum.com/saints/ps00262.htm. (May 2005).

Cohen, Norman J. Self, Struggle \& Change: Family Conflict Stories in Genesis and Their Healing Insights for Our Lives. Woodstock, VT: Jewish Lights Publishing, 1995.

Cook, Alicia Skinner, and Daniel S. Dworkin. Helping the Bereaved: Therapeutic Interventions for Children, Adolescents, and Adults. New York: Basic Books, 1992.

Corr, Charles A., Clyde M. Nabe, and Donna M. Corr. Death and Dying, Life and Living. $3^{\text {rd }}$ ed. Belmont, CA: Wadsworth/Thomson Learning, 2000. 
Crisler, Clarence, "The Death of Sister White," Pacific Union Record, July 22, 1915.

Dean, William J. Men of the Bible: Abraham, His Life and Times. Chicago: Fleming J. Revell, 1942.

DelBene, Ron, Mary Montgomery, and Herb Montgomery. When I'm Alone: Thoughts and Prayers That Comfort. Nashville, TN: The Upper Room, 1988.

Doka, Kenneth J., and Joyce Davidson. Living with Grief When Illness Is Prolonged. Bristol, PA: Taylor \& Francis, 1997.

Doukhan, Jacques. "The Problem of Suffering." Shabbat Shalom, December 1994, 13-14.

Dumbrell, W. J. "The Covenant with Abraham." The Reformed Theological Review 41 (May-August 1982): 42.

Edwards, Paul. Reincarnation: A Critical Examination. Amherst, NY: Prometheus Books, 1996.

Essex, Keith H. "The Abrahamic Covenant." The Master's Seminary Journal, Vol. 10, no. 2. Fall (1999): 201.

Finley, Mark. Lonely No Longer. Fallbrook, CA: Hart Research Center, 1993.

Fudge, Edward William. The Fire That Consumes the Biblical Case for Conditional Immortality. Carlisle, UK: Paternoster Press, 1994.

Funeral Planning: Everything You Need to Know About Funerals, www.funeralplan.com. (July 2005).

Garrett, Duane. Rethinking Genesis: The Source and Authorship of the First Book of the Pentateuch. Grand Rapids, MI: Baker Book House, 1991.

Gaubert, Henri. Abraham, Loved by God. New York: KS Giniger Company, 1968.

General Conference Ministerial Association. Seventh-day Adventists Believe: A Biblical Exposition of 27 Fundamental Doctrines. Hagerstown, MD: Review and Herald, 1988.

"General and Old Testament Articles Genesis, Exodus, Leviticus." The New Interpreter's Bible. Edited by Nolan B. Harmon. Nashville, TN: Abingdon Press, 1996. 1:600. 
"Genesis to Deuteronomy." Seventh-day Adventist Bible Commentary. Edited by F. D. Nichols. Washington, DC: Review and Herald, 1978. 1: 298, 474-486.

Glasser, William. Reality Therapy: A New Approach to Psychiatry. New York: Harper \& Row, 1965.

Gonzalez, Angel. Abraham, Father of Believers. New York: Herder and Herder, 1967.

Grief Recovery: The Action Program for Moving Beyond Grief, www.grief.net. (July 2005).

Herkert, Bryce M. "Communicating Grief." OMEGA: The Journal of Death and Dying 41 (2000): 93.

Holmes, T. H., and R. H. Rahe. "The Social Requirement Rating Scale." Journal of Psychological Research 2 (1967): 213.

James, John W., and Frank Cherry. The Grief Recovery Handbook: A Step-by-Step Program for Moving Beyond Loss. New York: Harper \& Row, 1988.

James, John W., and Russell Friedman. The Grief Recovery Handbook. New York: HarperCollins, 1988), 11-12.

Kraemer, David. The Meaning of Death in Rabbinic Judaism. New York: Routledge, 2000.

Kubler-Ross, Elisabeth. On Death and Dying. New York: Macmillan, 1966.

Ma'Sumian, Farnaz. Life After Death: A Study of the Afterlife in World Religions. Rockport, MA: Oneworld Publication, 1995.

Manning, Doug. Don't Take My Grief Away: What to Do When You Lose a Loved One. San Francisco, CA: Harper \& Row, 1984.

Means, J. Jeffrey. "Mighty Prophet, Wounded Healer." The Journal of Pastoral Care \& Counseling 56, no. 1 (2002): 46.

Niebuhr, Reinhold, 1934. http://open-mind.org/Serenity.htm, (2/17/2004).

North, James J., Jr. Grief and Loss. http://project-care.org/grief-loss.hmt. (July 7, 2004).

Ochs, Carol. Song of the Self: Biblical Spiritual and Human Holiness. Pittsburgh, PA: Trinity Press, 1994.

Phillips, Frank B. His Robe or Mine? Berrien Springs, MI: Lithotech, 2003. 
Ratzinger, Joseph Cardinal. Catechism of the Catholic Church. $2^{\text {nd }}$ ed. Washington, DC: United States Catholic Conference, 1994.

Reardon, Patrick T. "Sarah Laughed." U.S. Catholic 65, no.1 (January 2000): 43-45.

Sanders, Catherine M. Grief: The Mourning After; Dealing with Adult Bereavement. $2^{\text {nd }}$ ed. New York: John Wiley \& Sons, 1999.

Schneider, Sandra M. "Death in the Community of Eternal Life History, Theology, and Spirituality in John 11." Interpretation 41, no. 1 (1987): 49.

Seventh-day Adventist Encyclopedia. Edited by Don F. Neufeld. Hagerstown, MD: Review and Herald, 1996. 2:693-694.

Streets, Frederick J. “Grief and Glory.” Christian Century, March 1993, 263.

Wansbrough, Henry. Genesis. Doubleday Bible Commentary. New York: Doubleday, 1998.

Westberg, Granger E. Good Grief. Philadelphia, PA: Fortress Press, 1971.

White, Authur L. Ellen G. White: The Early Years 1827-1862. Vol. 1. Hagerstown, MD: Review and Herald, 1986.

. Ellen G. White: Progressive Years 1863-1875. Vol. 2. Hagerstown, MD: Review and Herald, 1986.

. Ellen G. White: The Lonely Years 1876-1891. Vol. 3. Hagerstown, MD: Review and Herald, 1986.

White, Ellen G. "Beware of the Spare Bed." Review and Herald, January 2, 1872. . The Desire of Ages. Mountain View, CA: Pacific Press, 1940. . Life Sketches. Mountain View, CA: Pacific Press, 1915. . Life Sketches: Ancestry, Early Life, Christian Experience and Extensive Labor of James White and Ellen White. Battle Creek, MI: Steam Press of Seventh-day Adventist Publishing Assn., 1888.

. My Life Today. Washington, DC: Review and Herald, 1952.

. Pastoral Ministries. Silver Spring, MD: Ministerial Association of the General Conference of Seventh-day Adventists, 1995. . Patriarchs and Prophets. Mountain View, CA: Pacific Press, 1958. 
. Selected Messages. Book 2. Washington, DC: Review and Herald , 1958.

. The Spirit of Prophecy. Battle Creek, MI: Stream Press, 1877.

. Testimonies for the Church, 9 vols. Mountain View, CA: Pacific Press, 1855-1868.

. Testimonies for the Churches. Vol. 1. Mountain View, CA: Pacific Press, 1948.

. "The Resurrection of Lazarus." Youth Instructor, March 30, 1899, 2.

In Memoriam: A Sketch of the Last Sickness and Death of Elder James White, who died at Battle Creek, Michigan, August 6, 1881, together with the discourse preached at his funeral. Battle Creek, MI: Review \& Herald Press (1881). Pamphlet 168: 46.

Worden, J. William. Grief Counseling and Grief Therapy: A Handbook for the Mental Health Practitioner. $3^{\text {rd }}$ ed. Hove, East Sussex: Brunner-Routledge, 2003.

Yeager, Randolph O. The Renaissance New Testament. Vol. 17. Gretna, LA: Pelican Publishing, 1985.

Yeagley, Larry. Grief Recovery. Charlotte, MI: The author, 1998.

Zondervan Dictionary of Bible Themes: The Accessible and Comprehensive Tool for Topical Studies. Edited by Martin H. Manser. Grand Rapids, MI: Zondervan, 1999. 